\title{
UK Renal Registry 20th Annual Report: Chapter 8 Biochemical Variables in UK Adult Dialysis Patients in 2016: National and Centre-specific Analyses
}

\author{
Rhodri Pyart ${ }^{a}$, Anna Casula ${ }^{a}$, Johann Nicholas ${ }^{b}$, Anne Dawnay $^{c}$

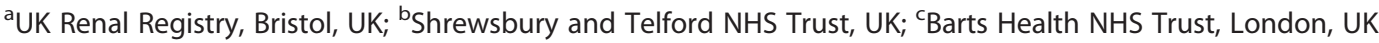

\section{Keywords}

Bicarbonate - Biochemical variables - Calcium - Dialysis . Haemodialysis - Parathyroid hormone - Peritoneal dialysis . Phosphate $\cdot$ Potassium $\cdot$ Quality improvement

\section{Summary}

In 2016

- $59.9 \%$ of haemodialysis (HD) patients and $58.7 \%$ of peritoneal dialysis (PD) patients achieved the Renal Association (RA) audit measure for phosphate $(<1.7 \mathrm{mmol} / \mathrm{L})$.

- $40.1 \%$ of HD and $41.3 \%$ of PD patients had a serum phosphate above the RA audit standard $(\geqslant 1.7 \mathrm{mmol} / \mathrm{L})$.

- Simultaneous control of all three parameters (calcium, phosphate and parathyroid hormone $(\mathrm{PTH})$ ) within current target ranges was achieved by $27.3 \%$ of $\mathrm{HD}$ and $33.2 \%$ of PD patients.

- $78.7 \%$ of HD and $79.7 \%$ of PD patients had adjusted calcium in the recommended target range of 2.2$2.5 \mathrm{mmol} / \mathrm{L}$.

- 55.2\% of HD and $60.3 \%$ of PD patients had phosphate between 1.1-1.7 mmol/L.

- $58.3 \%$ of HD and $65.7 \%$ of PD patients had a serum PTH between 16-72 pmol/L.

- $17.9 \%$ of HD and $13.4 \%$ of PD patients had a serum $\mathrm{PTH}>72 \mathrm{pmol} / \mathrm{L}$.

- $62.2 \%$ of HD and $80.7 \%$ of PD patients achieved the audit measure for bicarbonate (18-24 mmol/L for HD patients and $22-30 \mathrm{mmol} / \mathrm{L}$ for PD patients).

- $84.1 \%$ of HD patients (for whom data were available) had pre-dialysis potassium between 4.0 $6.0 \mathrm{mmol} / \mathrm{L}$.

\section{KARGER}

Fax +41613061234 E-Mail karger@karger.com www.karger.com/nef
This article is licensed under the Creative Commons AttributionNonCommercial-NoDerivatives 4.0 International License (CC BYNC-ND) (http://www.karger.com/Services/OpenAccessLicense). Usage and distribution for commercial purposes as well as any distribution of modified material requires written permission
Rhodri Pyart

UK Renal Registry, Southmead Hospital, Southmead Road,

Bristol, BS10 5NB, UK

Email: renalregistry@renalregistry.nhs.uk 


\section{Introduction}

This chapter analyses the routine biochemistry data of patients on established haemodialysis (HD) and peritoneal dialysis (PD) from all renal centres in the UK in 2016. The UK Renal Registry (UKRR) collects data from all renal centres in England, Wales and Northern Ireland and receives Scottish data via the Scottish Renal Registry. The attainment of biochemistry parameters is compared at a renal centre and national level as well as against national performance measures as set out in the Renal Association (RA) guidelines.

The audit measures listed in table 8.1 applied in 2016 and are obtained from several different RA guidelines [1] which are updated over time:

- CKD-mineral bone disease 2015 guideline [2]

- Haemodialysis 2009 guideline [3] - update due in 2018

- Peritoneal dialysis 2010 guideline [4]

- Cardiovascular disease 2010 guideline [5]
No new guidelines were published during the 2016 calendar year and therefore the same audit standards apply as were used for the 2015 analyses. In 2017, updated KDIGO international chronic kidney disease - mineral bone disorder (CKD-MBD) guidelines were published which have not advocated changes in target biochemical parameters in relation to dialysis patients citing the ongoing lack of strong evidence [6]. They highlight the importance in identifying trends in parameters rather than reacting to isolated measurements and to understand the complex interplay of the variables involved. They advise that clinicians individualise treatment and suggest that changes aimed at improving biochemical parameters could have inadvertent detrimental effects which are more difficult to measure such as in relation to bone mineral density or arterial calcification. In this context, out of range observations (e.g. hyperphosphataemia or PTH below target range) need to be interpreted cautiously as they may relate to different clinical problems or population characteristics.

The most recent RA renal bone disease guidelines offer two audit measures, firstly the proportion of patients with

Table 8.1. Summary of Renal Association audit measures for biochemical variables [1]

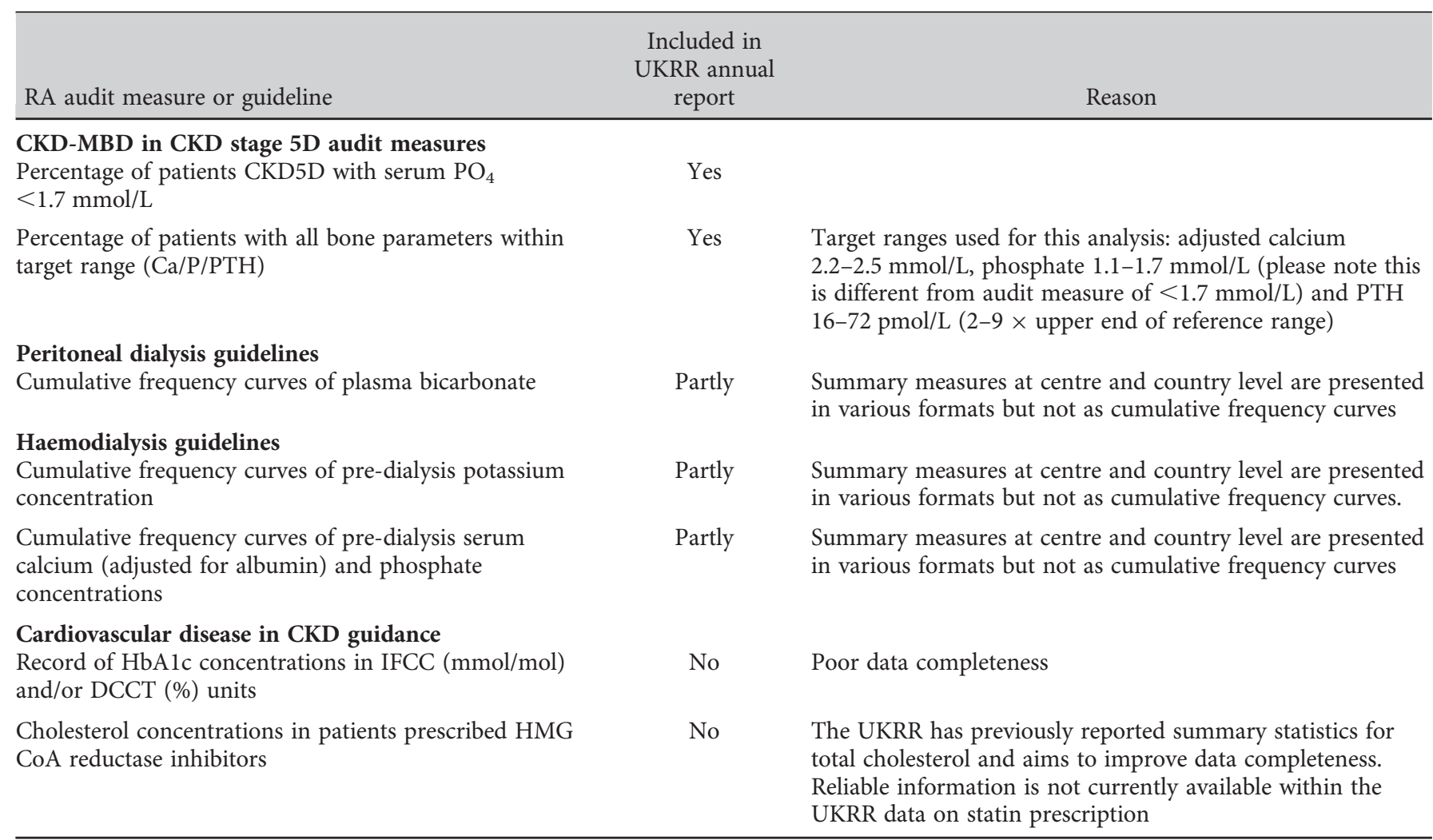

CKD-MBD - chronic kidney disease mineral bone disease; $\mathrm{PO}_{4}$ - phosphate; $\mathrm{Ca}$ - calcium; $\mathrm{P}$ - phosphorous; PTH - parathyroid hormone; HbA1c - glycated haemoglobin; IFCC - International Federation of Clinical Chemistry and Laboratory Medicine; DCCT - Diabetes Control and Complications Trial 
serum phosphate $<1.7 \mathrm{mmol} / \mathrm{L}$ and secondly the proportion of patients with all bone parameters within target range [2]. The target range for phosphate recommended in the guideline is $1.1-1.7 \mathrm{mmol} / \mathrm{L}$ (not $<1.7 \mathrm{mmol} / \mathrm{L}$ as for the phosphate audit measure). Therefore the authors have interpreted the latter audit measure to include this recommended target range for phosphate of 1.1$1.7 \mathrm{mmol} / \mathrm{L}$ which results in different measures of phosphate being used at different points in the chapter and readers should be aware of this when interpreting these results.

For the first time, a sufficient number of centres have returned data in relation to pre-dialysis potassium. The most recent RA haemodialysis guideline recommends an audit measure of cumulative frequency curves of pre-dialysis potassium and includes a target range for pre-dialysis potassium of $4.0-6.0 \mathrm{mmol} / \mathrm{L}$ [3]. There is no recommendation on serum potassium levels in the most recent peritoneal dialysis guidelines [4].

All parameters from haemodialysis patients audited in this report have used data collected mid-week before a 'short-gap' dialysis session in line with recommendations from the bone mineral guidelines as well as the haemodialysis guidelines $[2,3]$.

\section{Methods}

The analyses presented in this chapter relate to biochemical variables in the prevalent dialysis cohort in the UK. The cohort studied were patients prevalent on dialysis treatment on 31 December 2016. Patients receiving dialysis for less than 90 days and those who had changed modality or renal centre in the last 90 days were excluded. HD and PD cohorts were analysed separately. A full definition of the cohort including inclusion and exclusion criteria is available in appendix B (www.renalreg. org/publications-reports/).
The biochemical variables analysed in this chapter were serum phosphate, calcium (adjusted for albumin), parathyroid hormone, bicarbonate and potassium. The method of data collection and validation by the UKRR has been previously described [7]. In brief, for each quarter of 2016 the UKRR extracted biochemical data electronically from clinical information systems in renal centres in England, Wales and Northern Ireland (E,W \& NI). Cambridge renal centre (Addenbrooke's) was unable to submit 2016 data at patient level prior to the UKRR closing the database and only provided summary numbers of patients starting RRT by treatment modality. This centre is therefore excluded from most analyses in this chapter. Scottish centres have only been included in analyses relating to adjusted calcium and phosphate control, with data for their prevalent dialysis cohort being supplied directly by the Scottish Renal Registry. The UKRR does not currently collect data regarding different assay methods mainly because a single dialysis centre may process samples in several different laboratories. The audit measure used for serum phosphate was $<1.7 \mathrm{mmol} / \mathrm{L}$ in both the HD and PD cohorts [2]. However, for the audit measure of composite control of bone parameters it is recommended that all parameters are within the target range and this includes phosphate within the range of 1.1-1.7 $\mathrm{mmol} / \mathrm{L}$, so two different phosphate measures are in use in this chapter. For centres providing adjusted calcium values, these data were analysed directly as it is these values on which clinical decisions within centres are based. For centres providing unadjusted calcium values, the formula provided by each centre (or, if this is not available, a formula in widespread use) was used to calculate adjusted calcium [8]. The audit measure for adjusted calcium depends on the local reference range [2]. For the purposes of these analyses, the UKRR has used the RA guideline standard of adjusted calcium between $2.2-2.5 \mathrm{mmol} / \mathrm{L}$ as the audit measure [2]. There are also a variety of methods and reference ranges in use to measure PTH. To enable some form of comparative audit the UKRR has used two to nine times the median upper limit of the reference range $(8 \mathrm{pmol} / \mathrm{L})$ as the audit measure in line with the RA clinical practice guidelines and KDIGO 2017 guidance, which is unchanged from the previous KDIGO 2009 guidance $[2,6]$. This equates to a PTH range of $16-72 \mathrm{pmol} / \mathrm{L}$. The audit measure used for serum bicarbonate in the HD cohort was 18$24 \mathrm{mmol} / \mathrm{L}$ and in the PD cohort was $22-30 \mathrm{mmol} / \mathrm{L}$ as per the most recent guidelines $[3,4]$. The audit measure for pre-dialysis serum potassium in the $\mathrm{HD}$ cohort uses the latest RA guideline

Table 8.2. Summary of clinical guideline target ranges and conversion factors from SI units

\begin{tabular}{llc}
\hline Biochemical variable & \multicolumn{1}{c}{ Clinical guideline measure } & Conversion factor from SI units \\
\hline Phosphate $^{*}$ & HD patients: $1.1-1.7 \mathrm{mmol} / \mathrm{L}$ & $\mathrm{mg} / \mathrm{dl}=\mathrm{mmol} / \mathrm{L} \times 3.1$ \\
Calcium (adjusted) & PD patients: $1.1-1.7 \mathrm{mmol} / \mathrm{L}$ & $\mathrm{mg} / \mathrm{dl}=\mathrm{mmol} / \mathrm{L} \times 4$ \\
Parathyroid hormone & Normal range (ideally $2.2-2.5 \mathrm{mmol} / \mathrm{L})$ & $\mathrm{ng} / \mathrm{L}=\mathrm{pmol} / \mathrm{L} \times 9.4$ \\
Bicarbonate & $2-9$ times upper limit of normal & $\mathrm{mg} / \mathrm{dl}=\mathrm{mmol} / \mathrm{L} \times 6.1$ \\
& HD patients: $18-24 \mathrm{mmol} / \mathrm{L}$ & $\mathrm{mEq} / \mathrm{L}=\mathrm{mmol} / \mathrm{L}$ \\
\hline
\end{tabular}

${ }^{*}$ There are two measures for phosphate in use: 1 . phosphate clinical audit measure is $<1.7 \mathrm{mmol} / \mathrm{L}$ while 2 . the combined CKD-MBD audit measure assesses all parameters within the target ranges listed in the table which includes phosphate within $1.1-1.7 \mathrm{mmol} / \mathrm{L}$ 
which is $4.0-6.0 \mathrm{mmol} / \mathrm{L}$ [3]. A summary of the current RA audit measures for these variables and conversion factors to SI units are given in table 8.2.

Quarterly values were extracted from the database for the last two quarters for calcium, phosphate, bicarbonate and potassium and the last three quarters for PTH. Patients who did not have these data were excluded from the analyses. Data completeness was analysed at centre and country level. All patients were included in analyses but centres with less than $50 \%$ completeness were excluded from plots and tables showing centre level performance. Data were also excluded from plots and tables when there were fewer than ten patients with data, both at centre or country level. These data were analysed to calculate summary descriptive statistics (maximum, minimum, mean with the corresponding standard deviation, median and interquartile range). Where applicable, the percentage achieving the RA standard or other surrogate clinical performance measure was also calculated.

The simultaneous control of all three components of bone and mineral disorder (BMD) parameters were analysed in combination. The proportion of patients with control of none, one, two or three parameters are presented. For the purpose of these analyses an adjusted calcium between $2.2-2.5 \mathrm{mmol} / \mathrm{L}$, a phosphate level being maintained between 1.1-1.7 mmol/L and a PTH level between two and nine times the upper limit of normal (i.e. $16-72 \mathrm{pmol} / \mathrm{L}$ ), were evaluated in combination.

Centres reported several biochemical variables with different levels of accuracy, leading to problems in comparative evaluation. For example, in the case of serum bicarbonate, data can be submitted as integer values but some centres submit data to one decimal place. All data have been rounded in an attempt to make centres more comparable.

Centres were requested to send pre-dialysis potassium levels for HD patients. Outlying centres were contacted and it was identified that post-dialysis potassium data had inadvertently been submitted and these centres have been excluded from the analysis. However, post-dialysis samples may remain within the analysis for some centres. Future data extracts will aim to ensure that only pre-dialysis results be submitted.
The number preceding the centre name in each figure indicates the percentage of missing data for that centre for that variable. Funnel plot analyses were used to identify outlying centres [9]. The percentage within range for each standard was plotted against centre size along with the upper and lower 95\% and 99.9\% confidence limits. Centres can be identified on these plots by looking up the number of patients treated in each centre in the relevant table and finding this value on the $\mathrm{x}$-axis. Longitudinal analyses were performed for some data to calculate overall changes in achievement of a performance measure annually from 2006 to 2016 and were recalculated for each previous year using the rounding procedure.

All data are presented unadjusted for case-mix.

The data were analysed using SAS 9.3.

Results

Mineral and bone variables

Phosphate

In 2016 the following RA clinical practice guideline regarding phosphate management was applicable:

Guideline 3.2 CKD-MBD: Serum phosphate in dialysis patients

'We suggest that serum phosphate in dialysis patients, measured before a "short-gap" dialysis session in haemodialysis patients, should be maintained between 1.1 and $1.7 \mathrm{mmol} / \mathrm{L}$.' [2]

Audit measure: Percentage of patients CKD5D with serum PO4 $<1.7 \mathrm{mmol} / \mathrm{L}$ [2]

\section{Haemodialysis}

Table 8.3. Summary statistics for serum phosphate in haemodialysis patients in 2016

\begin{tabular}{|c|c|c|c|c|c|c|c|}
\hline Centre & $\begin{array}{c}\% \\
\text { completeness }\end{array}$ & $\begin{array}{c}\text { Patients with data } \\
\qquad N\end{array}$ & Mean & $\mathrm{SD}$ & Median & $\begin{array}{l}\text { Lower } \\
\text { quartile }\end{array}$ & $\begin{array}{l}\text { Upper } \\
\text { quartile }\end{array}$ \\
\hline \multicolumn{8}{|l|}{ England } \\
\hline B Heart & 100.0 & 373 & 1.8 & 0.6 & 1.7 & 1.4 & 2.0 \\
\hline B QEH & 99.6 & 934 & 1.5 & 0.4 & 1.5 & 1.2 & 1.8 \\
\hline Basldn & 98.0 & 147 & 1.6 & 0.5 & 1.6 & 1.3 & 1.9 \\
\hline Bradfd & 99.1 & 226 & 1.5 & 0.5 & 1.5 & 1.2 & 1.8 \\
\hline Brightn & 99.8 & 418 & 1.7 & 0.6 & 1.6 & 1.3 & 2.0 \\
\hline Bristol & 100.0 & 470 & 1.6 & 0.5 & 1.6 & 1.3 & 2.0 \\
\hline \multicolumn{8}{|l|}{ Camb* } \\
\hline Carlis & 100.0 & 88 & 1.6 & 0.5 & 1.5 & 1.3 & 1.9 \\
\hline Carsh & 99.6 & 771 & 1.6 & 0.5 & 1.5 & 1.2 & 1.8 \\
\hline Chelms & 100.0 & 118 & 1.6 & 0.5 & 1.6 & 1.3 & 1.8 \\
\hline Colchr & 83.6 & 92 & 1.5 & 0.4 & 1.4 & 1.2 & 1.7 \\
\hline Covnt & 99.7 & 345 & 1.7 & 0.5 & 1.6 & 1.3 & 1.9 \\
\hline Derby & 100.0 & 227 & 1.5 & 0.5 & 1.5 & 1.2 & 1.8 \\
\hline Donc & 100.0 & 177 & 1.6 & 0.4 & 1.6 & 1.3 & 1.9 \\
\hline
\end{tabular}


Table 8.3. Continued

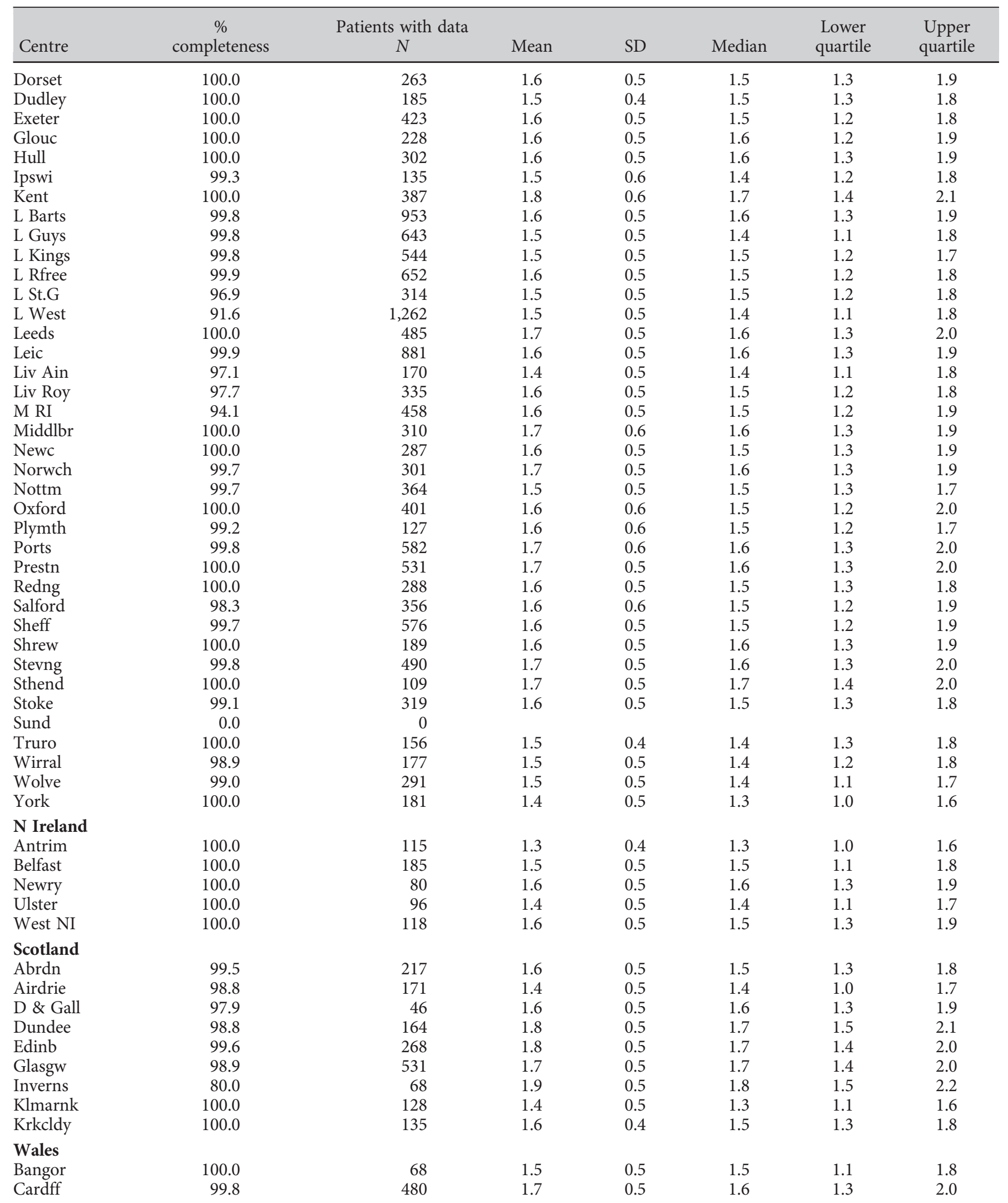


Table 8.3. Continued

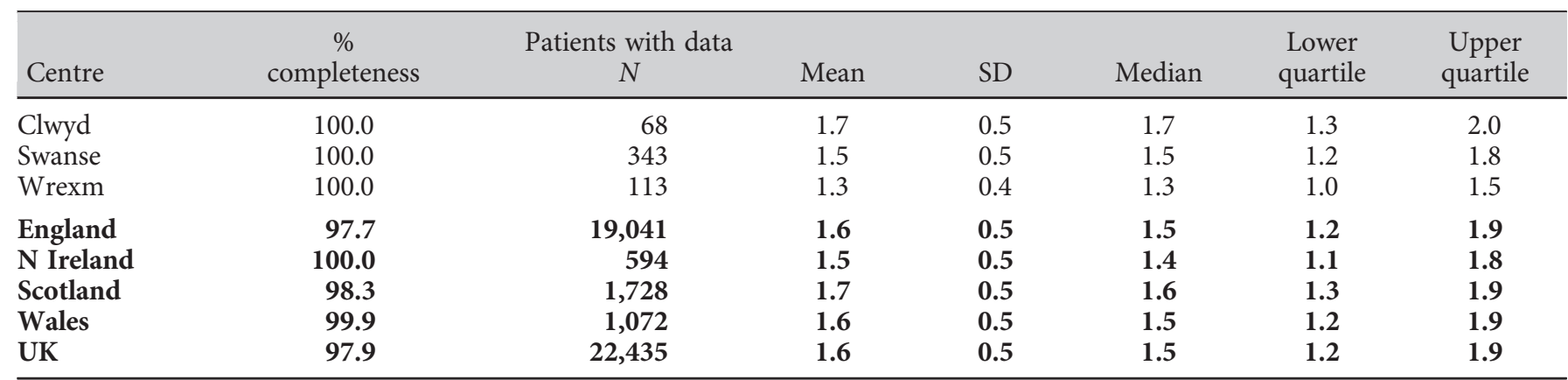

Blank cells: centres excluded from analysis due to low patient numbers or poor data completeness

* Cambridge renal centre was unable to submit serum phosphate data for 2016

Table 8.4. Percentage of haemodialysis patients with serum phosphate below and equal to or above $1.7 \mathrm{mmol} / \mathrm{L}$, as specified in the RA audit measure, by centre in 2016

\begin{tabular}{|c|c|c|c|c|c|c|c|c|}
\hline Centre & $N$ & $\begin{array}{c}\% \text { phos } \\
<1.7 \mathrm{mmol} / \mathrm{L}\end{array}$ & $\begin{array}{c}\text { Lower } 95 \% \\
\text { CI }\end{array}$ & $\begin{array}{c}\text { Upper } 95 \% \\
\text { CI }\end{array}$ & $\begin{array}{c}\text { \% phos } \\
\geqslant 1.7 \mathrm{mmol} / \mathrm{L}\end{array}$ & $\begin{array}{l}\text { Change in \% } \\
<1.7 \mathrm{mmol} / \mathrm{L} \\
\text { from } 2015\end{array}$ & $\begin{array}{l}95 \% \text { LCL } \\
\text { change }\end{array}$ & $\begin{array}{l}95 \% \text { UCL } \\
\text { change }\end{array}$ \\
\hline \multicolumn{9}{|l|}{ England } \\
\hline B Heart & 373 & 44.2 & 39.3 & 49.3 & 55.8 & -13.9 & -20.9 & -6.9 \\
\hline B QEH & 934 & 65.9 & 62.7 & 68.8 & 34.2 & -5.6 & -9.9 & -1.4 \\
\hline Basldn & 147 & 54.4 & 46.3 & 62.3 & 45.6 & -12.0 & -23.0 & -1.0 \\
\hline Bradfd & 226 & 66.4 & 60.0 & 72.2 & 33.6 & -2.3 & -11.0 & 6.4 \\
\hline Brightn & 418 & 53.4 & 48.6 & 58.1 & 46.7 & -3.5 & -10.4 & 3.3 \\
\hline Bristol & 470 & 54.0 & 49.5 & 58.5 & 46.0 & -8.7 & -15.0 & -2.5 \\
\hline Carlis & 88 & 56.8 & 46.3 & 66.7 & 43.2 & -11.2 & -26.0 & 3.6 \\
\hline Carsh & 771 & 61.6 & 58.1 & 65.0 & 38.4 & -5.6 & -10.4 & -0.8 \\
\hline Chelms & 118 & 64.4 & 55.4 & 72.5 & 35.6 & 4.3 & -7.6 & 16.2 \\
\hline Colchr & 92 & 75.0 & 65.2 & 82.8 & 25.0 & 4.3 & -8.1 & 16.6 \\
\hline Covnt & 345 & 53.3 & 48.1 & 58.5 & 46.7 & -3.8 & -11.2 & 3.7 \\
\hline Derby & 227 & 64.8 & 58.3 & 70.7 & 35.2 & -3.6 & -12.3 & 5.2 \\
\hline Donc & 177 & 55.4 & 48.0 & 62.5 & 44.6 & -8.4 & -18.8 & 2.0 \\
\hline Dorset & 263 & 59.7 & 53.7 & 65.5 & 40.3 & -14.8 & -22.7 & -7.0 \\
\hline Dudley & 185 & 68.1 & 61.1 & 74.4 & 31.9 & -0.5 & -10.4 & 9.4 \\
\hline Exeter & 423 & 63.6 & 58.9 & 68.0 & 36.4 & -3.8 & -10.3 & 2.7 \\
\hline Glouc & 228 & 57.9 & 51.4 & 64.1 & 42.1 & -3.4 & -12.5 & 5.7 \\
\hline Hull & 302 & 55.0 & 49.3 & 60.5 & 45.0 & -7.2 & -14.9 & 0.5 \\
\hline Ipswi & 135 & 63.7 & 55.3 & 71.4 & 36.3 & -10.7 & -21.8 & 0.3 \\
\hline Kent & 387 & 47.3 & 42.4 & 52.3 & 52.7 & -5.5 & -12.5 & 1.5 \\
\hline L Barts & 953 & 56.2 & 53.1 & 59.4 & 43.8 & -4.2 & -8.7 & 0.2 \\
\hline L Guys & 643 & 67.7 & 63.9 & 71.2 & 32.4 & 2.3 & -2.9 & 7.5 \\
\hline L Kings & 544 & 66.2 & 62.1 & 70.0 & 33.8 & -7.9 & -13.4 & -2.4 \\
\hline L Rfree & 652 & 62.9 & 59.1 & 66.5 & 37.1 & -3.0 & -8.2 & 2.1 \\
\hline L St.G & 314 & 65.9 & 60.5 & 71.0 & 34.1 & -5.2 & -12.5 & 2.1 \\
\hline L West & 1,262 & 67.1 & 64.5 & 69.7 & 32.9 & -2.1 & -5.8 & 1.5 \\
\hline Leeds & 485 & 53.2 & 48.7 & 57.6 & 46.8 & -7.4 & -13.6 & -1.1 \\
\hline Leic & 881 & 57.8 & 54.5 & 61.0 & 42.2 & -2.5 & -7.2 & 2.1 \\
\hline Liv Ain & 170 & 64.7 & 57.2 & 71.5 & 35.3 & -13.1 & -22.8 & -3.3 \\
\hline Liv Roy & 335 & 64.8 & 59.5 & 69.7 & 35.2 & 1.2 & -5.9 & 8.4 \\
\hline M RI* & 458 & 60.9 & 56.4 & 65.3 & 39.1 & -1.6 & -8.0 & 4.7 \\
\hline
\end{tabular}


Table 8.4. Continued

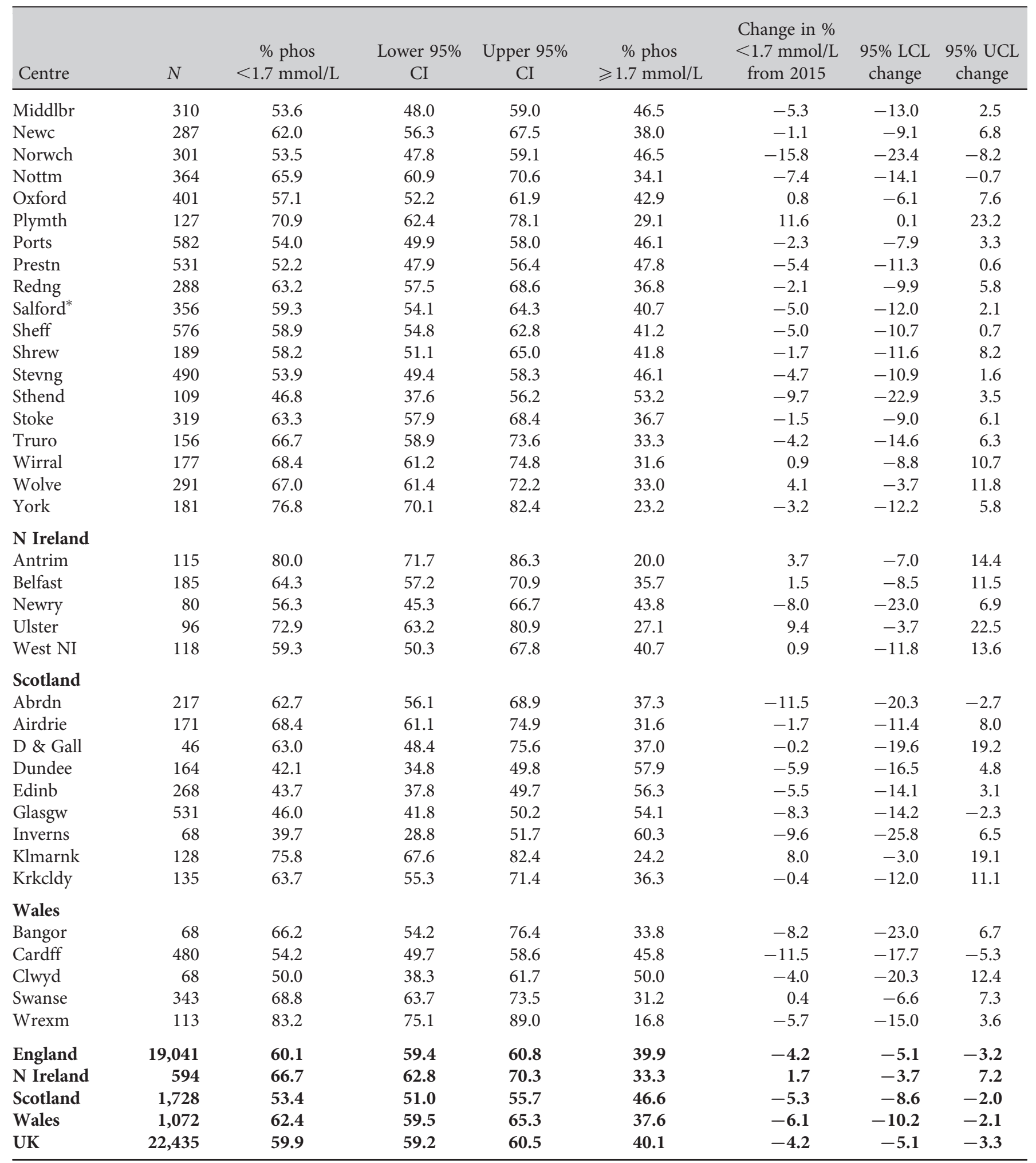

Centres missing from the table were excluded from analysis due to low patient numbers or poor data completeness

*Salford and Manchester RI have been involved in the SPIRiT study; an RCT comparing low phosphate control (0.8-1.4 mmol/L) with high phosphate control (1.8-2.4 mmol/L); HD patients only were recruited 


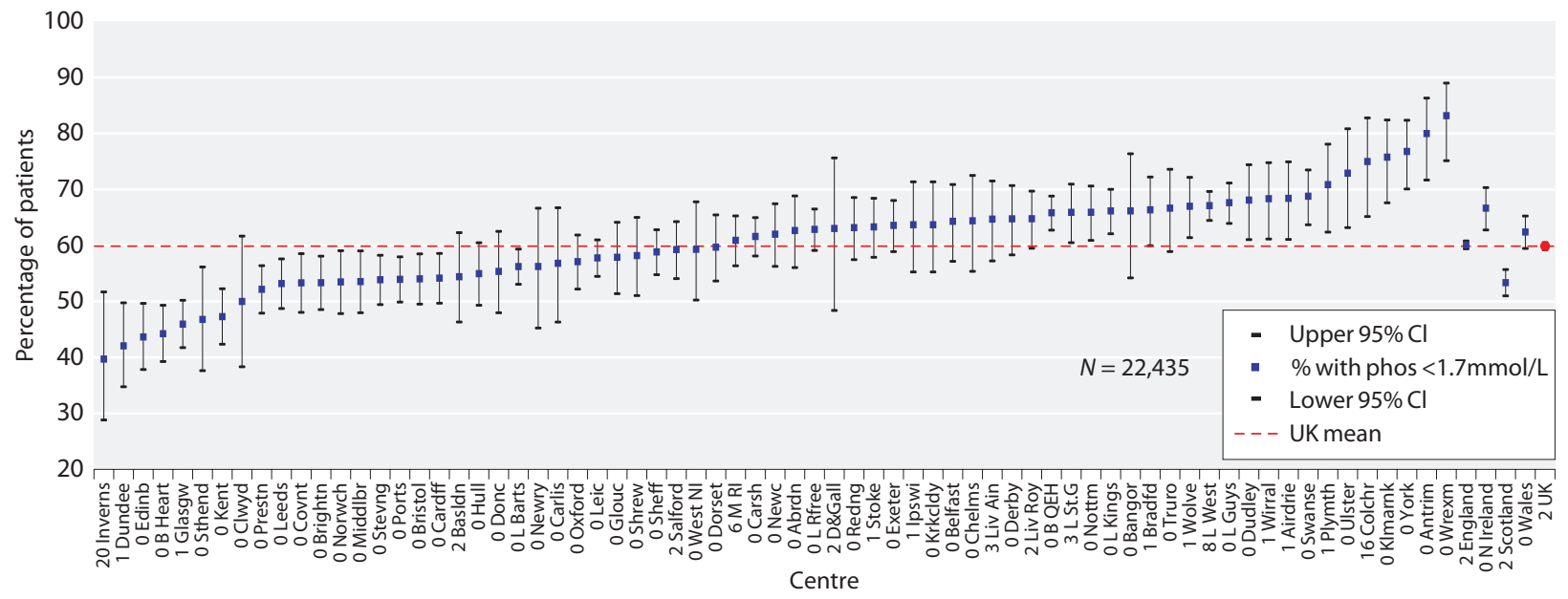

Fig. 8.1. Percentage of haemodialysis patients with serum phosphate below $1.7 \mathrm{mmol} / \mathrm{L}$ as specified by the RA audit measure, by centre in 2016

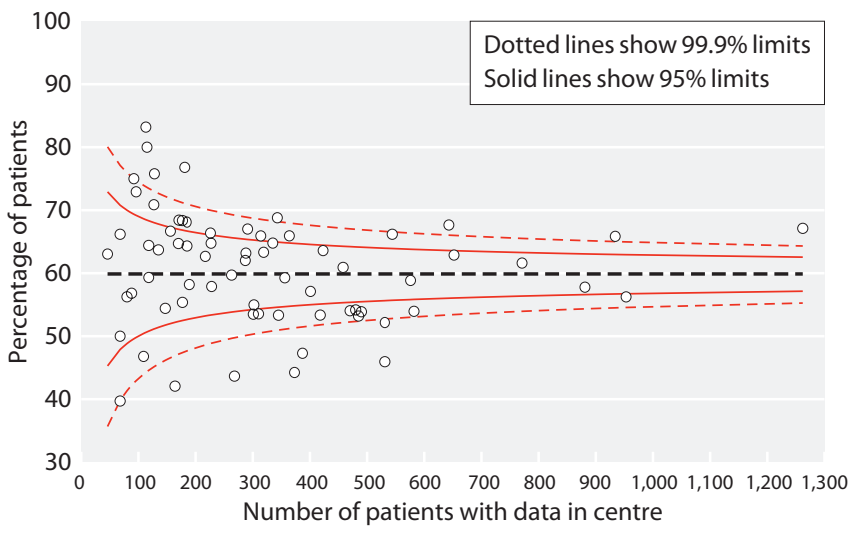

Fig. 8.2. Funnel plot of percentage of haemodialysis patients with serum phosphate below $1.7 \mathrm{mmol} / \mathrm{L}$ as specified by the $\mathrm{RA}$ clinical audit measure, by centre in 2016

\section{Peritoneal dialysis}

Table 8.5. Summary statistics for phosphate in peritoneal dialysis patients in 2016

\begin{tabular}{|c|c|c|c|c|c|c|c|}
\hline Centre & $\begin{array}{c}\% \\
\text { completeness }\end{array}$ & $\begin{array}{c}\text { Patients with data } \\
\qquad N\end{array}$ & Mean & SD & Median & $\begin{array}{l}\text { Lower } \\
\text { quartile }\end{array}$ & $\begin{array}{l}\text { Upper } \\
\text { quartile }\end{array}$ \\
\hline \multicolumn{8}{|l|}{ England } \\
\hline B Heart & 100.0 & 72 & 1.8 & 0.5 & 1.8 & 1.5 & 2.2 \\
\hline B QEH & 100.0 & 125 & 1.6 & 0.5 & 1.6 & 1.3 & 1.8 \\
\hline Basldn & 100.0 & 30 & 1.6 & 0.4 & 1.5 & 1.3 & 1.8 \\
\hline Bradfd & 100.0 & 22 & 1.7 & 0.5 & 1.8 & 1.3 & 2.1 \\
\hline Brightn & 100.0 & 56 & 1.6 & 0.4 & 1.6 & 1.4 & 1.9 \\
\hline Bristol & 100.0 & 42 & 1.7 & 0.5 & 1.6 & 1.4 & 1.9 \\
\hline \multicolumn{8}{|l|}{$\mathrm{Camb}^{\mathrm{a}}$} \\
\hline Carlis & 96.8 & 30 & 1.6 & 0.4 & 1.6 & 1.3 & 1.9 \\
\hline Carsh & 92.1 & 93 & 1.6 & 0.4 & 1.5 & 1.3 & 1.9 \\
\hline Chelms & 88.9 & 24 & 1.7 & 0.6 & 1.5 & 1.3 & 1.9 \\
\hline \multicolumn{8}{|l|}{ Colchr ${ }^{\mathrm{b}}$} \\
\hline Covnt & 96.6 & 57 & 1.5 & 0.4 & 1.5 & 1.2 & 1.7 \\
\hline Derby & 100.0 & 71 & 1.5 & 0.4 & 1.4 & 1.2 & 1.6 \\
\hline Donc & 100.0 & 25 & 1.5 & 0.3 & 1.5 & 1.3 & 1.6 \\
\hline
\end{tabular}


Table 8.5. Continued

\begin{tabular}{|c|c|c|c|c|c|c|c|}
\hline Centre & $\begin{array}{c}\% \\
\text { completeness }\end{array}$ & $\begin{array}{c}\text { Patients with data } \\
\qquad N\end{array}$ & Mean & SD & Median & $\begin{array}{l}\text { Lower } \\
\text { quartile }\end{array}$ & $\begin{array}{l}\text { Upper } \\
\text { quartile }\end{array}$ \\
\hline Dorset & 100.0 & 33 & 1.4 & 0.4 & 1.3 & 1.2 & 1.6 \\
\hline Exeter & 100.0 & 73 & 1.6 & 0.5 & 1.6 & 1.2 & 1.8 \\
\hline Glouc & 97.0 & 32 & 1.6 & 0.4 & 1.6 & 1.2 & 1.8 \\
\hline Hull & 100.0 & 61 & 1.6 & 0.4 & 1.6 & 1.4 & 1.9 \\
\hline L Barts & 97.8 & 175 & 1.6 & 0.4 & 1.6 & 1.3 & 1.9 \\
\hline L Guys & 100.0 & 32 & 1.7 & 0.4 & 1.7 & 1.4 & 1.8 \\
\hline L Kings & 100.0 & 75 & 1.6 & 0.4 & 1.5 & 1.3 & 1.8 \\
\hline L Rfree & 97.8 & 135 & 1.6 & 0.4 & 1.5 & 1.4 & 1.8 \\
\hline L St.G & 97.3 & 36 & 1.6 & 0.4 & 1.6 & 1.3 & 1.9 \\
\hline Liv Roy & 98.4 & 63 & 1.4 & 0.4 & 1.3 & 1.2 & 1.7 \\
\hline M RI & 98.0 & 48 & 1.6 & 0.5 & 1.6 & 1.3 & 2.0 \\
\hline Middlbr & 100.0 & 22 & 1.8 & 0.4 & 1.7 & 1.5 & 2.1 \\
\hline Newc & 100.0 & 46 & 1.7 & 0.5 & 1.7 & 1.5 & 2.0 \\
\hline Norwch & 100.0 & 41 & 1.7 & 0.5 & 1.6 & 1.4 & 1.8 \\
\hline Nottm & 100.0 & 67 & 1.6 & 0.4 & 1.6 & 1.3 & 1.8 \\
\hline Oxford & 100.0 & 80 & 1.7 & 0.5 & 1.6 & 1.4 & 1.8 \\
\hline Plymth & 93.6 & 29 & 1.5 & 0.4 & 1.4 & 1.3 & 1.8 \\
\hline Ports & 95.5 & 64 & 1.8 & 0.5 & 1.7 & 1.5 & 2.1 \\
\hline Prestn & 100.0 & 35 & 1.6 & 0.4 & 1.5 & 1.3 & 1.9 \\
\hline Redng & 100.0 & 44 & 1.7 & 0.4 & 1.6 & 1.4 & 1.9 \\
\hline Salford & 98.9 & 89 & 1.7 & 0.5 & 1.6 & 1.4 & 2.0 \\
\hline Wolve & 92.2 & 59 & 1.6 & 0.4 & 1.6 & 1.3 & 1.8 \\
\hline York & 100.0 & 27 & 1.5 & 0.4 & 1.5 & 1.1 & 1.6 \\
\hline \multicolumn{8}{|l|}{ N Ireland } \\
\hline Antrim & 100.0 & 14 & 1.4 & 0.3 & 1.4 & 1.2 & 1.5 \\
\hline Belfast & 100.0 & 22 & 1.6 & 0.4 & 1.5 & 1.3 & 1.9 \\
\hline Newry & 100.0 & 19 & 1.5 & 0.3 & 1.4 & 1.2 & 1.8 \\
\hline Ulster & 100.0 & 5 & & & & & \\
\hline West NI & 100.0 & 9 & & & & & \\
\hline \multicolumn{8}{|l|}{ Scotland } \\
\hline Abrdn & 100.0 & 19 & 1.7 & 0.5 & 1.6 & 1.3 & 2.1 \\
\hline Airdrie & 95.2 & 20 & 1.4 & 0.3 & 1.4 & 1.3 & 1.6 \\
\hline D\&Gall & 100.0 & 10 & 1.6 & 0.3 & 1.6 & 1.4 & 2.0 \\
\hline Dundee & 100.0 & 13 & 1.7 & 0.3 & 1.7 & 1.4 & 1.9 \\
\hline Edinb & 90.3 & 28 & 1.9 & 0.6 & 1.7 & 1.4 & 2.1 \\
\hline Glasgw & 97.7 & 42 & 1.6 & 0.3 & 1.6 & 1.4 & 1.8 \\
\hline Inverns & 33.3 & 3 & & & & & \\
\hline Klmarnk & 96.4 & 27 & 1.7 & 0.4 & 1.6 & 1.4 & 1.9 \\
\hline Krkcldy & 100.0 & 15 & 1.7 & 0.5 & 1.6 & 1.4 & 1.8 \\
\hline
\end{tabular}


Table 8.5. Continued

\begin{tabular}{|c|c|c|c|c|c|c|c|}
\hline Centre & $\begin{array}{c}\% \\
\text { completeness }\end{array}$ & $\begin{array}{c}\text { Patients with data } \\
\qquad N\end{array}$ & Mean & SD & Median & $\begin{array}{l}\text { Lower } \\
\text { quartile }\end{array}$ & $\begin{array}{l}\text { Upper } \\
\text { quartile }\end{array}$ \\
\hline \multicolumn{8}{|l|}{ Wales } \\
\hline Cardff & 95.5 & 64 & 1.7 & 0.5 & 1.6 & 1.4 & 1.9 \\
\hline Clwyd & 100.0 & 14 & 1.5 & 0.5 & 1.5 & 1.2 & 1.9 \\
\hline Swanse & 100.0 & 58 & 1.7 & 0.5 & 1.6 & 1.3 & 2.0 \\
\hline England & 98.1 & 2,574 & 1.6 & 0.4 & 1.6 & 1.3 & 1.9 \\
\hline N Ireland & 100.0 & 69 & 1.5 & 0.3 & 1.4 & 1.3 & 1.8 \\
\hline Scotland & 93.7 & 177 & 1.7 & 0.4 & 1.6 & 1.4 & 1.9 \\
\hline Wales & 98.4 & 179 & 1.6 & 0.5 & 1.6 & 1.3 & 1.9 \\
\hline UK & 97.9 & 2,999 & 1.6 & 0.4 & 1.6 & 1.3 & 1.9 \\
\hline
\end{tabular}

Blank cells - centres excluded from analysis due to low patient numbers or poor data completeness

${ }^{a}$ Cambridge renal centre was unable to submit serum phosphate data for 2016

${ }^{\mathrm{b}}$ Colchester - no PD patients

Table 8.6. Percentage of peritoneal dialysis patients with serum phosphate below and equal to or above $1.7 \mathrm{mmol} / \mathrm{L}$ as specified in the RA audit measure in 2016

\begin{tabular}{|c|c|c|c|c|c|c|c|c|}
\hline Centre & $N$ & $\begin{array}{c}\% \text { phos } \\
<1.7 \mathrm{mmol} / \mathrm{L}\end{array}$ & $\begin{array}{c}\text { Lower } 95 \% \\
\text { CI }\end{array}$ & $\begin{array}{c}\text { Upper } 95 \% \\
\text { CI }\end{array}$ & $\begin{array}{l}\% \text { with phos } \\
\geqslant 1.7 \mathrm{mmol} / \mathrm{L}\end{array}$ & $\begin{array}{l}\text { Change in \% } \\
<1.7 \mathrm{mmol} / \mathrm{L} \\
\text { from } 2015\end{array}$ & $\begin{array}{l}95 \% \text { LCL } \\
\text { change }\end{array}$ & $\begin{array}{l}95 \% \text { UCL } \\
\text { change }\end{array}$ \\
\hline \multicolumn{9}{|l|}{ England } \\
\hline B Heart & 72 & 36.1 & 25.9 & 47.8 & 63.9 & -13.9 & -32.9 & 5.2 \\
\hline $\mathrm{B} \mathrm{QEH}$ & 125 & 60.0 & 51.2 & 68.2 & 40.0 & 1.3 & -11.0 & 13.6 \\
\hline Basldn & 30 & 56.7 & 38.8 & 72.9 & 43.3 & 4.8 & -21.1 & 30.7 \\
\hline Bradfd & 22 & 45.5 & 26.5 & 65.9 & 54.6 & 9.7 & -22.9 & 42.3 \\
\hline Carlis & 30 & 63.3 & 45.1 & 78.4 & 36.7 & 6.7 & -18.1 & 31.4 \\
\hline Carsh & 93 & 61.3 & 51.1 & 70.6 & 38.7 & 2.6 & -11.5 & 16.7 \\
\hline Chelms & 24 & 62.5 & 42.2 & 79.2 & 37.5 & 8.0 & -20.5 & 36.4 \\
\hline Covnt & 57 & 64.9 & 51.8 & 76.1 & 35.1 & -13.9 & -29.7 & 2.0 \\
\hline Derby & 71 & 77.5 & 66.3 & 85.7 & 22.5 & 7.6 & -6.7 & 21.9 \\
\hline Donc & 25 & 80.0 & 60.0 & 91.4 & 20.0 & 13.3 & -13.5 & 40.2 \\
\hline Hull & 61 & 50.8 & 38.5 & 63.1 & 49.2 & -5.4 & -22.9 & 12.0 \\
\hline Ipswi & 32 & 75.0 & 57.4 & 87.0 & 25.0 & 8.3 & -14.9 & 31.6 \\
\hline Kent & 42 & 78.6 & 63.7 & 88.5 & 21.4 & 10.1 & -7.5 & 27.6 \\
\hline L Barts & 175 & 55.4 & 48.0 & 62.6 & 44.6 & -7.1 & -17.4 & 3.1 \\
\hline L Guys & 32 & 43.8 & 27.9 & 61.0 & 56.3 & -18.3 & -43.0 & 6.3 \\
\hline L Kings & 75 & 68.0 & 56.7 & 77.5 & 32.0 & 10.5 & -4.6 & 25.6 \\
\hline L Rfree & 135 & 62.2 & 53.8 & 70.0 & 37.8 & 5.1 & -6.7 & 16.8 \\
\hline L St.G & 36 & 52.8 & 36.8 & 68.3 & 47.2 & -12.3 & -34.0 & 9.3 \\
\hline L West & 77 & 58.4 & 47.2 & 68.9 & 41.6 & -12.7 & -29.2 & 3.8 \\
\hline Leeds & 36 & 47.2 & 31.7 & 63.3 & 52.8 & 1.2 & -20.2 & 22.6 \\
\hline Leic & 69 & 69.6 & 57.8 & 79.2 & 30.4 & 7.5 & -7.1 & 22.1 \\
\hline Liv Ain & 23 & 43.5 & 25.2 & 63.7 & 56.5 & -19.5 & -46.7 & 7.8 \\
\hline Liv Roy & 63 & 74.6 & 62.5 & 83.8 & 25.4 & 18.9 & 2.4 & 35.3 \\
\hline
\end{tabular}


Table 8.6. Continued

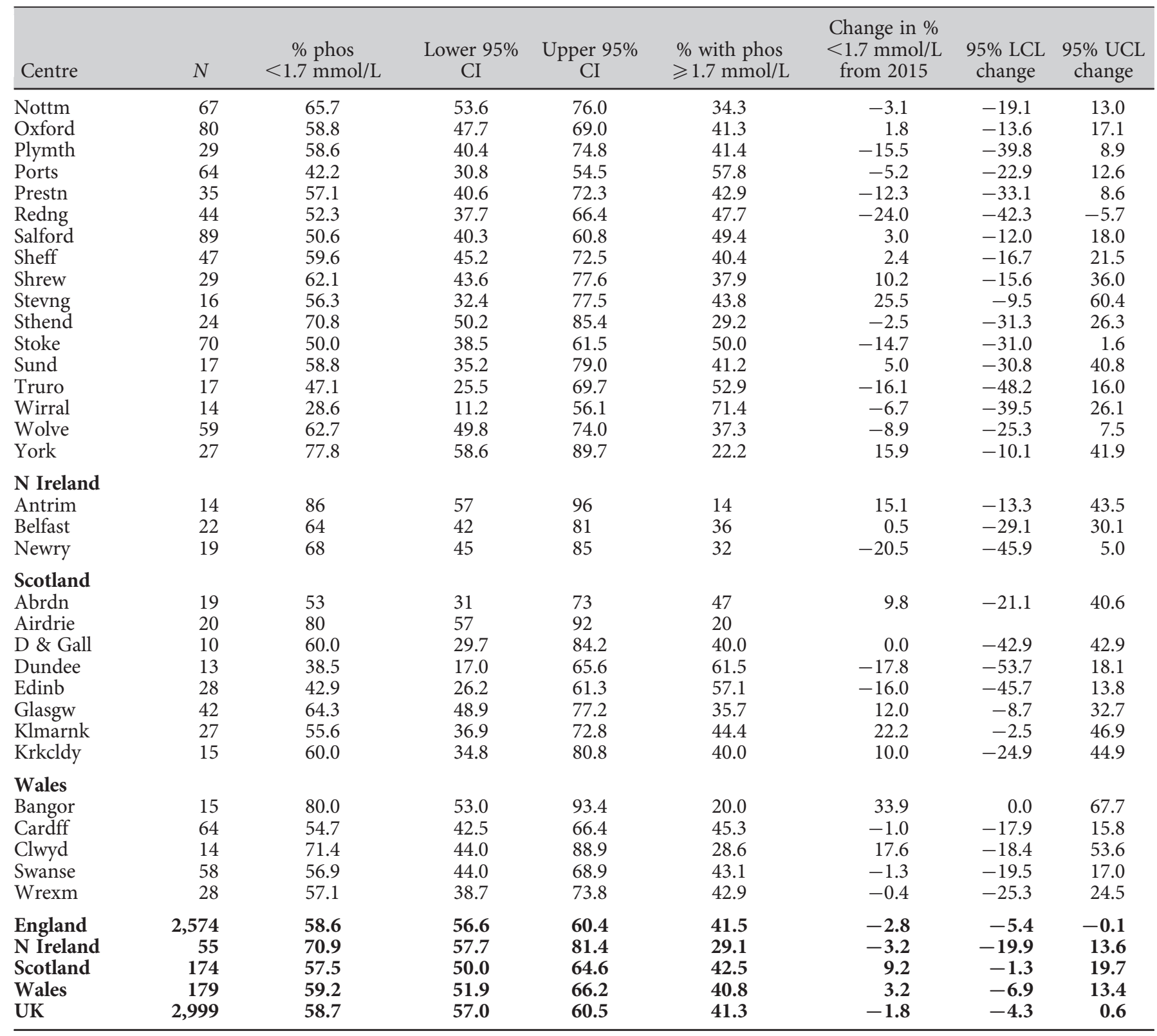

Centres missing from the table were excluded from analysis due to low patient numbers, poor data completeness or no patients on PD Blank cells indicate no data for 2015

Overall, data from 22,435 $\mathrm{HD}$ and 2,999 PD patients across the UK were included in the analyses of serum phosphate in 2016. The overall data completeness for serum phosphate across the UK was $97.9 \%$ for both HD and PD patients, with some variation between centres (tables 8.3, 8.5). HD centre returns were all $>90 \%$, except Cambridge and Sunderland at 0\%, and Colchester and Inverness with completeness between $80-85 \%$. For PD patients, Cambridge also returned no data and only two other centres (Chelmsford and Inverness) returned less than $90 \%$ data, compared with five centres in the previous audit.

The individual centre means and standard deviations are shown in tables 8.3 and 8.5 for $\mathrm{HD}$ and $\mathrm{PD}$ patients respectively.

For those receiving HD, 59.9\% of patients achieved a phosphate level below $1.7 \mathrm{mmol} / \mathrm{L}$, the audit measure specified by the RA, and for those on PD this was 


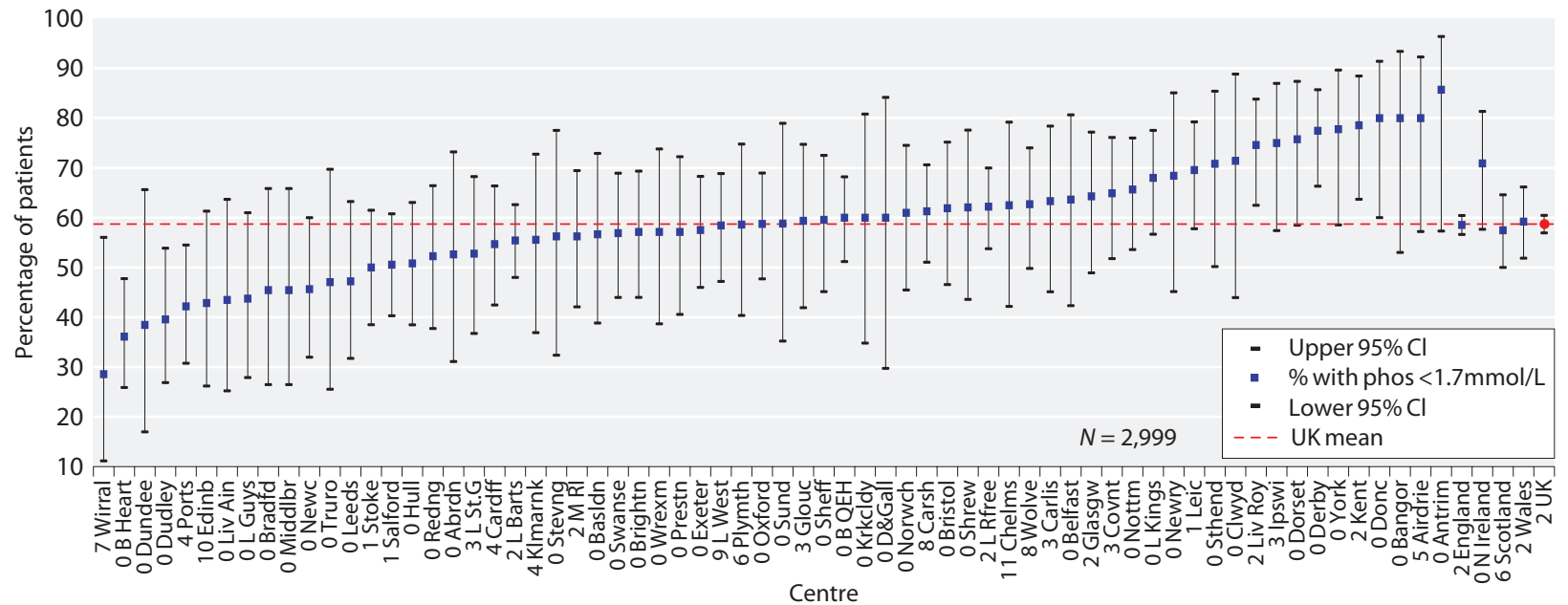

Fig. 8.3. Percentage of peritoneal dialysis patients with serum phosphate below $1.7 \mathrm{mmol} / \mathrm{L}$ as specified by the RA audit measure, by centre in 2016

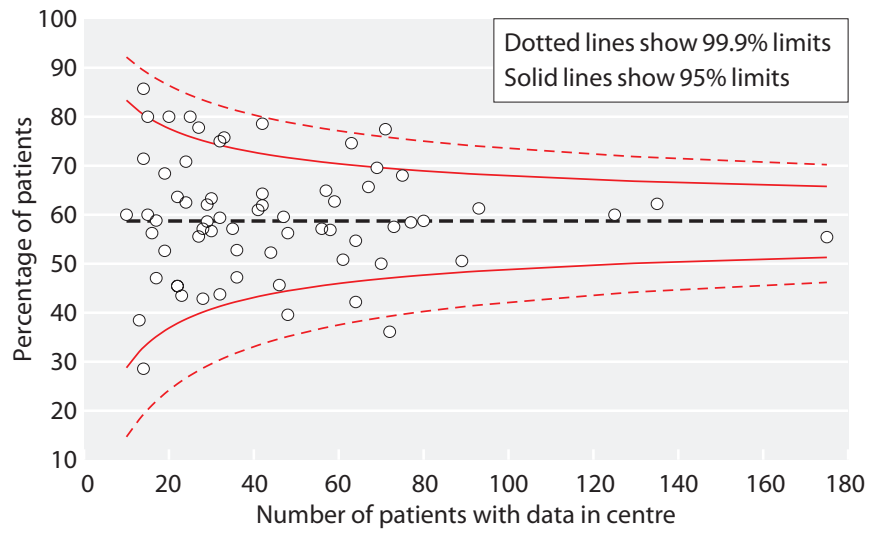

Fig. 8.4. Funnel plot of percentage of peritoneal dialysis patients with phosphate below $1.7 \mathrm{mmol} / \mathrm{L}$ as specified by the RA clinical audit measure, by centre in 2016
$58.7 \%$ (tables $8.4,8.6$ ). In 2015, the equivalent figures were $64.1 \%$ and $60.5 \%$ respectively.

There was inter-centre variation in the proportion of patients below and equal to or above the phosphate target specified by the clinical performance audit measure. The majority of centres saw a fall in the proportion of $\mathrm{HD}$ patients attaining the phosphate target (figures 8.1-8.4, tables 8.4, 8.6).

Funnel plots for HD patients with controlled phosphataemia $(<1.7 \mathrm{mmol} / \mathrm{L})$, show a number of centres attaining this standard in a significantly high proportion of patients: Antrim, Birmingham QEH, Kilmarnock, London Guys, London West, Swansea, Wrexham and York. All these centres achieved above the 99.9\% upper confidence interval following correction for centre size.

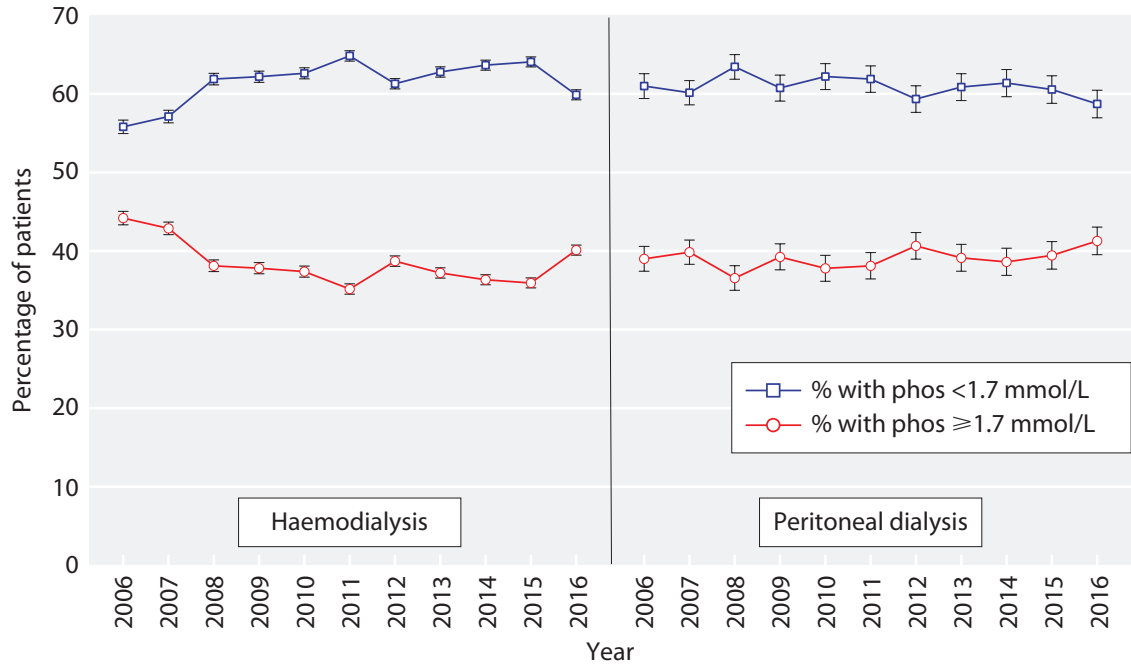

Fig. 8.5. Longitudinal change in percentage of patients with phosphate below and equal to or above $1.7 \mathrm{mmol} / \mathrm{L}$, as specified by the RA clinical audit measure, by dialysis modality 2006-2016 
In addition, a number of centres had achieved the serum phosphate control standard in a lower than expected proportion of patients (being below the lower 99.9\% confidence interval): Birmingham Heartlands, Dundee, Edinburgh, Glasgow, Inverness, Kent and Preston (figure 8.2).

Funnel plots for PD patients indicated that the control of phosphate levels were similar in all centres. Only two significant outliers were identified, Birmingham Heartlands and Derby, achieving the serum phosphate control standard respectively in a lower and in a higher than expected proportion of PD patients (figure 8.4).

Longitudinal analysis demonstrates that the proportion of HD and PD patients with hyperphosphataemia had seen modest improvement over the last decade however this proportion has increased in both modalities this year (figure 8.5). Data showing the performance of centres in attaining phosphate control within the guideline target range (1.1-1.7 mmol/L) can be found in appendix 1 of this chapter (rather than the audit measure of $<1.7 \mathrm{mmol} / \mathrm{L}$ presented here).

Simultaneous control of adjusted calcium, phosphate and $\mathrm{PTH}$ in preventing severe hyperparathyroidism

In 2016 the following RA audit measure for combined biochemical control applied:

'Percentage of patients with all bone parameters within target range (Calcium/Phosphate/PTH)' [2]
The RA guideline does not explicitly outline the target ranges to be used in the audit measure itself therefore the authors have interpreted this to include the target ranges suggested for each biochemical measure in the guideline. Therefore the combined audit measure comprised the following: phosphate $1.1-1.7 \mathrm{mmol} / \mathrm{L}$, adjusted calcium $2.2-2.5 \mathrm{mmol} / \mathrm{L}$ and PTH $16-72 \mathrm{pmol} / \mathrm{L}$. Please note this phosphate measure is discrepant with the preceding audit measure for phosphate alone (of $<1.7 \mathrm{mmol} / \mathrm{L}$ ). This section presents only the audit measure of composite control, however data regarding attainment of each of the three components individually can be found in appendix 1.

There were combined biochemical results to assess mineral bone disease available from $57 \mathrm{HD}$ and $55 \mathrm{PD}$ centres, including 17,684 HD and 2,366 PD patients, from England, Wales and Northern Ireland in 2016. Table 8.7 demonstrates the percentage of patients achieving results within the target range for none, one, two or all three bone mineral parameters, by centre for patients receiving $\mathrm{HD}$ and figure 8.6 shows the variation between centres in the proportion achieving control of all three parameters. Table 8.8 and figure 8.7 show the same data for patients receiving PD.

Overall, 5.0\% of HD and 3.3\% of PD patients across England, Wales and Northern Ireland had none of the three bone mineral parameters controlled within the target ranges described above. Control of one parameter was reported in $24.8 \%$ of $\mathrm{HD}$ and $20.5 \%$ of PD patients;

Table 8.7. Percentage of haemodialysis patients achieving simultaneous control of the three key bone and mineral disorder parameters (adjusted calcium, phosphate and parathyroid hormone) by centre, in 2016

\begin{tabular}{|c|c|c|c|c|c|}
\hline Centre & $N$ & None & One & Two & Three \\
\hline B Heart & 367 & 8.7 & 28.9 & 38.1 & 24.3 \\
\hline Basldn & 132 & 9.8 & 19.7 & 38.6 & 31.8 \\
\hline Bradfd & 225 & 5.8 & 23.1 & 41.8 & 29.3 \\
\hline Bristol & 468 & 5.6 & 29.5 & 42.3 & 22.6 \\
\hline Carlis & 87 & 2.3 & 26.4 & 44.8 & 26.4 \\
\hline Carsh & 641 & 5.6 & 23.7 & 40.7 & 30.0 \\
\hline Chelms & 118 & 2.5 & 19.5 & 50.0 & 28.0 \\
\hline Colchr & 89 & 3.4 & 15.7 & 36.0 & 44.9 \\
\hline Covnt & 341 & 3.8 & 28.7 & 39.9 & 27.6 \\
\hline
\end{tabular}


Table 8.7. Continued

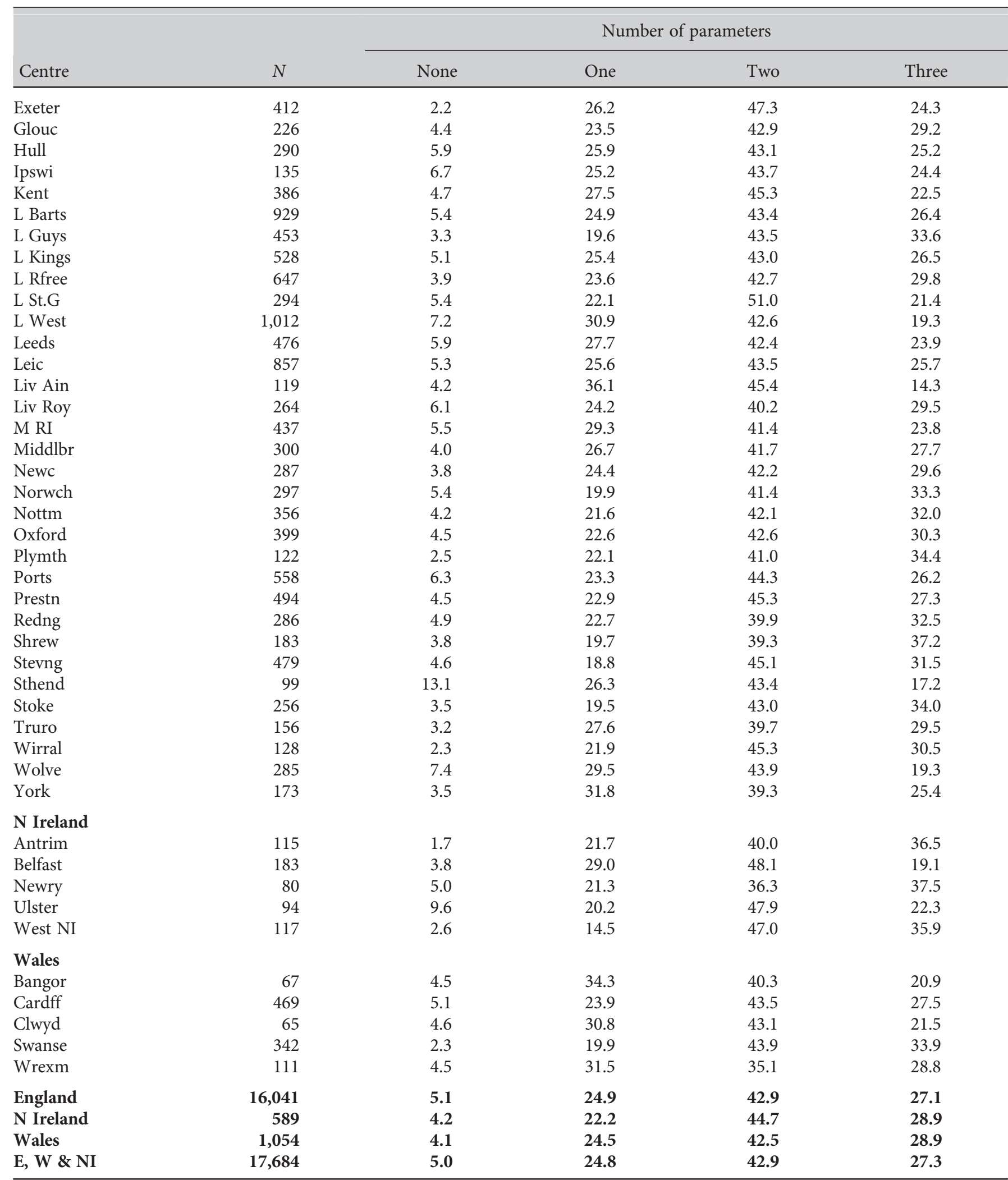

Centres excluded if they did not have at least $50 \%$ completeness for all of the three variables 
Table 8.8. Percentage of peritoneal dialysis patients achieving simultaneous control of the three key bone and mineral disorder parameters (adjusted calcium, phosphate and parathyroid hormone) by centre, in 2016

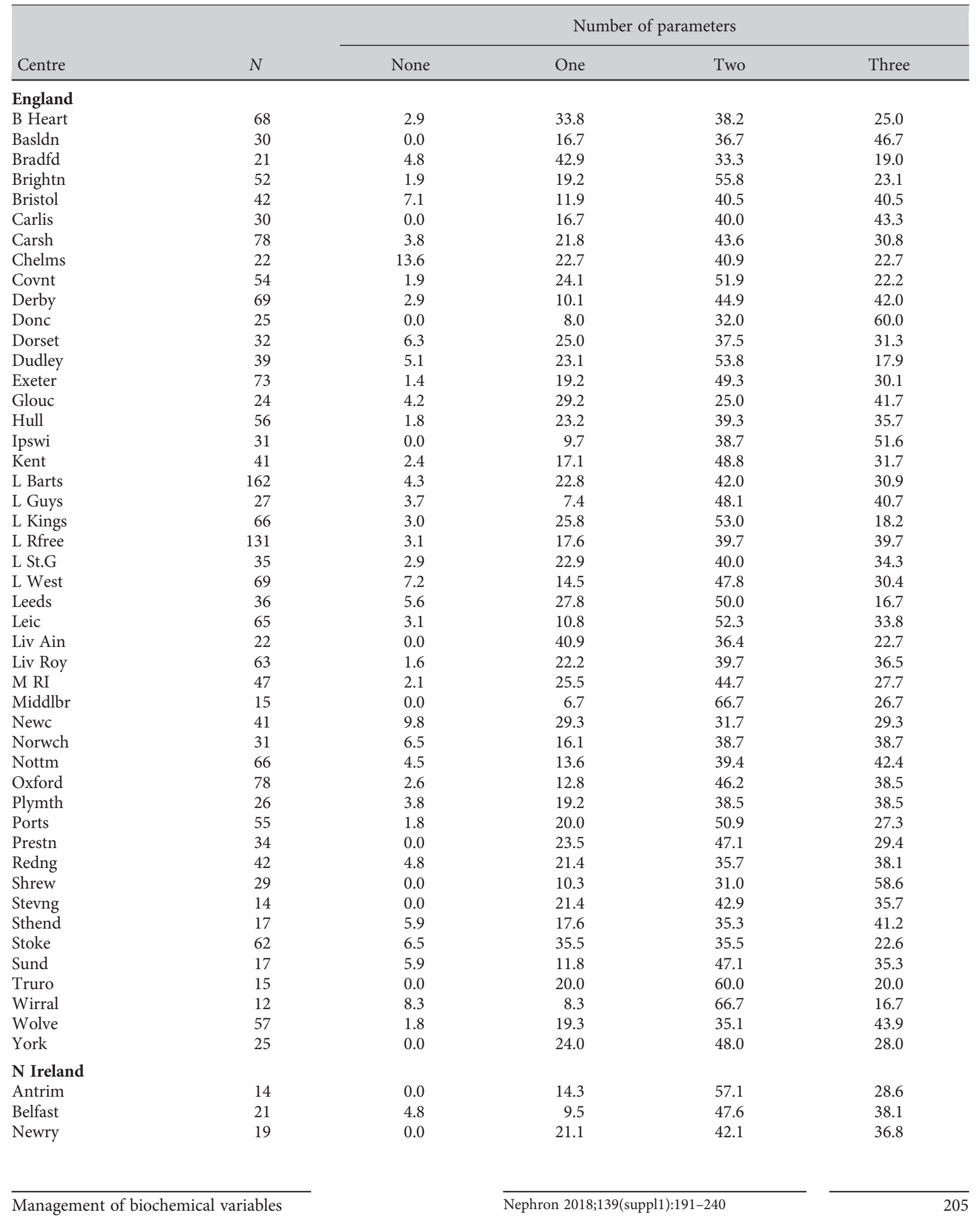


Table 8.8. Continued

\begin{tabular}{|c|c|c|c|c|c|}
\hline \multirow[b]{2}{*}{ Centre } & \multirow[b]{2}{*}{$N$} & \multicolumn{4}{|c|}{ Number of parameters } \\
\hline & & None & One & Two & Three \\
\hline \multicolumn{6}{|l|}{ Wales } \\
\hline Bangor & 15 & 0.0 & 20.0 & 40.0 & 40.0 \\
\hline Cardff & 53 & 3.8 & 28.3 & 34.0 & 34.0 \\
\hline Clwyd & 13 & 0.0 & 30.8 & 38.5 & 30.8 \\
\hline Swanse & 57 & 3.5 & 21.1 & 42.1 & 33.3 \\
\hline Wrexm & 28 & 3.6 & 32.1 & 32.1 & 32.1 \\
\hline England & 2,146 & 3.4 & 20.3 & 43.2 & 33.1 \\
\hline N Ireland & 54 & 1.9 & 14.8 & 48.1 & 35.2 \\
\hline Wales & 166 & 3.0 & 25.9 & 37.3 & 33.7 \\
\hline E, W \& NI & 2,366 & 3.3 & 20.5 & 42.9 & 33.2 \\
\hline
\end{tabular}

Centres excluded if they did not have at least $50 \%$ completeness for all of the three variables

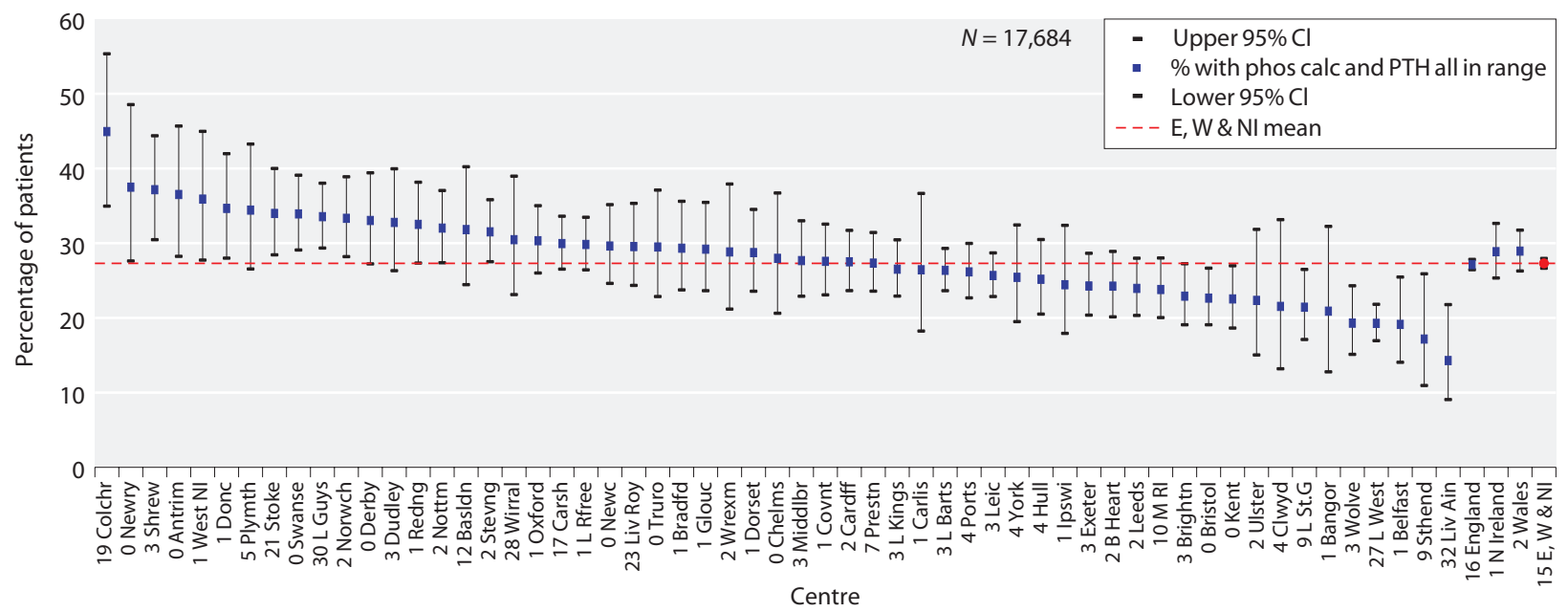

Fig. 8.6. Percentage of HD patients achieving simultaneous control of the three key mineral bone disorders (adjusted calcium, phosphate and parathyroid hormone) in preventing severe hyperparathyroidism, by centre in 2016

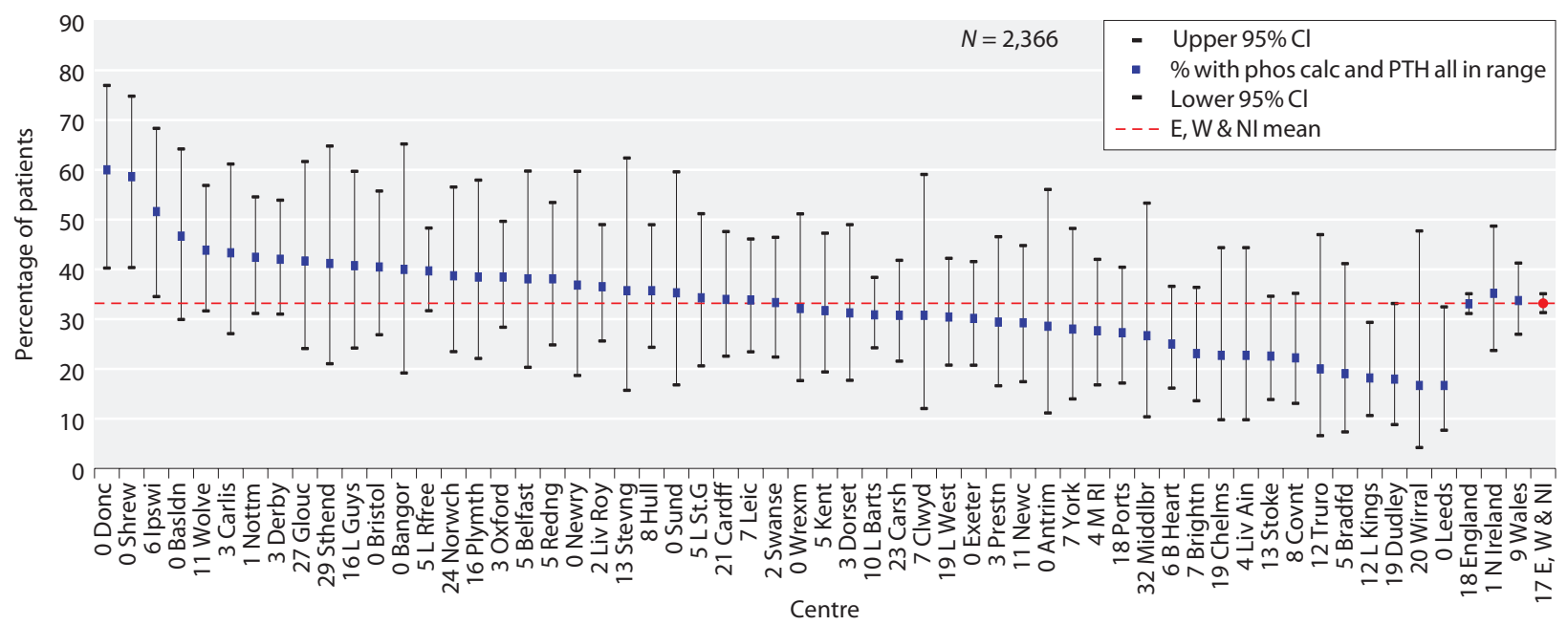

Fig. 8.7. Percentage of PD patients achieving simultaneous control of all three mineral bone disorders (adjusted calcium, phosphate and parathyroid hormone) in preventing severe hyperparathyroidism, by centre in 2016 


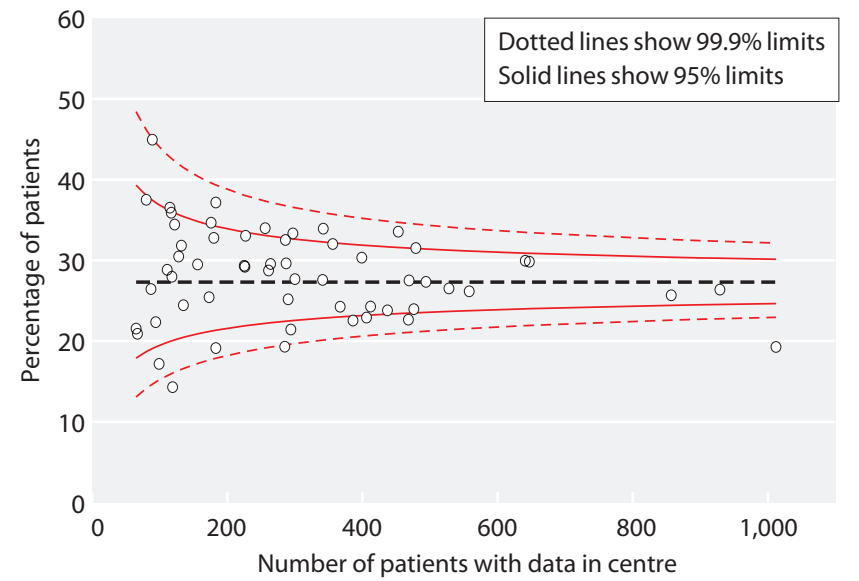

Fig. 8.8. Funnel plot of percentage of HD patients achieving simultaneous control of all three mineral bone disorders (adjusted calcium, phosphate and parathyroid hormone) in preventing severe hyperparathyroidism, by centre in 2016

of two parameters in $42.9 \%$ of both HD and PD patients; of all three parameters in $27.3 \%$ of $\mathrm{HD}$ and $33.2 \%$ of PD patients (tables 8.7, 8.8). In 2015, 27.6\% of HD and 33.1\% of PD patients achieved simultaneous control of all three parameters.

Figures 8.8 and 8.9 are funnel plots showing the percentage with control of the three bone mineral parameters by centre (who contributed data to these analyses). There was some variation in the percentage achieving simultaneous control of the three bone mineral parameters for HD patients, with three centres being below the $99.9 \%$ confidence interval and none above. There was even less variation for PD centres with no centre above or below the $99.9 \%$ confidence interval.

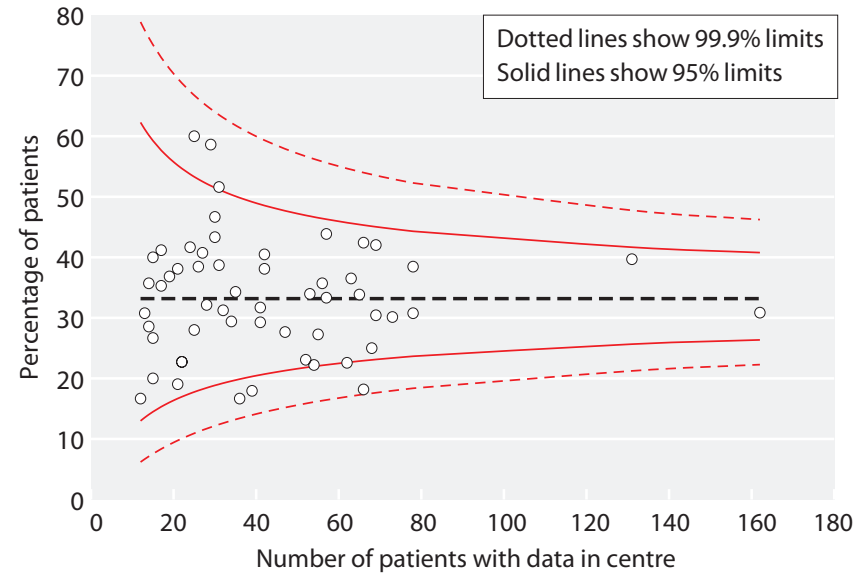

Fig. 8.9. Funnel plot of percentage of PD patients achieving simultaneous control of all three mineral bone disorders (adjusted calcium, phosphate and parathyroid hormone) in preventing severe hyperparathyroidism, by centre in 2016

\section{Bicarbonate}

In 2016 the following RA clinical practice guidelines regarding bicarbonate management were applicable:

Haemodialysis Guideline 6.3 - HD: Pre-dialysis serum bicarbonate concentrations

'We suggest that pre-dialysis serum bicarbonate concentrations, measured with minimum delay after venepuncture, should be between 18 and $24 \mathrm{mmol} / \mathrm{L}^{\prime}$ [3]

Peritoneal Dialysis Guideline 6.2 - PD: Metabolic factors

'We recommend that plasma bicarbonate should be maintained within the normal range' [4]

\section{Haemodialysis}

Table 8.9. Summary statistics for serum bicarbonate in haemodialysis patients by centre in 2016

\begin{tabular}{|c|c|c|c|c|c|c|c|}
\hline Centre & $\begin{array}{c}\% \\
\text { completeness }\end{array}$ & $\begin{array}{c}\text { Patients with } \\
\text { data } N\end{array}$ & Mean & SD & Median & $\begin{array}{l}\text { Lower } \\
\text { quartile }\end{array}$ & $\begin{array}{l}\text { Upper } \\
\text { quartile }\end{array}$ \\
\hline \multicolumn{8}{|l|}{ England } \\
\hline B Heart & 97.9 & 365 & 22.0 & 3.0 & 22 & 20 & 24 \\
\hline B QEH & 98.6 & 925 & 23.2 & 2.5 & 23 & 22 & 25 \\
\hline Basldn & 98.0 & 147 & 23.2 & 2.9 & 23 & 22 & 25 \\
\hline Bradfd & 99.6 & 227 & 24.1 & 2.6 & 24 & 22 & 26 \\
\hline Brightn & 98.3 & 412 & 22.9 & 3.1 & 23 & 21 & 25 \\
\hline Bristol & 100.0 & 470 & 23.9 & 2.4 & 24 & 22 & 25 \\
\hline \multicolumn{8}{|l|}{ Camb* } \\
\hline Carlis & 100.0 & 88 & 21.7 & 2.1 & 22 & 20 & 23 \\
\hline Carsh & 70.8 & 548 & 25.2 & 2.5 & 25 & 24 & 27 \\
\hline Chelms & 100.0 & 118 & 22.4 & 2.2 & 22 & 21 & 24 \\
\hline
\end{tabular}


Table 8.9. Continued

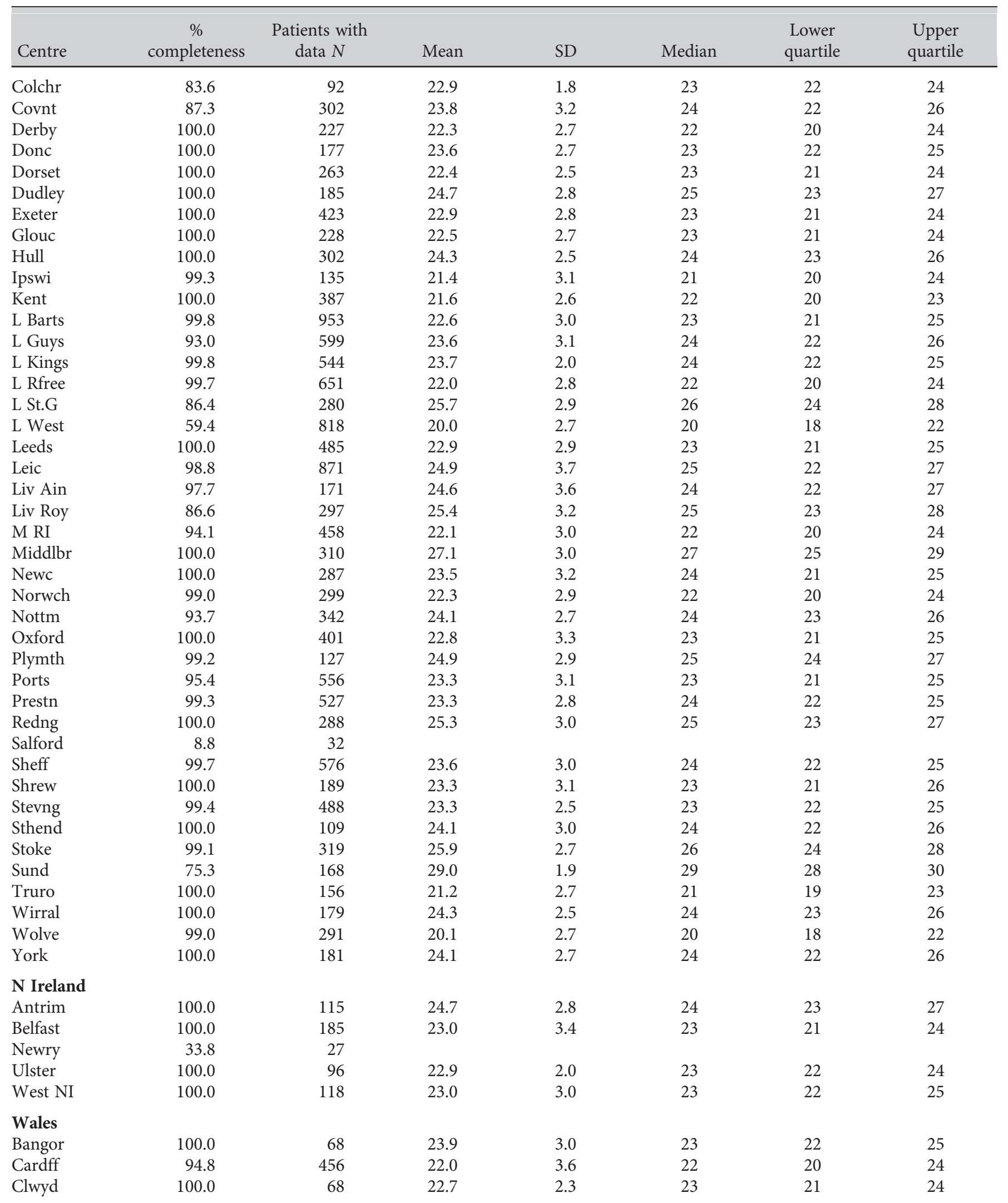


Table 8.9. Continued

\begin{tabular}{|c|c|c|c|c|c|c|c|}
\hline Centre & $\begin{array}{c}\% \\
\text { completeness }\end{array}$ & $\begin{array}{c}\text { Patients with } \\
\text { data } N\end{array}$ & Mean & SD & Median & $\begin{array}{l}\text { Lower } \\
\text { quartile }\end{array}$ & $\begin{array}{l}\text { Upper } \\
\text { quartile }\end{array}$ \\
\hline Swanse & 100.0 & 343 & 23.6 & 2.9 & 24 & 22 & 26 \\
\hline England & 92.2 & 17,973 & 23.3 & 3.2 & 23 & 21 & 25 \\
\hline N Ireland & 91.1 & 541 & 23.3 & 3.0 & 23 & 22 & 25 \\
\hline
\end{tabular}

Blank cells: centres excluded from analysis due to low patient numbers or poor data completeness

* Cambridge renal centre was unable to submit bicarbonate data for 2016

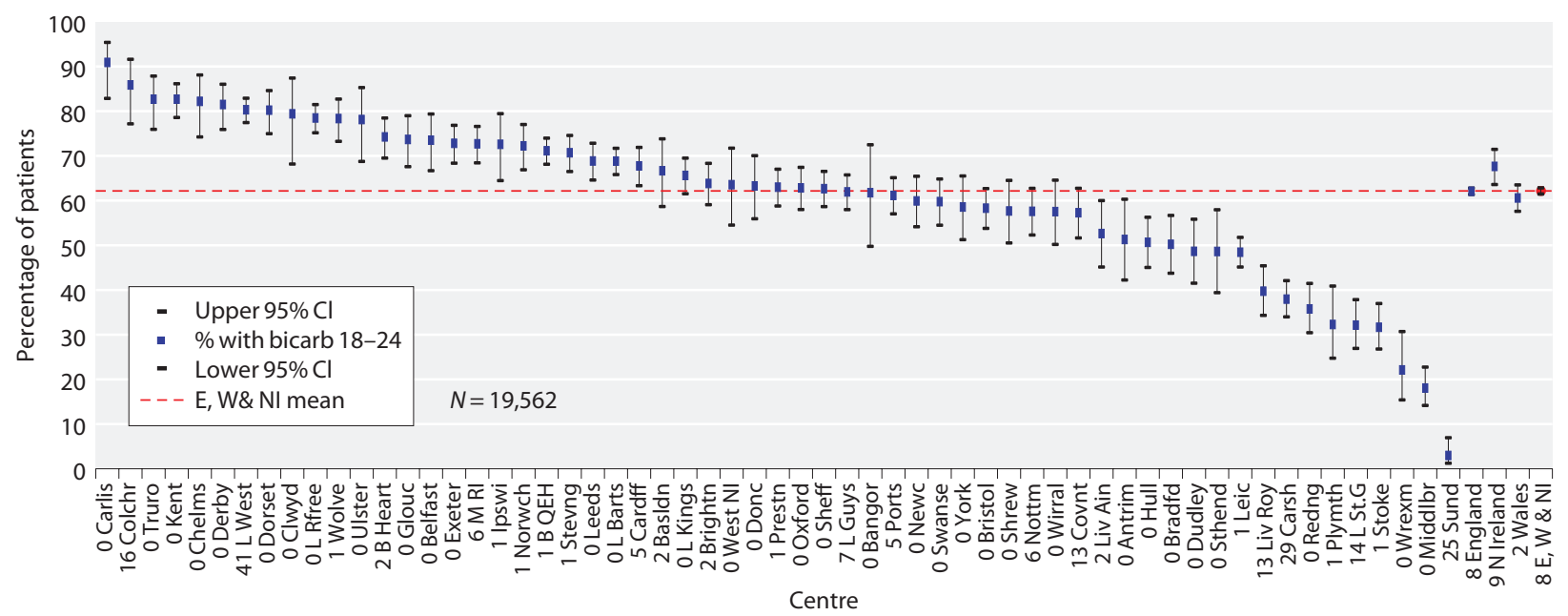

Fig. 8.10. Percentage of haemodialysis patients with serum bicarbonate within range (18-24 mmol/L) by centre in 2016

A total of 19,562 HD and 2,538 PD patients' data were available for serum bicarbonate analysis from England, Wales and Northern Ireland in 2016. Data were 92.5\% complete for HD patients and $88.3 \%$ complete for PD patients (tables 8.9, 8.11). Data completeness for serum bicarbonate levels in HD and PD patients has not changed significantly over a decade. The proportion of HD patients with serum bicarbonate within the audit measure range was $62.2 \%$ in 2016 (95\% CI 61.5-62.8\%) (table 8.10); the mean bicarbonate in HD patients was $23.3 \mathrm{mmol} / \mathrm{L}$ (table 8.9). The proportion with serum bicarbonate within the audit standard in PD patients was $80.7 \%$ (CI 79.2-82.2\%) (table 8.12). The mean bicarbonate level in PD patients was $25.1 \mathrm{mmol} / \mathrm{L}$ (table 8.11).

As in previous reports, inter-centre variation was observed in attainment of the audit standard (tables 8.10, 8.12 , figures $8.10-8.13$ ). The funnel plot of serum bicarbonate values in 2016 for $\mathrm{HD}$ patients (figure 8.11) showed a large dispersal of attainment, 21 centres being

Management of biochemical variables above the $99.9 \%$ limit and 13 below the $99.9 \%$ limit. In contrast, the funnel plot for PD patients (figure 8.13) showed few outliers. Sample processing, case-mix, differences in dialysis, residual renal function and oral

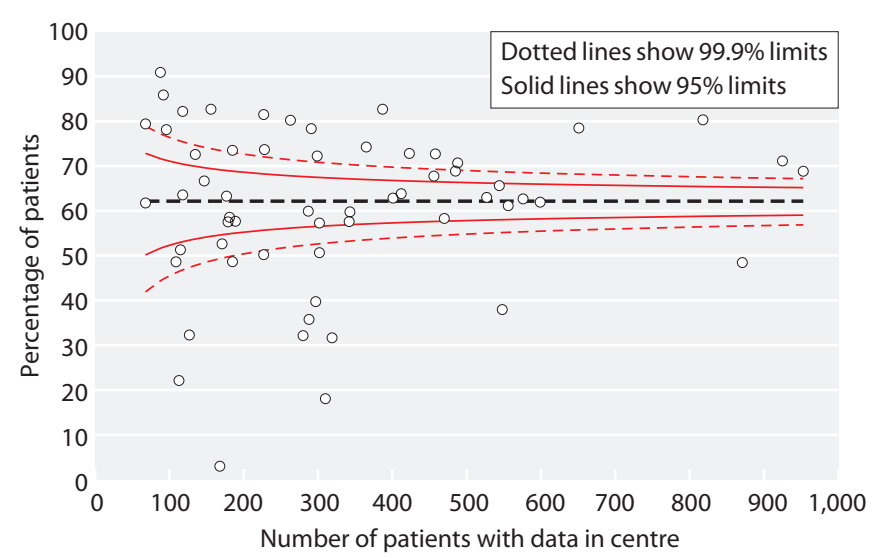

Fig. 8.11. Funnel plot for percentage of haemodialysis patients within range for bicarbonate $(18-24 \mathrm{mmol} / \mathrm{L})$ by centre in 2016 
Table 8.10. Percentage of haemodialysis patients within, below and above the range for bicarbonate (18-24 mmol/L) by centre in 2016

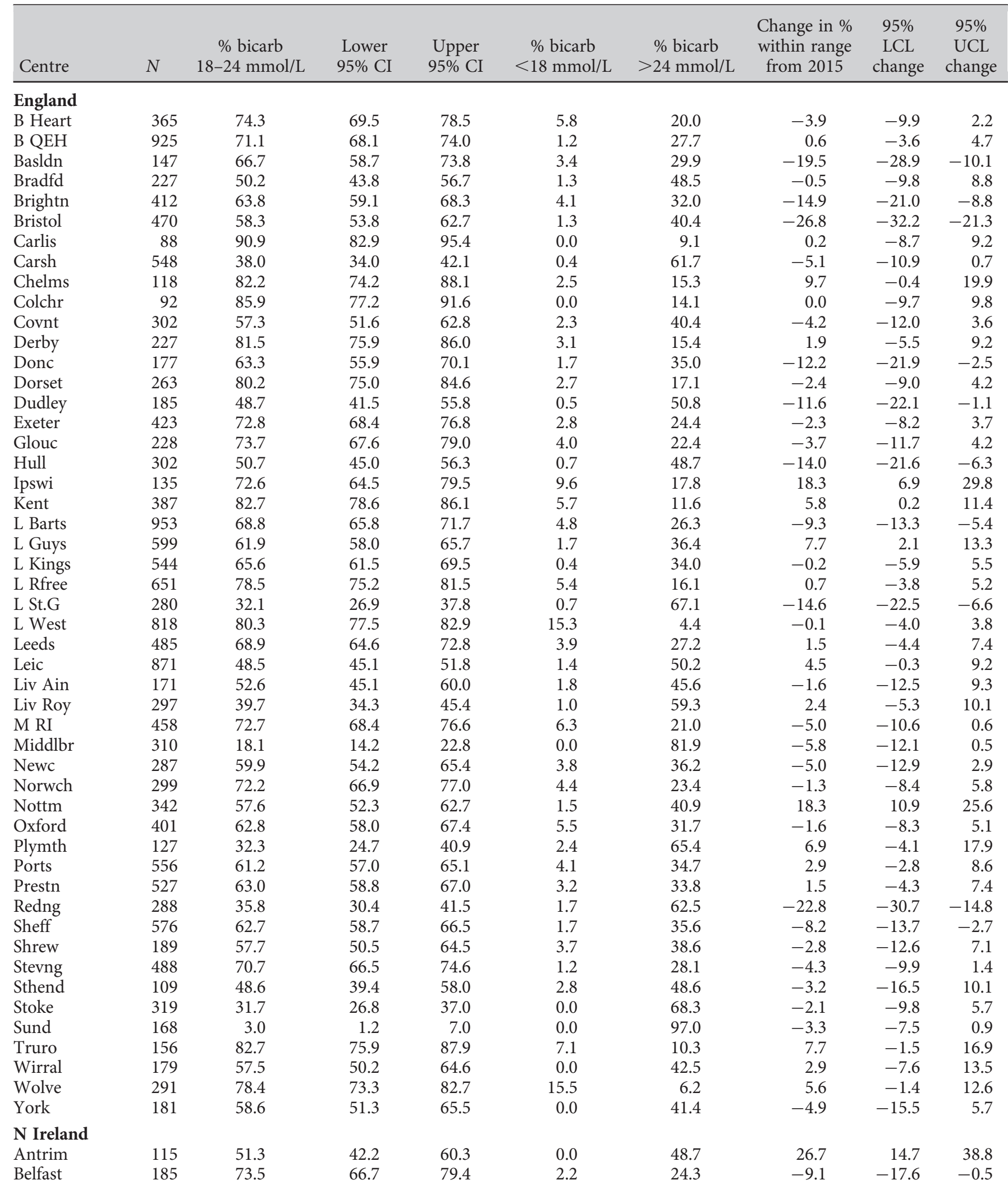


Table 8.10. Continued

\begin{tabular}{|c|c|c|c|c|c|c|c|c|c|}
\hline Centre & $N$ & $\begin{array}{c}\% \text { bicarb } \\
18-24 \mathrm{mmol} / \mathrm{L}\end{array}$ & $\begin{array}{l}\text { Lower } \\
95 \% \text { CI }\end{array}$ & $\begin{array}{l}\text { Upper } \\
95 \% \text { CI }\end{array}$ & $\begin{array}{c}\% \text { bicarb } \\
<18 \mathrm{mmol} / \mathrm{L}\end{array}$ & $\begin{array}{c}\% \text { bicarb } \\
>24 \mathrm{mmol} / \mathrm{L}\end{array}$ & $\begin{array}{l}\text { Change in \% } \\
\text { within range } \\
\text { from } 2015\end{array}$ & $\begin{array}{l}95 \% \\
\text { LCL } \\
\text { change }\end{array}$ & $\begin{array}{c}95 \% \\
\text { UCL } \\
\text { change }\end{array}$ \\
\hline Ulster & 96 & 78.1 & 68.8 & 85.3 & 1.0 & 20.8 & -6.3 & -17.3 & 4.8 \\
\hline West NI & 118 & 63.6 & 54.5 & 71.7 & 3.4 & 33.1 & -24.9 & -35.4 & -14.5 \\
\hline \multicolumn{10}{|l|}{ Wales } \\
\hline Bangor & 68 & 61.8 & 49.8 & 72.5 & 1.5 & 36.8 & -1.1 & -16.8 & 14.7 \\
\hline Cardff & 456 & 67.8 & 63.3 & 71.9 & 8.3 & 23.9 & 7.1 & 0.8 & 13.4 \\
\hline Clwyd & 68 & 79.4 & 68.2 & 87.4 & 0.0 & 20.6 & 12.3 & -2.0 & 26.6 \\
\hline Swanse & 343 & 59.8 & 54.5 & 64.8 & 2.0 & 38.2 & -4.3 & -11.5 & 3.0 \\
\hline Wrexm & 113 & 22.1 & 15.4 & 30.7 & 0.9 & 77.0 & -2.1 & -13.5 & 9.3 \\
\hline England & 17,973 & 62.1 & 61.4 & 62.8 & 3.4 & 34.5 & -2.4 & -3.4 & -1.4 \\
\hline N Ireland & 541 & 67.7 & 63.6 & 71.5 & 1.9 & 30.5 & -3.0 & -8.4 & 2.4 \\
\hline Wales & 1,048 & 60.6 & 57.6 & 63.5 & 4.5 & 34.9 & 1.7 & -2.6 & 5.9 \\
\hline $\mathrm{E}, \mathrm{W} \& \mathrm{NI}$ & 19,562 & 62.2 & 61.5 & 62.8 & 3.5 & 34.4 & -2.2 & -3.2 & -1.3 \\
\hline
\end{tabular}

Centres missing from the table were excluded from analysis due to low patient numbers or poor data completeness

\section{Peritoneal dialysis}

Table 8.11. Summary statistics for serum bicarbonate in peritoneal dialysis patients by centre in 2016

\begin{tabular}{|c|c|c|c|c|c|c|c|}
\hline Centre & $\begin{array}{c}\% \\
\text { completeness }\end{array}$ & $\begin{array}{c}\text { Patients with } \\
\text { data } N\end{array}$ & Mean & SD & Median & $\begin{array}{l}\text { Lower } \\
\text { quartile }\end{array}$ & $\begin{array}{l}\text { Upper } \\
\text { quartile }\end{array}$ \\
\hline \multicolumn{8}{|l|}{ England } \\
\hline B Heart & 100.0 & 72 & 22.5 & 2.7 & 23 & 21 & 25 \\
\hline B QEH & 91.2 & 114 & 24.4 & 3.2 & 24 & 22 & 27 \\
\hline Basldn & 100.0 & 30 & 26.5 & 3.6 & 26 & 24 & 30 \\
\hline Bradfd & 100.0 & 22 & 27.9 & 3.1 & 28 & 26 & 30 \\
\hline Brightn & 98.2 & 55 & 27.0 & 2.9 & 27 & 25 & 29 \\
\hline Bristol & 100.0 & 42 & 23.2 & 2.4 & 23 & 22 & 25 \\
\hline \multicolumn{8}{|l|}{$\mathrm{Camb}^{\mathrm{a}}$} \\
\hline Carlis & 100.0 & 31 & 25.0 & 3.1 & 25 & 23 & 27 \\
\hline Carsh & 0.0 & - & & & & & \\
\hline Chelms & 85.2 & 23 & 24.5 & 3.5 & 24 & 22 & 27 \\
\hline \multicolumn{8}{|l|}{ Colchr ${ }^{\mathrm{b}}$} \\
\hline Covnt & 94.9 & 56 & 25.7 & 3.4 & 25 & 23 & 28 \\
\hline Derby & 100.0 & 71 & 23.9 & 3.0 & 24 & 23 & 26 \\
\hline Donc & 100.0 & 25 & 24.5 & 2.5 & 25 & 23 & 26 \\
\hline Dorset & 100.0 & 33 & 23.4 & 3.5 & 23 & 21 & 26 \\
\hline Dudley & 100.0 & 48 & 25.6 & 3.8 & 25 & 23 & 29 \\
\hline Exeter & 100.0 & 73 & 24.0 & 2.9 & 24 & 22 & 26 \\
\hline Glouc & 97.0 & 32 & 24.0 & 3.7 & 23 & 22 & 27 \\
\hline Hull & 100.0 & 61 & 25.9 & 2.8 & 26 & 24 & 28 \\
\hline Ipswi & 97.0 & 32 & 25.7 & 3.6 & 26 & 24 & 28 \\
\hline Kent & 95.4 & 41 & 24.9 & 3.5 & 25 & 23 & 27 \\
\hline L Barts & 97.8 & 175 & 23.5 & 3.6 & 24 & 21 & 26 \\
\hline L Guys & 100.0 & 32 & 25.5 & 2.8 & 26 & 24 & 27 \\
\hline L Kings & 100.0 & 75 & 27.4 & 2.3 & 28 & 26 & 29 \\
\hline L Rfree & 85.5 & 118 & 25.2 & 3.6 & 25 & 23 & 28 \\
\hline L St.G & 97.3 & 36 & 24.6 & 2.5 & 25 & 23 & 27 \\
\hline L West & 87.1 & 74 & 23.1 & 2.9 & 23 & 21 & 25 \\
\hline Leeds & 100.0 & 36 & 27.2 & 3.7 & 28 & 26 & 30 \\
\hline Leic & 95.7 & 67 & 25.9 & 3.4 & 26 & 24 & 28 \\
\hline Liv Ain & 100.0 & 23 & 26.2 & 2.6 & 26 & 25 & 28 \\
\hline
\end{tabular}


Table 8.11. Continued

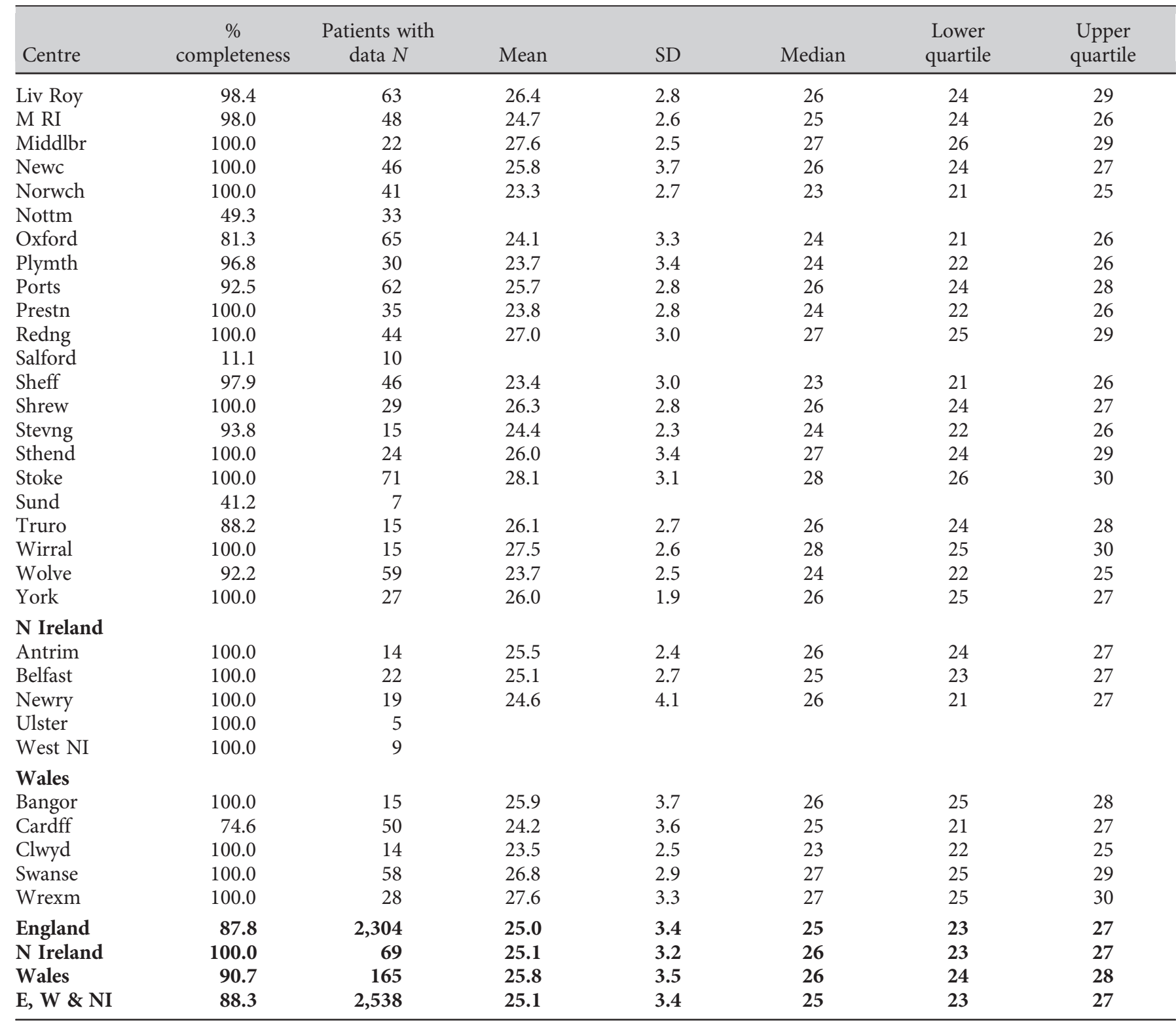

Blank cells: centres excluded from analysis due to low patient numbers or poor data completeness

${ }^{a}$ Cambridge renal centre was unable to submit bicarbonate data for 2016

${ }^{\mathrm{b} C o l c h e s t e r}$ - no PD patients

bicarbonate prescriptions may all contribute to the variation observed.

Serial trends in serum bicarbonate measures between 2006 and 2016 by dialysis modality are presented in figure 8.14. Achievement of bicarbonate audit measures has not changed significantly over the past decade for either modality. There has been a consistent difference between the modalities in the percentage with raised bicarbonate measures.

\section{Potassium}

In 2016 the following RA clinical practice guideline regarding potassium management in haemodialysis was applicable:

Haemodialysis Guideline 6.4 - HD: Pre-dialysis serum potassium concentrations

'We suggest that pre-dialysis serum potassium should be between 4.0 and $6.0 \mathrm{mmol} / \mathrm{L}$ in HD patients.' [3] 
Table 8.12. Percentage of peritoneal dialysis patients within, below and above the range for bicarbonate $(22-30 \mathrm{mmol} / \mathrm{L})$ by centre in 2016

\begin{tabular}{|c|c|c|c|c|c|c|c|c|c|}
\hline Centre & $N$ & $\begin{array}{c}\% \text { bicarb } \\
22-30 \mathrm{mmol} / \mathrm{L}\end{array}$ & $\begin{array}{l}\text { Lower } \\
95 \% \text { CI }\end{array}$ & $\begin{array}{c}\text { Upper } \\
95 \% \text { CI }\end{array}$ & $\begin{array}{c}\% \text { bicarb } \\
<22 \mathrm{mmol} / \mathrm{L}\end{array}$ & $\begin{array}{c}\% \text { bicarb } \\
>30 \mathrm{mmol} / \mathrm{L}\end{array}$ & $\begin{array}{c}\text { Change in } \% \\
\text { within range } \\
\text { from } 2015\end{array}$ & $\begin{array}{c}95 \% \\
\text { LCL } \\
\text { change }\end{array}$ & $\begin{array}{c}95 \% \\
\text { UCL } \\
\text { change }\end{array}$ \\
\hline \multicolumn{10}{|l|}{ England } \\
\hline B Heart & 72 & 63.9 & 52.2 & 74.1 & 36.1 & 0.0 & 8.9 & -10.1 & 27.9 \\
\hline B QEH & 114 & 85.1 & 77.3 & 90.5 & 14.0 & 0.9 & 3.8 & -5.9 & 13.6 \\
\hline Basldn & 30 & 70.0 & 51.7 & 83.6 & 10.0 & 20.0 & -15.2 & -36.4 & 6.0 \\
\hline Bradfd & 22 & 81.8 & 60.4 & 93.0 & 4.6 & 13.6 & -10.5 & -32.2 & 11.2 \\
\hline Brightn & 55 & 85.5 & 73.5 & 92.6 & 3.6 & 10.9 & 3.8 & -9.7 & 17.3 \\
\hline Bristol & 42 & 78.6 & 63.7 & 88.5 & 21.4 & 0.0 & 33.9 & 15.0 & 52.8 \\
\hline Carlis & 31 & 83.9 & 66.6 & 93.1 & 9.7 & 6.5 & 3.9 & -15.4 & 23.2 \\
\hline Chelms & 23 & 73.9 & 52.8 & 87.8 & 17.4 & 8.7 & -7.9 & -32.0 & 16.2 \\
\hline Covnt & 56 & 80.4 & 67.9 & 88.8 & 10.7 & 8.9 & -2.7 & -16.6 & 11.1 \\
\hline Derby & 71 & 78.9 & 67.9 & 86.8 & 21.1 & 0.0 & -1.9 & -15.1 & 11.2 \\
\hline Donc & 25 & 88.0 & 68.7 & 96.1 & 12.0 & 0.0 & 26.9 & 1.0 & 52.8 \\
\hline Dorset & 33 & 69.7 & 52.3 & 82.9 & 30.3 & 0.0 & 1.1 & -20.8 & 23.1 \\
\hline Dudley & 48 & 72.9 & 58.8 & 83.6 & 16.7 & 10.4 & -13.6 & -29.2 & 2.0 \\
\hline Exeter & 73 & 84.9 & 74.8 & 91.5 & 15.1 & 0.0 & 7.5 & -5.3 & 20.2 \\
\hline Glouc & 32 & 71.9 & 54.2 & 84.7 & 25.0 & 3.1 & -10.3 & -31.3 & 10.8 \\
\hline Hull & 61 & 90.2 & 79.8 & 95.5 & 4.9 & 4.9 & 10.5 & -1.9 & 22.8 \\
\hline Ipswi & 32 & 87.5 & 71.1 & 95.2 & 9.4 & 3.1 & -5.1 & -20.2 & 10.0 \\
\hline Kent & 41 & 80.5 & 65.6 & 89.9 & 14.6 & 4.9 & -4.7 & -20.1 & 10.7 \\
\hline L Barts & 175 & 72.0 & 64.9 & 78.2 & 26.9 & 1.1 & -9.6 & -18.3 & -0.8 \\
\hline L Guys & 32 & 87.5 & 71.1 & 95.2 & 6.3 & 6.3 & 4.7 & -13.2 & 22.6 \\
\hline L Kings & 75 & 89.3 & 80.1 & 94.6 & 2.7 & 8.0 & -3.1 & -12.2 & 6.0 \\
\hline L Rfree & 118 & 82.2 & 74.2 & 88.1 & 15.3 & 2.5 & -1.3 & -11.1 & 8.5 \\
\hline L St.G & 36 & 86.1 & 70.7 & 94.1 & 13.9 & 0.0 & -9.2 & -22.2 & 3.7 \\
\hline L West & 74 & 70.3 & 59.0 & 79.6 & 28.4 & 1.4 & 5.1 & -12.2 & 22.3 \\
\hline Leeds & 36 & 80.6 & 64.5 & 90.4 & 11.1 & 8.3 & 10.6 & -7.6 & 28.7 \\
\hline Leic & 67 & 82.1 & 71.1 & 89.5 & 9.0 & 9.0 & 7.4 & -5.4 & 20.2 \\
\hline Liv Ain & 23 & 87.0 & 66.5 & 95.7 & 4.4 & 8.7 & -5.6 & -22.6 & 11.3 \\
\hline Liv Roy & 63 & 90.5 & 80.4 & 95.7 & 3.2 & 6.4 & 2.0 & -8.8 & 12.8 \\
\hline M RI & 48 & 85.4 & 72.4 & 92.9 & 12.5 & 2.1 & 9.6 & -5.3 & 24.4 \\
\hline Middlbr & 22 & 90.9 & 70.0 & 97.7 & 0.0 & 9.1 & 33.8 & 5.2 & 62.3 \\
\hline Newc & 46 & 87.0 & 73.9 & 94.0 & 10.9 & 2.2 & 0.1 & -14.4 & 14.6 \\
\hline Norwch & 41 & 65.9 & 50.3 & 78.6 & 31.7 & 2.4 & -0.8 & -23.8 & 22.1 \\
\hline Oxford & 65 & 69.2 & 57.1 & 79.2 & 27.7 & 3.1 & -3.6 & -18.9 & 11.7 \\
\hline Plymth & 30 & 80.0 & 62.1 & 90.7 & 20.0 & 0.0 & -0.8 & -21.6 & 20.1 \\
\hline Ports & 62 & 87.1 & 76.3 & 93.4 & 9.7 & 3.2 & 3.8 & -9.2 & 16.7 \\
\hline Prestn & 35 & 77.1 & 60.5 & 88.1 & 22.9 & 0.0 & -8.6 & -25.6 & 8.4 \\
\hline Redng & 44 & 84.1 & 70.2 & 92.2 & 2.3 & 13.6 & -4.1 & -17.6 & 9.5 \\
\hline Sheff & 46 & 71.7 & 57.2 & 82.8 & 28.3 & 0.0 & 7.4 & -10.6 & 25.5 \\
\hline Shrew & 29 & 96.6 & 79.2 & 99.5 & 0.0 & 3.5 & 7.7 & -5.9 & 21.2 \\
\hline Stevng & 15 & 86.7 & 59.5 & 96.6 & 13.3 & 0.0 & 11.7 & -18.3 & 41.6 \\
\hline Sthend & 24 & 83.3 & 63.1 & 93.6 & 12.5 & 4.2 & -16.7 & -31.6 & -1.8 \\
\hline Stoke & 71 & 77.5 & 66.3 & 85.7 & 1.4 & 21.1 & -10.8 & -23.2 & 1.6 \\
\hline Truro & 15 & 93.3 & 64.8 & 99.1 & 0.0 & 6.7 & 5.1 & -14.8 & 24.9 \\
\hline Wirral & 15 & 86.7 & 59.5 & 96.6 & 0.0 & 13.3 & -1.6 & -24.6 & 21.5 \\
\hline Wolve & 59 & 88.1 & 77.1 & 94.2 & 11.9 & 0.0 & 22.5 & 8.4 & 36.5 \\
\hline York & 27 & 96.3 & 77.9 & 99.5 & 3.7 & 0.0 & 15.4 & -2.9 & 33.6 \\
\hline \multicolumn{10}{|l|}{ N Ireland } \\
\hline Antrim & 14 & 92.9 & 63.0 & 99.0 & 7.1 & 0.0 & 4.6 & -15.8 & 25.0 \\
\hline Belfast & 22 & 90.9 & 70.0 & 97.7 & 9.1 & 0.0 & 1.4 & -16.9 & 19.7 \\
\hline Newry & 19 & 68.4 & 45.2 & 85.1 & 26.3 & 5.3 & -14.9 & -42.0 & 12.2 \\
\hline
\end{tabular}


Table 8.12. Continued

\begin{tabular}{|c|c|c|c|c|c|c|c|c|c|}
\hline Centre & $N$ & $\begin{array}{c}\% \text { bicarb } \\
22-30 \mathrm{mmol} / \mathrm{L}\end{array}$ & $\begin{array}{l}\text { Lower } \\
95 \% \text { CI }\end{array}$ & $\begin{array}{c}\text { Upper } \\
95 \% \text { CI }\end{array}$ & $\begin{array}{c}\% \text { bicarb } \\
<22 \mathrm{mmol} / \mathrm{L}\end{array}$ & $\begin{array}{c}\% \text { bicarb } \\
>30 \mathrm{mmol} / \mathrm{L}\end{array}$ & $\begin{array}{c}\text { Change in \% } \\
\text { within range } \\
\text { from } 2015\end{array}$ & $\begin{array}{c}95 \% \\
\text { LCL } \\
\text { change }\end{array}$ & $\begin{array}{c}95 \% \\
\text { UCL } \\
\text { change }\end{array}$ \\
\hline \multicolumn{10}{|l|}{ Wales } \\
\hline Bangor & 15 & 86.7 & 59.5 & 96.6 & 6.7 & 6.7 & -5.6 & -28.1 & 16.8 \\
\hline Cardff & 50 & 70.0 & 56.0 & 81.0 & 28.0 & 2.0 & -21.2 & -35.6 & -6.8 \\
\hline Clwyd & 14 & 78.6 & 50.6 & 92.9 & 21.4 & 0.0 & 1.6 & -29.8 & 33.1 \\
\hline Swanse & 58 & 84.5 & 72.8 & 91.7 & 1.7 & 13.8 & -6.3 & -18.4 & 5.8 \\
\hline Wrexm & 28 & 82.1 & 63.6 & 92.4 & 0.0 & 17.9 & 0.3 & -19.0 & 19.7 \\
\hline England & 2,304 & 80.8 & 79.1 & 82.3 & 14.8 & 4.4 & 1.1 & -1.2 & 3.4 \\
\hline N Ireland & 69 & 82.6 & 71.8 & 89.9 & 14.5 & 2.9 & -4.3 & -16.3 & 7.6 \\
\hline Wales & 165 & 79.4 & 72.5 & 84.9 & 11.5 & 9.1 & -9.0 & -16.7 & -1.3 \\
\hline $\mathrm{E}, \mathrm{W} \& \mathrm{NI}$ & 2,538 & 80.7 & 79.2 & 82.2 & 14.6 & 4.7 & 0.3 & -1.9 & 2.5 \\
\hline
\end{tabular}

Centres missing from the table were excluded from analysis due to low patient numbers or poor data completeness

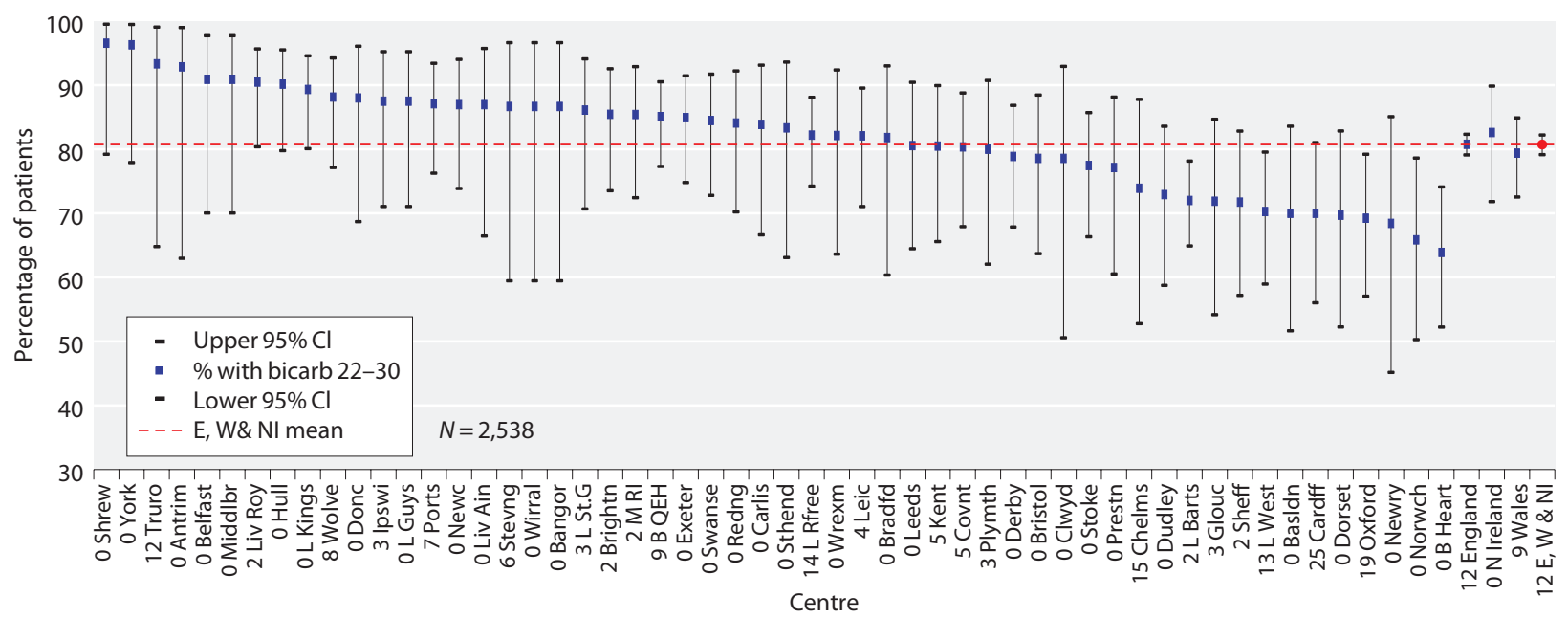

Fig. 8.12. Percentage of peritoneal dialysis patients with serum bicarbonate within range (22-30 mmol/L) by centre in 2016

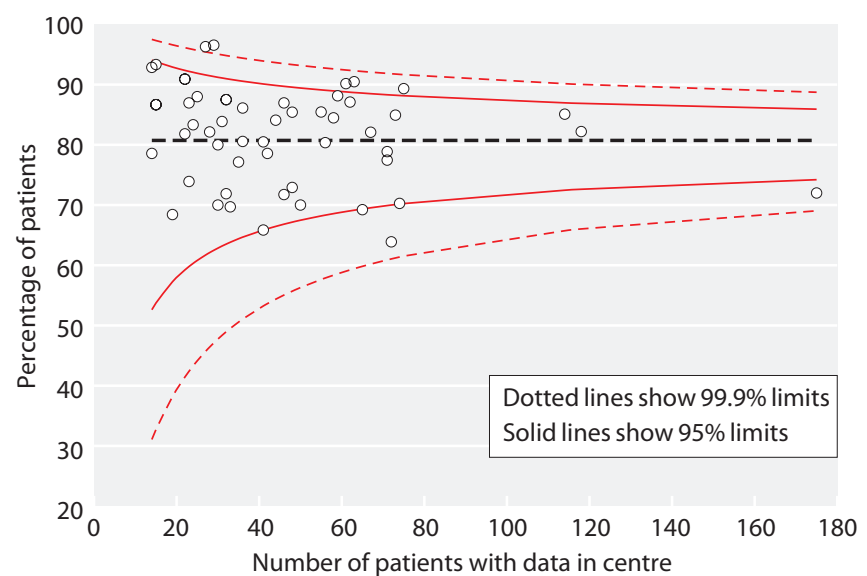

Fig. 8.13. Funnel plot for percentage of peritoneal dialysis patients within range for bicarbonate $(22-30 \mathrm{mmol} / \mathrm{L})$ by centre in 2016
The PD guideline contains no recommendation with regard to serum potassium.

A total of 10,568 HD patients' data were available for serum potassium analysis from 27 centres in England, all five centres in Northern Ireland but no centres in Wales in 2016. In total, data were $50.0 \%$ complete for $\mathrm{HD}$ patients (table 8.13). However, when considering only centres that submitted at least some data for serum potassium, centre completeness was $98 \%$ or higher apart from Stoke. The proportion of HD patients with serum potassium within the audit measure range was $84.1 \%$ in 2016 (95\% CI 83.4-84.8\%) (table 8.14); the mean serum potassium in HD patients was $4.9 \mathrm{mmol} / \mathrm{L}$ (table 8.13).

Some inter-centre variation was observed in attainment of the audit standard (table 8.14, figures 8.15, 8.16). One centre was above and one below the $99.9 \%$ 


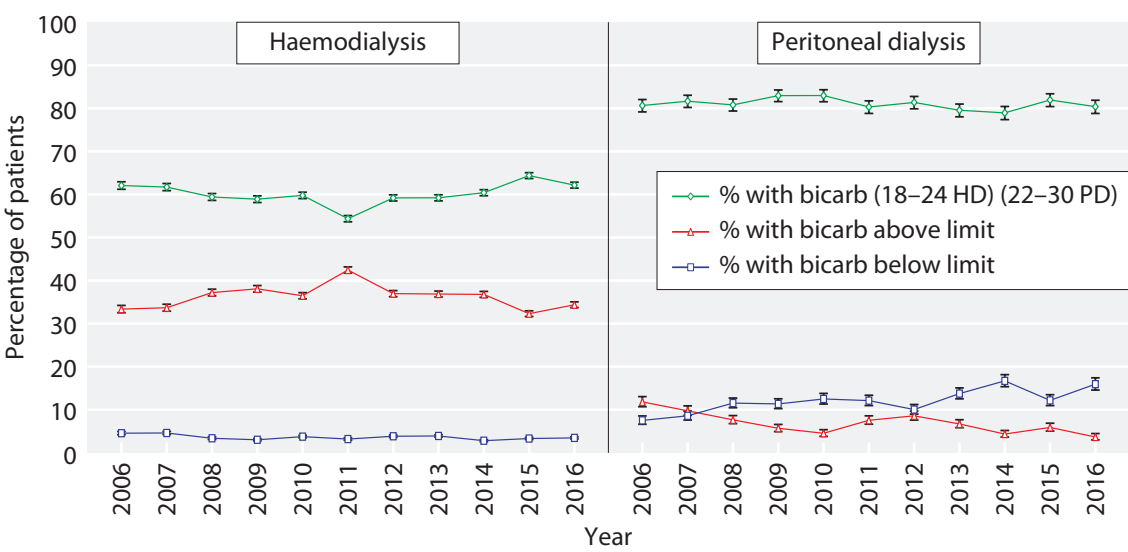

Fig. 8.14. Longitudinal change in percentage of patients within the range for bicarbonate by dialysis modality 2006-2016

\section{Haemodialysis}

Table 8.13. Summary statistics for serum potassium in haemodialysis patients by centre in 2016

\begin{tabular}{|c|c|c|c|c|c|c|c|}
\hline Centre & $\begin{array}{c}\% \\
\text { completeness }\end{array}$ & $\begin{array}{c}\text { Patients with data } \\
N\end{array}$ & Mean & $\mathrm{SD}$ & Median & $\begin{array}{c}\text { Lower } \\
\text { quartile }\end{array}$ & $\begin{array}{l}\text { Upper } \\
\text { quartile }\end{array}$ \\
\hline \multicolumn{8}{|l|}{ England } \\
\hline B Heart & 100.0 & 373 & 4.9 & 0.8 & 4.8 & 4.4 & 5.3 \\
\hline B QEH & 99.8 & 936 & 4.9 & 0.8 & 4.8 & 4.4 & 5.4 \\
\hline Basldn & 98.0 & 147 & 4.7 & 0.7 & 4.7 & 4.3 & 5.2 \\
\hline Bradfd & 99.6 & 227 & 4.7 & 0.8 & 4.6 & 4.1 & 5.1 \\
\hline Brightn & 0.0 & 0 & & & & & \\
\hline Bristol & 100.0 & 470 & 4.7 & 0.7 & 4.6 & 4.2 & 5.1 \\
\hline \multicolumn{8}{|l|}{$\mathrm{Camb}^{\mathrm{a}}$} \\
\hline Carlis $^{\text {b }}$ & 0.0 & 0 & & & & & \\
\hline Carsh & 0.0 & 0 & & & & & \\
\hline Chelms & 100.0 & 118 & 5.1 & 0.6 & 5.1 & 4.7 & 5.4 \\
\hline Colchr ${ }^{\mathrm{b}}$ & 0.0 & 0 & & & & & \\
\hline Covnt $^{\mathrm{c}}$ & 0.0 & 0 & & & & & \\
\hline Derby & 0.0 & 0 & & & & & \\
\hline Donc & 100.0 & 177 & 4.9 & 0.7 & 4.8 & 4.4 & 5.3 \\
\hline Dorset & 100.0 & 263 & 4.9 & 0.7 & 4.9 & 4.4 & 5.3 \\
\hline Dudley & 100.0 & 185 & 4.9 & 0.8 & 4.9 & 4.4 & 5.4 \\
\hline Exeter & 100.0 & 423 & 4.6 & 0.8 & 4.6 & 4.1 & 5.1 \\
\hline Glouc & 0.0 & 0 & & & & & \\
\hline Hull & 100.0 & 302 & 4.7 & 0.7 & 4.7 & 4.3 & 5.2 \\
\hline Ipswi & 0.0 & 0 & & & & & \\
\hline Kent & 100.0 & 387 & 4.7 & 0.9 & 4.8 & 4.2 & 5.3 \\
\hline L Barts & 0.0 & 0 & & & & & \\
\hline L Guys ${ }^{c}$ & 0.0 & 0 & & & & & \\
\hline L Kings & 0.0 & 0 & & & & & \\
\hline L Rfree & 99.9 & 652 & 5.0 & 0.8 & 5 & 4.4 & 5.5 \\
\hline L St.G & 0.0 & 0 & & & & & \\
\hline L West & 0.0 & 0 & & & & & \\
\hline Leeds & 100.0 & 485 & 5.2 & 0.7 & 5.2 & 4.7 & 5.7 \\
\hline Leic & 100.0 & 882 & 5.0 & 0.8 & 4.9 & 4.4 & 5.4 \\
\hline Liv Ain & 0.0 & 0 & & & & & \\
\hline Liv Roy & 0.0 & 0 & & & & & \\
\hline M RI & 0.0 & 0 & & & & & \\
\hline Middlbr & 100.0 & 310 & 4.9 & 0.7 & 4.8 & 4.4 & 5.3 \\
\hline Newc & 0.0 & 0 & & & & & \\
\hline Norwch & 99.7 & 301 & 5.2 & 0.6 & 5.2 & 4.8 & 5.6 \\
\hline Nottm & 99.7 & 364 & 4.9 & 0.7 & 4.9 & 4.5 & 5.3 \\
\hline Oxford & 100.0 & 401 & 5.0 & 0.7 & 4.9 & 4.5 & 5.4 \\
\hline Plymth & 99.2 & 127 & 4.7 & 0.8 & 4.7 & 4.2 & 5.2 \\
\hline
\end{tabular}


Table 8.13. Continued

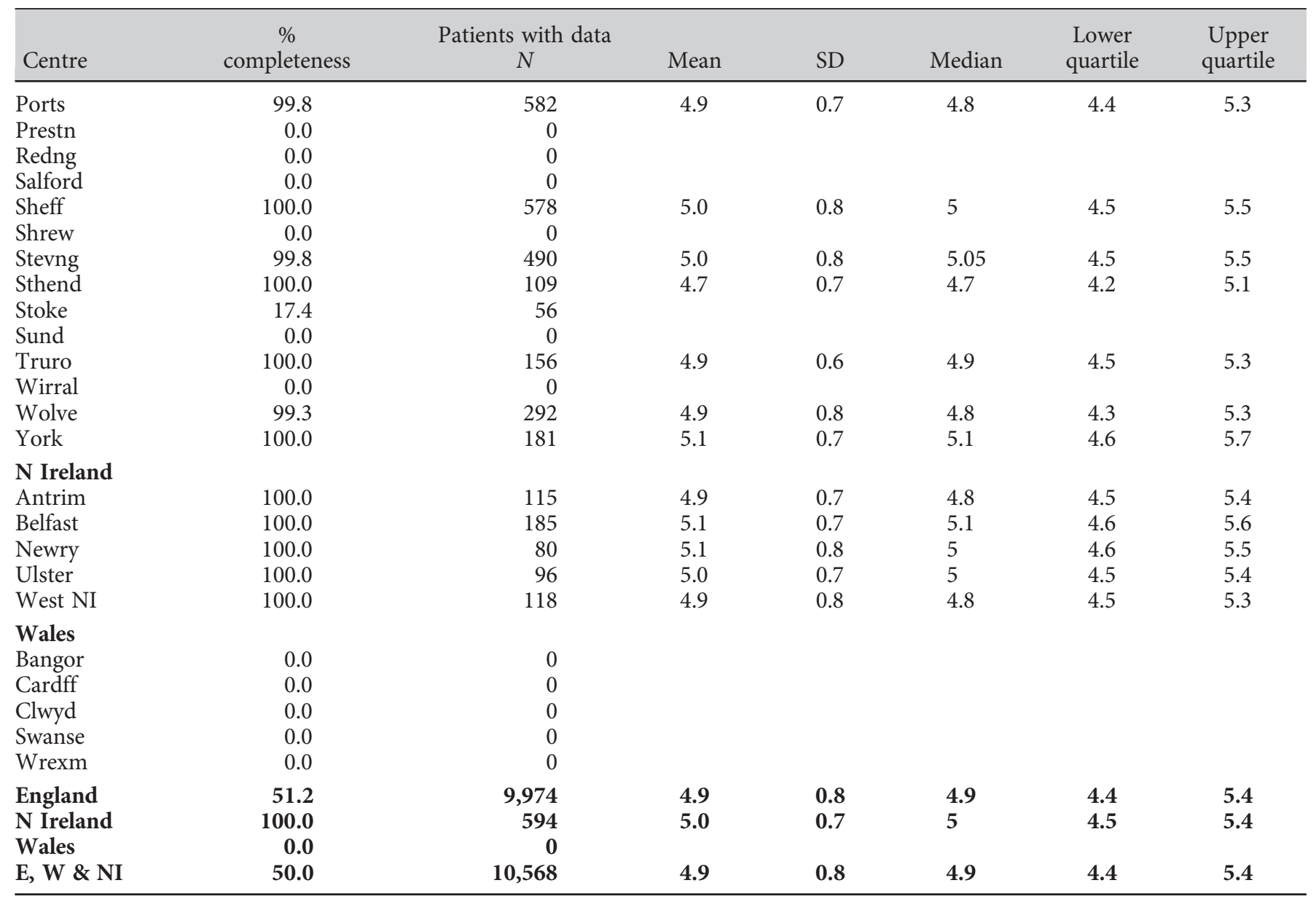

Blank cells: centres excluded from analysis due to low patient numbers or poor data completeness

${ }^{a}$ Cambridge renal centre was unable to submit patient-level data for 2016

${ }^{\mathrm{b}}$ Carlisle and Colchester renal centres submitted potassium data rounded to unit in HD patients, and were therefore excluded from this analysis

${ }^{c}$ Coventry and London Guys renal centres returned potassium data post-haemodialysis and were therefore excluded from this analysis

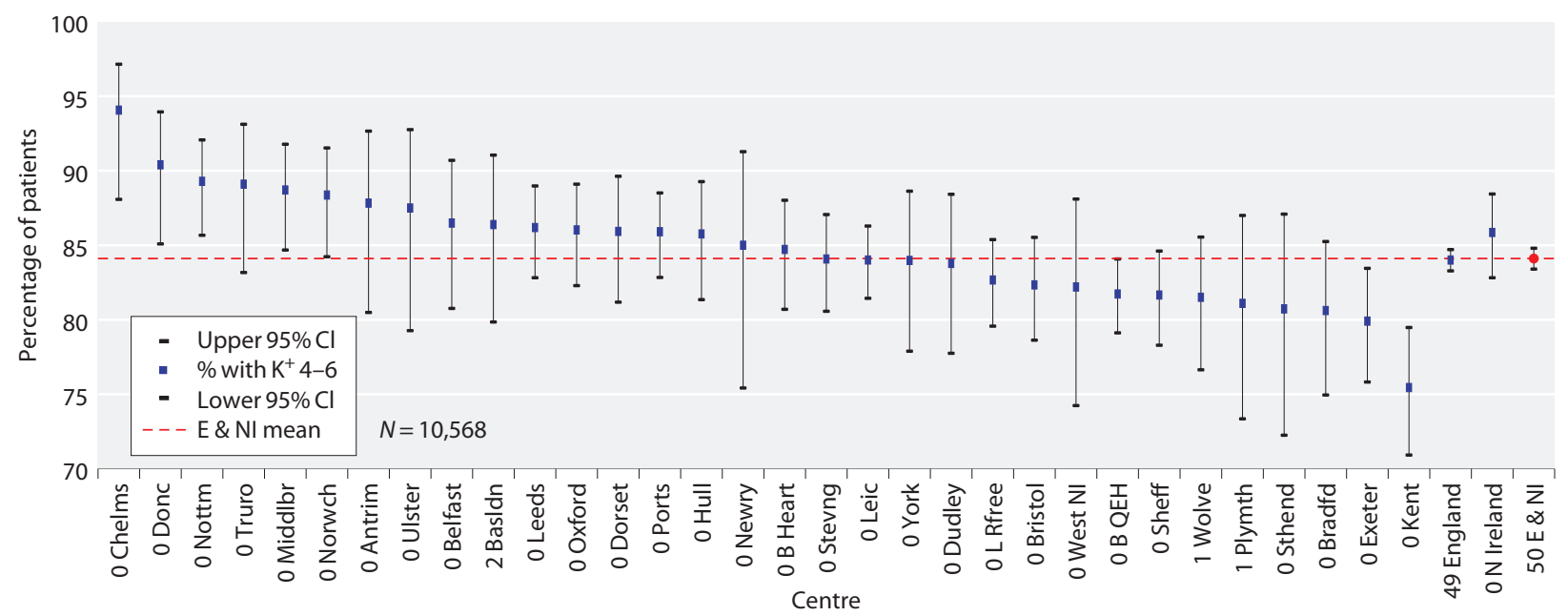

Fig. 8.15. Percentage of haemodialysis patients with serum potassium within range (4-6 mmol/L) by centre in 2016 


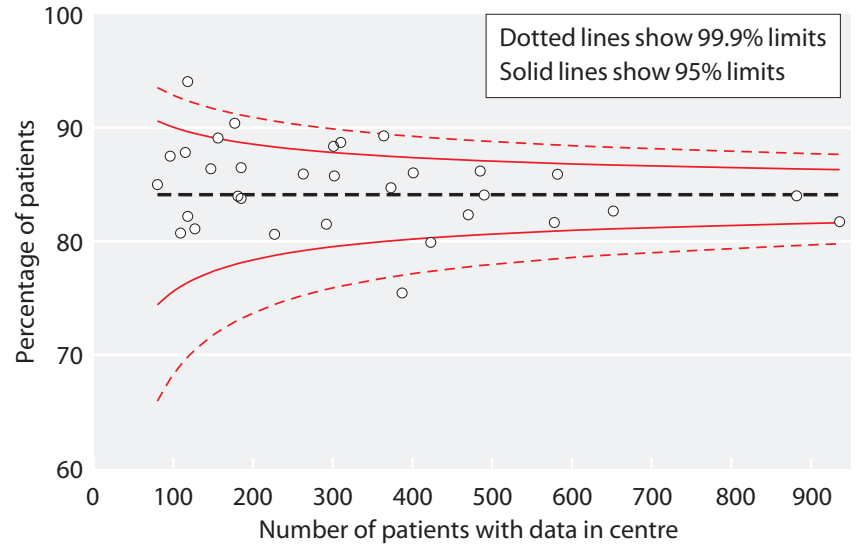

Fig. 8.16. Funnel plot for percentage of haemodialysis patients within range for serum potassium $(4-6 \mathrm{mmol} / \mathrm{L})$ by centre in 2016

confidence interval limits. The serum potassium measurement will be particularly sensitive to differences in the timing and technique of sample processing by centre.

\section{Discussion}

Observational data continues to accumulate linking disordered calcium, phosphate and PTH levels with higher mortality in dialysis patients [10-16]. Despite this, trial data on specific target values or the best treatment approaches are lacking as reflected in recently published international guidelines [6]. The guidelines re-enforce the importance in identifying trends in parameters rather than reacting to isolated measurements and to appreciate the complex interdependency of parameters.

This chapter presents the results of mineral bone disease management for patients established on regular dialysis in the UK. Over the last decade there have been modest improvements in the attainment of target measures. In the latest analysis, a stable proportion of patients with all bone parameters within target range masks higher levels of hyperphosphataemia with improvement in attainment of target PTH. Increased

Table 8.14. Percentage of haemodialysis patients within, below and above the range for serum potassium (4-6 mmol/L) by centre in 2016

\begin{tabular}{|c|c|c|c|c|c|c|}
\hline Centre & $N$ & $\begin{array}{l}\% \text { potassium } \\
4-6 \mathrm{mmol} / \mathrm{L}\end{array}$ & $\begin{array}{l}\text { Lower } \\
95 \% \text { CI }\end{array}$ & $\begin{array}{l}\text { Upper } \\
95 \% \text { CI }\end{array}$ & $\begin{array}{l}\% \text { potassium } \\
<4 \mathrm{mmol} / \mathrm{L}\end{array}$ & $\begin{array}{c}\% \text { potass } \\
>6 \mathrm{~mm}\end{array}$ \\
\hline \multicolumn{7}{|l|}{ England } \\
\hline B Heart & 373 & 84.7 & 80.7 & 88.0 & 9.4 & 5.9 \\
\hline B QEH & 936 & 81.7 & 79.1 & 84.1 & 11.4 & 6.8 \\
\hline Basldn & 147 & 86.4 & 79.9 & 91.1 & 10.2 & 3.4 \\
\hline Bradfd & 227 & 80.6 & 75.0 & 85.3 & 15.9 & 3.5 \\
\hline Bristol & 470 & 82.3 & 78.6 & 85.5 & 15.5 & 2.1 \\
\hline Chelms & 118 & 94.1 & 88.1 & 97.2 & 2.5 & 3.4 \\
\hline Donc & 177 & 90.4 & 85.1 & 94.0 & 6.2 & 3.4 \\
\hline Dorset & 263 & 85.9 & 81.2 & 89.6 & 8.8 & 5.3 \\
\hline Dudley & 185 & 83.8 & 77.8 & 88.4 & 7.0 & 9.2 \\
\hline Exeter & 423 & 79.9 & 75.8 & 83.5 & 18.0 & 2.1 \\
\hline Hull & 302 & 85.8 & 81.4 & 89.3 & 10.9 & 3.3 \\
\hline Kent & 387 & 75.5 & 70.9 & 79.5 & 19.1 & 5.4 \\
\hline L Rfree & 652 & 82.7 & 79.6 & 85.4 & 10.4 & 6.9 \\
\hline Leeds & 485 & 86.2 & 82.8 & 89.0 & 2.5 & 11.3 \\
\hline Leic & 882 & 84.0 & 81.4 & 86.3 & 8.5 & 7.5 \\
\hline Middlbr & 310 & 88.7 & 84.7 & 91.8 & 6.8 & 4.5 \\
\hline Norwch & 301 & 88.4 & 84.2 & 91.5 & 2.0 & 9.6 \\
\hline Nottm & 364 & 89.3 & 85.7 & 92.1 & 5.5 & 5.2 \\
\hline Oxford & 401 & 86.0 & 82.3 & 89.1 & 6.5 & 7.5 \\
\hline Plymth & 127 & 81.1 & 73.4 & 87.0 & 15.8 & 3.2 \\
\hline Ports & 582 & 85.9 & 82.8 & 88.5 & 9.5 & 4.6 \\
\hline Sheff & 578 & 81.7 & 78.3 & 84.6 & 9.0 & 9.3 \\
\hline Stevng & 490 & 84.1 & 80.6 & 87.1 & 6.7 & 9.2 \\
\hline Sthend & 109 & 80.7 & 72.3 & 87.1 & 16.5 & 2.8 \\
\hline Truro & 156 & 89.1 & 83.2 & 93.1 & 7.1 & 3.9 \\
\hline Wolve & 292 & 81.5 & 76.6 & 85.6 & 12.0 & 6.5 \\
\hline York & 181 & 84.0 & 77.9 & 88.6 & 2.8 & 13.3 \\
\hline
\end{tabular}


Table 8.14. Continued

\begin{tabular}{|c|c|c|c|c|c|c|}
\hline Centre & $N$ & $\begin{array}{l}\% \text { potassium } \\
4-6 \mathrm{mmol} / \mathrm{L}\end{array}$ & $\begin{array}{l}\text { Lower } \\
95 \% \text { CI }\end{array}$ & $\begin{array}{l}\text { Upper } \\
95 \% \text { CI }\end{array}$ & $\begin{array}{l}\% \text { potassium } \\
<4 \mathrm{mmol} / \mathrm{L}\end{array}$ & $\begin{array}{l}\% \text { potassium } \\
>6 \mathrm{mmol} / \mathrm{L}\end{array}$ \\
\hline \multicolumn{7}{|l|}{ N Ireland } \\
\hline Antrim & 115 & 87.8 & 80.5 & 92.7 & 7.0 & 5.2 \\
\hline Belfast & 185 & 86.5 & 80.8 & 90.7 & 4.3 & 9.2 \\
\hline Newry & 80 & 85.0 & 75.4 & 91.3 & 3.8 & 11.3 \\
\hline Ulster & 96 & 87.5 & 79.3 & 92.8 & 4.2 & 8.3 \\
\hline West NI & 118 & 82.2 & 74.2 & 88.1 & 7.6 & 10.2 \\
\hline England & 9,974 & 84.0 & 83.3 & 84.7 & 9.7 & 6.3 \\
\hline N Ireland & 594 & 85.9 & 82.8 & 88.4 & 5.4 & 8.8 \\
\hline Wales & O & & & & & \\
\hline $\mathrm{E}, \mathrm{W} \& \mathrm{NI}$ & 10,568 & 84.1 & 83.4 & 84.8 & 9.4 & 6.5 \\
\hline
\end{tabular}

Centres missing from the table were excluded from analysis due to low patient numbers or poor data completeness

hyperphosphataemia was seen across the majority of centres although there continued to be significant inter and intra centre variation in the attainment of target measures in part reflecting the challenge of managing the varied CKD-MBD phenotypes $[6,13]$. As previously described, there were problems related to variations in calcium and PTH measurements between centres [17]. Comorbidity, dialysis dose and dialysate concentrations, as well as the use of phosphate binders, calcium mimetics and vitamin $\mathrm{D}$ analogues are also likely to be significant confounding variables at the patient level. The hope is that the expanded dataset will allow adjustment for these covariates in the near future.

Serum bicarbonate levels have not changed significantly compared with recent years, but there remained marked variation between centres in HD patients. The UKRR has previously conducted a limited survey [18] into the possible underlying causes of serum bicarbonate variation. The study examined measures of sample processing and of dialysis treatment. It did not adjust for case-mix and was unable to detect any significant differences between centres. Studies have identified an increased risk of death stratified by a reduced pre-dialysis serum bicarbonate level $(<17 \mathrm{mmol} / \mathrm{L})$ or with raised levels $(>27 \mathrm{mmol} / \mathrm{L})$ [19-21], as well as with raised dialysate bicarbonate concentrates [11]. Future analysis of management of acidosis will have to re-explore the factors associated with an increased trend in developing alkalosis in HD patients.

Sufficient data were received from renal centres for the first time to analyse pre-dialysis potassium levels. Observational data has shown that pre-dialysis potassium levels both above $6.0 \mathrm{mmol} / \mathrm{L}$ and below $4.0 \mathrm{mmol} / \mathrm{L}$ have been associated with higher mortality thus forming the basis for the current guideline target range [3, 22-23]. More recent analysis of the DOPPS data has shown, that after adjustment for patient factors including nutritional indicators, only higher potassium levels remained associated with higher mortality. Of the samples collected, $84.1 \%$ were within the target range which is slightly higher than the international data (81\%) which included UK data [24]. Serum potassium levels are likely to be particularly sensitive to differences in the timing and processing of samples as well as differences in case-mix. Inter and intra centre variability therefore needs to be interpreted with caution. The current analysis used data collected before a 'short-gap' dialysis session in line with guidelines but in future it is planned to also analyse potassium collected before a 'long-gap' session if data completeness permits.

Conflicts of interest: the authors declare no conflict of interest

\section{References}

1 Renal Association. Clinical Practice Guidelines. http://www.renal.org/ guidelines/currentguidelines

2 Steddon S, Sharples E. Renal Association Clinical Practice Guideline. CKD-Mineral and Bone Disorders, 2015. http://www.renal.org/docs/ default-source/default-document-library/ckd-mineral-and-bone-disorders(ckd-mbd)204ca231181561659443ff000014d4d8.pdf?sfvrsn=0

3 Mactier R, Hoenich N, Breen C. Renal Association Clinical Practice Guideline Haemodialysis, 2009. Nephron Clin Pract 2011; 118(suppl 1):c241-c286

4 Woodrow G, Davies S. Renal Association Clinical Practice Guideline on Peritoneal Dialysis Nephron Clin Pract 2011;118(suppl 1):c287-c310

5 Holt S, Goldsmith D, Renal Association Clinical Practice Guideline on Cardiovascular Disease in CKD. Nephron Clin Pract 2011; 118(suppl 1):c125-c144

6 Kidney Disease: Improving Global Outcomes (KDIGO) CKD-MBD Update Work Group. KDIGO 2017 Clinical Practice Guideline Update 
for the Diagnosis, Evaluation, Prevention, and Treatment of Chronic Kidney Disease-Mineral and Bone Disorder (CKD-MBD). Kidney Int Suppl. 2017;7:1-59

7 Ansell D, Tomson CRV, Chapter 15 UK Renal Registry Annual Report: U.K. Renal Registry, UKRR database, validation and methodology. Nephron Clin Pract. 2009. 111(Suppl 1):c277-85

8 Morton AR, Garland JS, Holden RM: Is the calcium correct? Measuring serum calcium in dialysis patients. Semin Dial. 2010. 23(3):283289

9 Spiegelhalter DJ: Funnel plots for comparing institutional performance. Statistics in Medicine 2005;24:1185-1202

10 Noordzij M, Korevaar JC, Bos WJ, Boeschoten EW, Dekker FW, Bossuyt PM, Krediet RT: Mineral metabolism and cardiovascular morbidity and mortality risk: peritoneal dialysis patients compared with haemodialysis patients. Nephrol Dial Transplant 2006;21:2513-2520

11 Kalantar-Zadeh K, Kuwae N, Regidor DL, Kovesdy CP, Kilpatrick RD, Shinaberger CS, McAllister CJ, Budoff MJ, Salusky IB, Kopple JD: Survival predictability of time-varying indicators of bone disease in maintenance hemodialysis patients. Kidney Int 2006;70:771-780

12 Tentori F, Blayney MJ, Albert JM, Gillespie BW, Kerr PG, Bommer J, Young EW, Akizawa T, Akiba T, Pisoni RL, Robinson BM, Port FK: Mortality risk for dialysis patients with different levels of serum calcium, phosphorus, and PTH: the Dialysis Outcomes and Practice Patterns Study (DOPPS). Am J Kidney Dis 2008;52:519-530

13 Block GA, Kilpatrick RD, Lowe KA, Wang W, Danese MD: CKDmineral and bone disorder and risk of death and cardiovascular hospitalization in patients on hemodialysis. Clin J Am Soc Nephrol 2013;8:2132-2140

14 Danese MD, Belozeroff V, Smirnakis K, Rothman KJ: Consistent control of mineral and bone disorder in incident hemodialysis patients. Clin J Am Soc Nephrol 2008;3:1423-1429

15 Chertow GM, Block GA, Correa-Rotter R, et al. Effect of cinacalcet on cardiovascular disease in patients undergoing dialysis. N Engl J Med. 2012;367:2482-2494

16 Fernandez-Martin JL, Martinez-Camblor P, Dionisi MP, et al. Improvement of mineral and bone metabolism markers is associated with better survival in haemodialysis patients: the COSMOS study. Nephrol Dia Transplant. 2015;30:1542-1551

17 Shaw C, Nicholas J, Pitcher D, Dawnay A: UK Renal Registry 17th Annual Report: Chapter 8 Biochemical Variables amongst UK Adult Dialysis Patients in 2013: National and Centre-specific Analyses. Nephron 2015;129(suppl 1):169-208

18 Ansell D, Feest TG: Renal registry 7th annual report. Chapter 6: Adequacy of haemodialysis and serum bicarbonate, Renal registry 7 th annual report. Chapter 6: Adequacy of haemodialysis and serum bicarbonate. 2004, pp 59-86

19 Wu DY, Shinaberger CS, Regidor DL, McAllister CJ, Kopple JD, Kalantar-Zadeh K: Association between serum bicarbonate and death in hemodialysis patients: Is it better to be acidotic or alkalotic? Clinical Journal of the American Society of Nephrology 2006;1:70-78

20 Lowrie EG, Lew NL: Death risk in hemodialysis patients: the predictive value of commonly measured variables and an evaluation of death rate differences between facilities. American Journal of Kidney Diseases 1990;15:458-482

21 Bommer J, Locatelli F, Satayathum S, Keen ML, Goodkin DA, Saito A, Akiba T, Port FK, Young EW: Association of predialysis serum bicarbonate levels with risk of mortality and hospitalization in the Dialysis Outcomes and Practice Patterns Study (DOPPS). Am J Kidney Dis 2004;44:661-671

22 Kovesday CP, Regidor DL, Mehorta R et al. Serum and dialysate potasium concentrations and survival in haemodialysis patients. Clin J Am Soc Nephrol 2007;2:999-1007

23 Lowrie EG, Teng M, Lew NL et al. Toward a continuous quality improvement paradigm for hemodialysis providers with preliminary suggestions for clinical practice monitoring and measurement. Hemodial Int 2003;7:28-51

24 Karaboyas A, Zee J, Brunelli SM, Usvyat LA, Weiner DE, Maddux FW, Nissenson AR, Jadoul M, Locatelli F, Winkelmayer WC, Port FK, Robinson BM, Tentori F, Dialysate Potassium, Serum Potassium, Mortality, and Arrhythmia Events in Hemodialysis: Results From the Dialysis Outcomes and Practice Patterns Study (DOPPS), American Journal of Kidney Diseases 2017;69(2):266-277 


\section{Appendix 1 Attainment of individual standard for adjusted calcium, phosphate and PTH}

This appendix includes analyses of the individual mineral bone measures that are included in the composite audit measure, namely adjusted calcium, phosphate and PTH within the recommended target ranges.

\section{Adjusted calcium}

In 2016, the following RA clinical practice guideline regarding calcium management was applicable:
Guideline 2.2 CKD-MBD: Serum calcium in dialysis patients (stage 5D)

'We suggest that serum calcium, adjusted for albumin concentration, should be maintained within the normal reference range for the laboratory used, measured before a "short-gap" dialysis session in haemodialysis patients. Ideally, adjusted serum calcium should be maintained between 2.2 and $2.5 \mathrm{mmol} / \mathrm{L}$, with avoidance of hypercalcaemic episodes (2D)' [2]

In 2016, data from 22,552 HD and 3,006 PD patients across the UK were available for serum adjusted calcium

Haemodialysis

Table 8.15. Summary statistics for adjusted calcium in haemodialysis patients in 2016

\begin{tabular}{|c|c|c|c|c|c|c|c|}
\hline Centre & $\begin{array}{c}\% \\
\text { completeness }\end{array}$ & $\begin{array}{c}\text { Patients with } \\
\text { data } N\end{array}$ & Mean & $\mathrm{SD}$ & Median & $\begin{array}{c}\text { Lower } \\
\text { quartile }\end{array}$ & $\begin{array}{l}\text { Upper } \\
\text { quartile }\end{array}$ \\
\hline \multicolumn{8}{|l|}{ England } \\
\hline B Heart & 100.0 & 373 & 2.4 & 0.2 & 2.4 & 2.3 & 2.5 \\
\hline B QEH & 99.7 & 935 & 2.3 & 0.2 & 2.3 & 2.2 & 2.4 \\
\hline Basldn & 98.0 & 147 & 2.4 & 0.2 & 2.4 & 2.3 & 2.5 \\
\hline Bradfd & 99.1 & 226 & 2.4 & 0.1 & 2.4 & 2.4 & 2.5 \\
\hline Brightn & 99.8 & 418 & 2.4 & 0.2 & 2.3 & 2.2 & 2.4 \\
\hline Bristol & 100.0 & 470 & 2.4 & 0.2 & 2.4 & 2.3 & 2.5 \\
\hline \multicolumn{8}{|l|}{ Camb* } \\
\hline Carlis & 100.0 & 88 & 2.3 & 0.2 & 2.3 & 2.2 & 2.4 \\
\hline Carsh & 99.7 & 772 & 2.3 & 0.2 & 2.3 & 2.2 & 2.4 \\
\hline Chelms & 100.0 & 118 & 2.3 & 0.2 & 2.3 & 2.2 & 2.4 \\
\hline Colchr & 83.6 & 92 & 2.4 & 0.1 & 2.4 & 2.3 & 2.5 \\
\hline Covnt & 99.7 & 345 & 2.3 & 0.2 & 2.3 & 2.2 & 2.4 \\
\hline Derby & 100.0 & 227 & 2.4 & 0.1 & 2.4 & 2.3 & 2.5 \\
\hline Donc & 100.0 & 177 & 2.3 & 0.2 & 2.3 & 2.3 & 2.4 \\
\hline Dorset & 100.0 & 263 & 2.3 & 0.2 & 2.3 & 2.2 & 2.4 \\
\hline Dudley & 100.0 & 185 & 2.3 & 0.2 & 2.3 & 2.2 & 2.4 \\
\hline Exeter & 100.0 & 423 & 2.3 & 0.1 & 2.3 & 2.2 & 2.4 \\
\hline Glouc & 100.0 & 228 & 2.4 & 0.2 & 2.3 & 2.3 & 2.5 \\
\hline Hull & 100.0 & 302 & 2.4 & 0.2 & 2.4 & 2.3 & 2.5 \\
\hline Ipswi & 99.3 & 135 & 2.4 & 0.2 & 2.4 & 2.2 & 2.5 \\
\hline Kent & 100.0 & 387 & 2.4 & 0.2 & 2.4 & 2.3 & 2.5 \\
\hline L Barts & 99.8 & 953 & 2.3 & 0.2 & 2.3 & 2.2 & 2.4 \\
\hline L Guys & 99.8 & 643 & 2.4 & 0.2 & 2.4 & 2.3 & 2.4 \\
\hline L Kings & 99.8 & 544 & 2.3 & 0.2 & 2.3 & 2.2 & 2.4 \\
\hline L Rfree & 99.9 & 652 & 2.3 & 0.2 & 2.3 & 2.2 & 2.4 \\
\hline L St.G & 96.9 & 314 & 2.3 & 0.2 & 2.3 & 2.2 & 2.4 \\
\hline L West & 85.6 & 1,180 & 2.3 & 0.2 & 2.3 & 2.2 & 2.5 \\
\hline Leeds & 100.0 & 485 & 2.4 & 0.2 & 2.4 & 2.3 & 2.5 \\
\hline Leic & 99.9 & 881 & 2.3 & 0.2 & 2.3 & 2.2 & 2.4 \\
\hline Liv Ain & 97.1 & 170 & 2.4 & 0.2 & 2.4 & 2.3 & 2.4 \\
\hline Liv Roy & 98.0 & 336 & 2.3 & 0.2 & 2.3 & 2.2 & 2.5 \\
\hline M RI & 94.1 & 458 & 2.4 & 0.2 & 2.4 & 2.3 & 2.5 \\
\hline Middlbr & 100.0 & 310 & 2.3 & 0.2 & 2.3 & 2.1 & 2.4 \\
\hline
\end{tabular}


Table 8.15. Continued

\begin{tabular}{|c|c|c|c|c|c|c|c|}
\hline Centre & $\begin{array}{c}\% \\
\text { completeness }\end{array}$ & $\begin{array}{l}\text { Patients with } \\
\quad \text { data } N\end{array}$ & Mean & SD & Median & $\begin{array}{l}\text { Lower } \\
\text { quartile }\end{array}$ & $\begin{array}{l}\text { Upper } \\
\text { quartile }\end{array}$ \\
\hline Newc & 100.0 & 287 & 2.3 & 0.2 & 2.3 & 2.2 & 2.4 \\
\hline Norwch & 99.7 & 301 & 2.4 & 0.2 & 2.4 & 2.3 & 2.5 \\
\hline Nottm & 99.7 & 364 & 2.3 & 0.2 & 2.3 & 2.2 & 2.4 \\
\hline Oxford & 100.0 & 401 & 2.4 & 0.2 & 2.3 & 2.3 & 2.4 \\
\hline Plymth & 99.2 & 127 & 2.3 & 0.2 & 2.3 & 2.2 & 2.4 \\
\hline Ports & 99.8 & 582 & 2.3 & 0.2 & 2.3 & 2.2 & 2.4 \\
\hline Prestn & 93.8 & 498 & 2.3 & 0.2 & 2.3 & 2.2 & 2.4 \\
\hline Redng & 100.0 & 288 & 2.3 & 0.2 & 2.3 & 2.2 & 2.4 \\
\hline Salford & 97.5 & 353 & 2.3 & 0.2 & 2.3 & 2.2 & 2.4 \\
\hline Sheff & 99.8 & 577 & 2.3 & 0.2 & 2.3 & 2.2 & 2.4 \\
\hline Shrew & 100.0 & 189 & 2.4 & 0.2 & 2.4 & 2.3 & 2.5 \\
\hline Stevng & 99.8 & 490 & 2.4 & 0.2 & 2.3 & 2.2 & 2.5 \\
\hline Sthend & 100.0 & 109 & 2.4 & 0.2 & 2.4 & 2.3 & 2.6 \\
\hline Stoke & 98.8 & 318 & 2.4 & 0.2 & 2.4 & 2.3 & 2.5 \\
\hline Sund & 100.0 & 223 & 2.3 & 0.2 & 2.2 & 2.1 & 2.3 \\
\hline Truro & 100.0 & 156 & 2.3 & 0.2 & 2.3 & 2.2 & 2.4 \\
\hline Wirral & 99.4 & 178 & 2.3 & 0.2 & 2.3 & 2.2 & 2.4 \\
\hline Wolve & 99.0 & 291 & 2.4 & 0.2 & 2.4 & 2.3 & 2.5 \\
\hline York & 100.0 & 181 & 2.4 & 0.1 & 2.4 & 2.3 & 2.5 \\
\hline \multicolumn{8}{|l|}{ N Ireland } \\
\hline Antrim & 100.0 & 115 & 2.4 & 0.2 & 2.4 & 2.3 & 2.5 \\
\hline Belfast & 100.0 & 185 & 2.3 & 0.2 & 2.3 & 2.2 & 2.4 \\
\hline Newry & 100.0 & 80 & 2.4 & 0.2 & 2.4 & 2.3 & 2.5 \\
\hline Ulster & 99.0 & 95 & 2.5 & 0.1 & 2.5 & 2.4 & 2.6 \\
\hline West NI & 100.0 & 118 & 2.3 & 0.1 & 2.3 & 2.2 & 2.4 \\
\hline \multicolumn{8}{|l|}{ Scotland } \\
\hline Abrdn & 99.5 & 217 & 2.4 & 0.2 & 2.4 & 2.3 & 2.5 \\
\hline Airdrie & 100.0 & 173 & 2.4 & 0.2 & 2.4 & 2.3 & 2.5 \\
\hline D \& Gall & 97.9 & 46 & 2.3 & 0.2 & 2.3 & 2.2 & 2.4 \\
\hline Dundee & 98.8 & 164 & 2.4 & 0.2 & 2.4 & 2.3 & 2.5 \\
\hline Edinb & 100.0 & 269 & 2.4 & 0.2 & 2.4 & 2.3 & 2.5 \\
\hline Glasgw & 100.0 & 537 & 2.4 & 0.2 & 2.4 & 2.3 & 2.5 \\
\hline Inverns & 80.0 & 68 & 2.4 & 0.2 & 2.3 & 2.3 & 2.4 \\
\hline Klmarnk & 100.0 & 128 & 2.4 & 0.2 & 2.4 & 2.3 & 2.6 \\
\hline Krkcldy & 100.0 & 135 & 2.4 & 0.2 & 2.3 & 2.3 & 2.4 \\
\hline \multicolumn{8}{|l|}{ Wales } \\
\hline Bangor & 100.0 & 68 & 2.3 & 0.2 & 2.3 & 2.2 & 2.4 \\
\hline Cardff & 99.8 & 480 & 2.4 & 0.2 & 2.4 & 2.3 & 2.5 \\
\hline Clwyd & 100.0 & 68 & 2.4 & 0.1 & 2.4 & 2.3 & 2.5 \\
\hline Swanse & 100.0 & 343 & 2.4 & 0.2 & 2.4 & 2.3 & 2.4 \\
\hline Wrexm & 100.0 & 113 & 2.3 & 0.1 & 2.3 & 2.2 & 2.4 \\
\hline England & 98.3 & 19,150 & 2.3 & 0.2 & 2.3 & 2.2 & 2.4 \\
\hline $\mathrm{N}$ Ireland & 99.8 & 593 & 2.4 & 0.2 & 2.3 & 2.2 & 2.5 \\
\hline Scotland & 98.8 & 1,737 & 2.4 & 0.2 & 2.4 & 2.3 & 2.5 \\
\hline Wales & 99.9 & 1,072 & 2.4 & 0.2 & 2.4 & 2.3 & 2.5 \\
\hline UK & 98.4 & 22,552 & 2.3 & 0.2 & 2.3 & 2.2 & 2.4 \\
\hline
\end{tabular}

${ }^{*}$ Cambridge renal centre was unable to submit calcium data for 2016 
Table 8.16. Percentage of haemodialysis patients within, below and above the range for adjusted calcium (2.2-2.5 mmol/L) in 2016

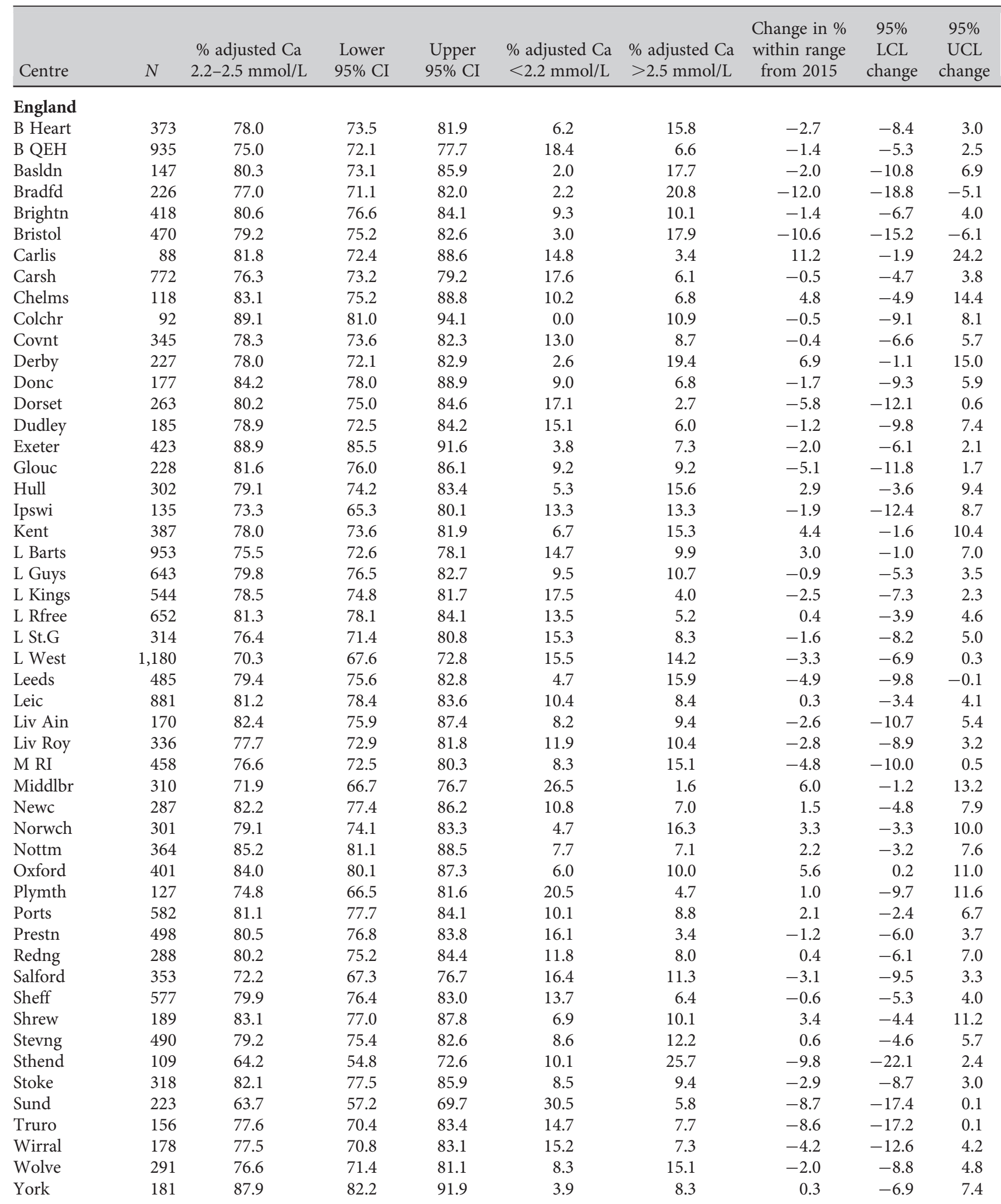


Table 8.16. Continued

\begin{tabular}{|c|c|c|c|c|c|c|c|c|c|}
\hline Centre & $N$ & $\begin{array}{c}\% \text { adjusted Ca } \\
2.2-2.5 \mathrm{mmol} / \mathrm{L}\end{array}$ & $\begin{array}{l}\text { Lower } \\
95 \% \text { CI }\end{array}$ & $\begin{array}{l}\text { Upper } \\
95 \% \text { CI }\end{array}$ & $\begin{array}{l}\% \text { adjusted } \mathrm{Ca} \\
<2.2 \mathrm{mmol} / \mathrm{L}\end{array}$ & $\begin{array}{l}\% \text { adjusted } \mathrm{Ca} \\
>2.5 \mathrm{mmol} / \mathrm{L}\end{array}$ & $\begin{array}{c}\text { Change in \% } \\
\text { within range } \\
\text { from } 2015\end{array}$ & $\begin{array}{c}95 \% \\
\text { LCL } \\
\text { change }\end{array}$ & $\begin{array}{c}95 \% \\
\text { UCL } \\
\text { change }\end{array}$ \\
\hline \multicolumn{10}{|l|}{$\mathrm{N}$ Ireland } \\
\hline Antrim & 115 & 83.5 & 75.5 & 89.2 & 7.8 & 8.7 & 5.4 & -4.8 & 15.6 \\
\hline Belfast & 185 & 82.7 & 76.6 & 87.5 & 11.4 & 6.0 & -4.5 & -11.9 & 2.9 \\
\hline Newry & 80 & 82.5 & 72.6 & 89.4 & 10.0 & 7.5 & -12.7 & -22.2 & -3.2 \\
\hline Ulster & 95 & 65.3 & 55.2 & 74.1 & 2.1 & 32.6 & 6.3 & -7.5 & 20.1 \\
\hline West NI & 118 & 84.8 & 77.1 & 90.2 & 11.9 & 3.4 & 10.4 & 0.1 & 20.8 \\
\hline \multicolumn{10}{|l|}{ Scotland } \\
\hline Abrdn & 217 & 75.6 & 69.4 & 80.8 & 7.8 & 16.6 & 3.4 & -5.0 & 11.8 \\
\hline Airdrie & 173 & 81.5 & 75.0 & 86.6 & 7.5 & 11.0 & -0.1 & -8.3 & 8.1 \\
\hline D \& Gall & 46 & 71.7 & 57.2 & 82.8 & 19.6 & 8.7 & -4.3 & -21.9 & 13.3 \\
\hline Dundee & 164 & 76.2 & 69.1 & 82.1 & 4.3 & 19.5 & -7.4 & -16.0 & 1.1 \\
\hline Edinb & 269 & 77.0 & 71.5 & 81.6 & 6.0 & 17.1 & 13.4 & 5.5 & 21.2 \\
\hline Glasgw & 537 & 81.9 & 78.5 & 85.0 & 5.4 & 12.7 & -1.5 & -6.0 & 3.0 \\
\hline Inverns & 68 & 82.4 & 71.4 & 89.7 & 11.8 & 5.9 & 0.5 & -12.0 & 13.0 \\
\hline Klmarnk & 128 & 73.4 & 65.1 & 80.4 & 1.6 & 25.0 & -6.4 & -16.8 & 4.0 \\
\hline Krkcldy & 135 & 82.2 & 74.8 & 87.8 & 8.9 & 8.9 & 2.8 & -6.6 & 12.3 \\
\hline \multicolumn{10}{|l|}{ Wales } \\
\hline Bangor & 68 & 80.9 & 69.8 & 88.6 & 11.8 & 7.4 & 0.1 & -12.7 & 12.9 \\
\hline Cardff & 480 & 78.3 & 74.4 & 81.8 & 6.9 & 14.8 & 2.0 & -3.3 & 7.4 \\
\hline Clwyd & 68 & 88.2 & 78.2 & 94.0 & 2.9 & 8.8 & 6.7 & -4.9 & 18.3 \\
\hline Swanse & 343 & 84.6 & 80.3 & 88.0 & 7.3 & 8.2 & 1.2 & -4.3 & 6.7 \\
\hline Wrexm & 113 & 91.2 & 84.3 & 95.2 & 5.3 & 3.5 & 12.4 & 2.8 & 22.0 \\
\hline England & 19,150 & 78.4 & 77.8 & 79.0 & 11.7 & 9.9 & -0.9 & -1.8 & -0.1 \\
\hline $\mathrm{N}$ Ireland & 593 & 80.4 & 77.1 & 83.4 & 9.1 & 10.5 & 1.0 & -3.6 & 5.6 \\
\hline Scotland & 1,737 & 78.9 & 77.0 & 80.8 & 6.5 & 14.6 & 0.7 & -2.0 & 3.5 \\
\hline Wales & 1,072 & 82.5 & 80.1 & 84.6 & 6.9 & 10.6 & 2.9 & -0.4 & 6.3 \\
\hline UK & 22,552 & 78.7 & 78.2 & 79.2 & 11.0 & 10.3 & -0.6 & -1.3 & 0.2 \\
\hline
\end{tabular}

Centres missing from the table were excluded from analysis due to low patient numbers or poor data completeness

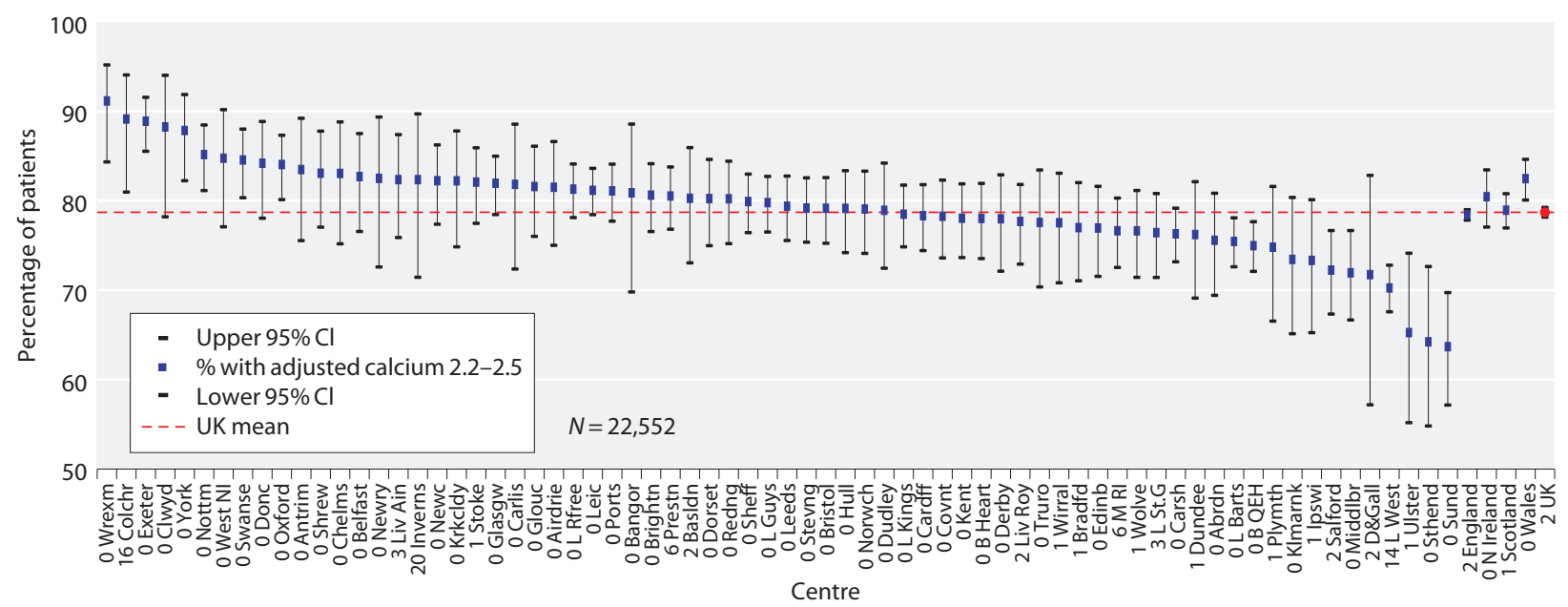

Fig. 8.17. Percentage of haemodialysis patients with adjusted calcium within range $(2.2-2.5 \mathrm{mmol} / \mathrm{L})$ by centre in 2016 


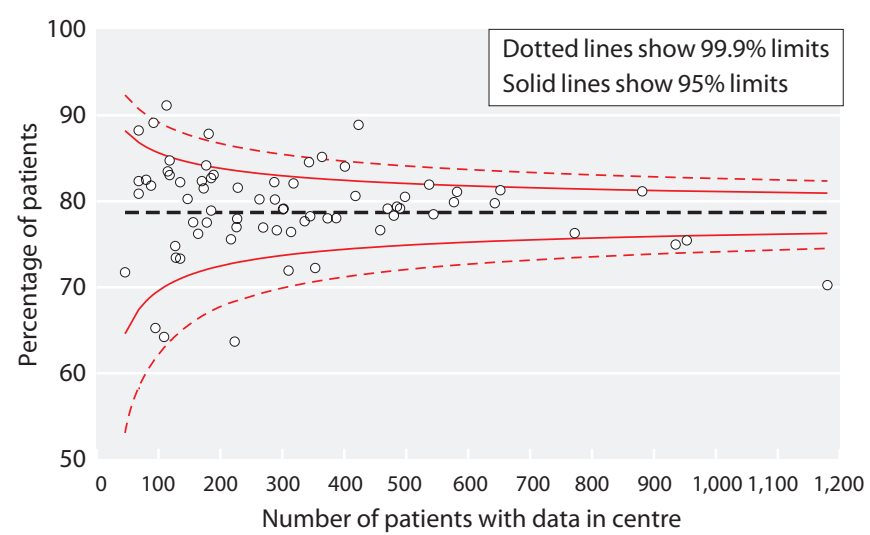

Fig. 8.18. Funnel plot of percentage of haemodialysis patients with adjusted calcium within range $(2.2-2.5 \mathrm{mmol} / \mathrm{L})$ by centre in 2016

analysis. The data were $98.4 \%$ complete for HD patients and $98.1 \%$ complete for PD patients overall, although there was inter-centre variation (tables 8.15, 8.17).

Belfast, Colchester, London West and Preston did not return locally adjusted calcium results for most or all of their patients, whilst Sunderland, Wirral, Liverpool Aintree, Dorset and Portsmouth returned adjusted calcium results for only a proportion of their patients. Hence these data are shown after adjustment using a generic formula, and specific formulae provided some years ago by the laboratories serving Colchester, London West and Preston, have been applied.

Those formulae may not be applicable to the calcium and albumin methods used locally in 2016 and may have over- or under-estimated the adjusted calcium. These centres are served by laboratories that report adjusted calcium results and therefore it is hoped that adjusted calcium values be reported to the UKRR in future.

Of HD patients, $78.7 \%$ (95\% CI 78.2-79.2\%) and of PD patients 79.7\% (95\% CI 78.3-81.1\%) had an adjusted calcium between 2.2-2.5 mmol/L (tables 8.16, 8.18, figures 8.17, 8.19).

The proportion of hypocalcaemic patients in the UK was $11.0 \%$ for $\mathrm{HD}$ and $8.3 \%$ for PD (tables $8.16,8.18$ ). The proportion of hypercalcaemic patients in the UK was $10.3 \%$ for HD and $12.0 \%$ for PD (tables $8.16,8.18$ ).

\section{Peritoneal dialysis}

Table 8.17. Summary statistics for adjusted calcium in peritoneal dialysis patients in 2016

\begin{tabular}{|c|c|c|c|c|c|c|c|}
\hline Centre & $\begin{array}{c}\% \\
\text { completeness }\end{array}$ & $\begin{array}{l}\text { Patients with } \\
\text { data } N\end{array}$ & Mean & SD & Median & $\begin{array}{l}\text { Lower } \\
\text { quartile }\end{array}$ & $\begin{array}{l}\text { Upper } \\
\text { quartile }\end{array}$ \\
\hline \multicolumn{8}{|l|}{ England } \\
\hline B Heart & 100.0 & 72 & 2.3 & 0.2 & 2.3 & 2.2 & 2.4 \\
\hline B QEH & 100.0 & 125 & 2.3 & 0.2 & 2.3 & 2.2 & 2.5 \\
\hline Basldn & 100.0 & 30 & 2.4 & 0.1 & 2.4 & 2.3 & 2.5 \\
\hline Bradfd & 100.0 & 22 & 2.5 & 0.1 & 2.5 & 2.4 & 2.5 \\
\hline Brightn & 100.0 & 56 & 2.4 & 0.2 & 2.4 & 2.3 & 2.5 \\
\hline Bristol & 100.0 & 42 & 2.4 & 0.1 & 2.4 & 2.3 & 2.5 \\
\hline \multicolumn{8}{|l|}{$\mathrm{Camb}^{\mathrm{a}}$} \\
\hline Carlis & 100.0 & 31 & 2.3 & 0.1 & 2.3 & 2.3 & 2.4 \\
\hline Carsh & 92.1 & 93 & 2.3 & 0.2 & 2.3 & 2.2 & 2.4 \\
\hline Chelms & 88.9 & 24 & 2.4 & 0.2 & 2.4 & 2.3 & 2.5 \\
\hline \multicolumn{8}{|l|}{ Colchr ${ }^{\mathrm{b}}$} \\
\hline Covnt & 98.3 & 58 & 2.4 & 0.1 & 2.4 & 2.3 & 2.4 \\
\hline Derby & 100.0 & 71 & 2.5 & 0.1 & 2.5 & 2.4 & 2.5 \\
\hline Donc & 100.0 & 25 & 2.4 & 0.1 & 2.4 & 2.3 & 2.5 \\
\hline Dorset & 100.0 & 33 & 2.3 & 0.2 & 2.3 & 2.2 & 2.4 \\
\hline Dudley & 100.0 & 48 & 2.3 & 0.2 & 2.3 & 2.2 & 2.4 \\
\hline Exeter & 100.0 & 73 & 2.3 & 0.2 & 2.3 & 2.2 & 2.5 \\
\hline Glouc & 97.0 & 32 & 2.4 & 0.2 & 2.4 & 2.3 & 2.5 \\
\hline Hull & 100.0 & 61 & 2.4 & 0.1 & 2.4 & 2.3 & 2.5 \\
\hline Ipswi & 100.0 & 33 & 2.4 & 0.1 & 2.3 & 2.3 & 2.4 \\
\hline Kent & 97.7 & 42 & 2.5 & 0.2 & 2.5 & 2.4 & 2.6 \\
\hline L Barts & 97.8 & 175 & 2.3 & 0.2 & 2.3 & 2.2 & 2.4 \\
\hline L Guys & 100.0 & 32 & 2.4 & 0.1 & 2.4 & 2.3 & 2.5 \\
\hline L Kings & 100.0 & 75 & 2.3 & 0.2 & 2.3 & 2.2 & 2.4 \\
\hline L Rfree & 97.8 & 135 & 2.3 & 0.2 & 2.4 & 2.2 & 2.5 \\
\hline L St.G & 97.3 & 36 & 2.4 & 0.1 & 2.4 & 2.3 & 2.5 \\
\hline L West & 90.6 & 77 & 2.4 & 0.2 & 2.4 & 2.3 & 2.5 \\
\hline
\end{tabular}


Table 8.17. Continued

\begin{tabular}{|c|c|c|c|c|c|c|c|}
\hline Centre & $\begin{array}{c}\% \\
\text { completeness }\end{array}$ & $\begin{array}{l}\text { Patients with } \\
\text { data } N\end{array}$ & Mean & SD & Median & $\begin{array}{l}\text { Lower } \\
\text { quartile }\end{array}$ & $\begin{array}{l}\text { Upper } \\
\text { quartile }\end{array}$ \\
\hline Leeds & 100.0 & 36 & 2.4 & 0.2 & 2.4 & 2.3 & 2.5 \\
\hline Leic & 98.6 & 69 & 2.4 & 0.2 & 2.4 & 2.3 & 2.5 \\
\hline Liv Ain & 100.0 & 23 & 2.4 & 0.1 & 2.3 & 2.3 & 2.4 \\
\hline Liv Roy & 98.4 & 63 & 2.4 & 0.2 & 2.4 & 2.2 & 2.5 \\
\hline M RI & 98.0 & 48 & 2.4 & 0.1 & 2.4 & 2.3 & 2.5 \\
\hline Middlbr & 100.0 & 22 & 2.2 & 0.1 & 2.2 & 2.2 & 2.3 \\
\hline Newc & 97.8 & 45 & 2.4 & 0.2 & 2.4 & 2.3 & 2.5 \\
\hline Norwch & 100.0 & 41 & 2.4 & 0.2 & 2.4 & 2.3 & 2.5 \\
\hline Nottm & 100.0 & 67 & 2.3 & 0.2 & 2.4 & 2.2 & 2.4 \\
\hline Oxford & 100.0 & 80 & 2.4 & 0.1 & 2.4 & 2.3 & 2.5 \\
\hline Plymth & 96.8 & 30 & 2.3 & 0.2 & 2.4 & 2.2 & 2.4 \\
\hline Ports & 98.5 & 66 & 2.4 & 0.2 & 2.4 & 2.3 & 2.4 \\
\hline Prestn & 100.0 & 35 & 2.4 & 0.1 & 2.4 & 2.3 & 2.5 \\
\hline Redng & 100.0 & 44 & 2.4 & 0.1 & 2.4 & 2.3 & 2.5 \\
\hline Salford & 98.9 & 89 & 2.4 & 0.2 & 2.4 & 2.3 & 2.5 \\
\hline Sheff & 100.0 & 47 & 2.3 & 0.1 & 2.3 & 2.2 & 2.4 \\
\hline Shrew & 100.0 & 29 & 2.4 & 0.1 & 2.4 & 2.4 & 2.5 \\
\hline Stevng & 100.0 & 16 & 2.3 & 0.2 & 2.4 & 2.2 & 2.4 \\
\hline Sthend & 100.0 & 24 & 2.4 & 0.2 & 2.4 & 2.3 & 2.5 \\
\hline Stoke & 91.6 & 65 & 2.4 & 0.2 & 2.4 & 2.3 & 2.5 \\
\hline Sund & 100.0 & 17 & 2.3 & 0.2 & 2.3 & 2.2 & 2.3 \\
\hline Truro & 100.0 & 17 & 2.3 & 0.2 & 2.4 & 2.2 & 2.5 \\
\hline Wirral & 100.0 & 15 & 2.4 & 0.1 & 2.3 & 2.2 & 2.4 \\
\hline Wolve & 93.8 & 60 & 2.3 & 0.2 & 2.3 & 2.2 & 2.4 \\
\hline York & 100.0 & 27 & 2.4 & 0.2 & 2.4 & 2.3 & 2.5 \\
\hline \multicolumn{8}{|l|}{ N Ireland } \\
\hline Antrim & 100.0 & 14 & 2.4 & 0.1 & 2.4 & 2.3 & 2.5 \\
\hline Belfast & 100.0 & 22 & 2.4 & 0.2 & 2.4 & 2.3 & 2.5 \\
\hline Newry & 100.0 & 19 & 2.4 & 0.2 & 2.4 & 2.3 & 2.5 \\
\hline Ulster & 100.0 & 5 & & & & & \\
\hline West NI & 100.0 & 9 & & & & & \\
\hline \multicolumn{8}{|l|}{ Scotland } \\
\hline Abrdn & 100.0 & 19 & 2.4 & 0.2 & 2.4 & 2.2 & 2.5 \\
\hline Airdrie & 100.0 & 21 & 2.3 & 0.2 & 2.3 & 2.3 & 2.4 \\
\hline D \& Gall & 100.0 & 10 & 2.4 & 0.2 & 2.4 & 2.3 & 2.4 \\
\hline Dundee & 100.0 & 13 & 2.5 & 0.2 & 2.5 & 2.3 & 2.6 \\
\hline Edinb & 100.0 & 31 & 2.4 & 0.2 & 2.4 & 2.3 & 2.5 \\
\hline Glasgw & 100.0 & 43 & 2.5 & 0.2 & 2.5 & 2.4 & 2.5 \\
\hline Inverns & 33.3 & 3 & & & & & \\
\hline Klmarnk & 96.4 & 27 & 2.4 & 0.2 & 2.4 & 2.3 & 2.5 \\
\hline Krkcldy & 100.0 & 15 & 2.5 & 0.1 & 2.5 & 2.4 & 2.6 \\
\hline \multicolumn{8}{|l|}{ Wales } \\
\hline Bangor & 100.0 & 15 & 2.3 & 0.1 & 2.3 & 2.3 & 2.4 \\
\hline Cardff & 95.5 & 64 & 2.4 & 0.1 & 2.4 & 2.3 & 2.5 \\
\hline Clwyd & 100.0 & 14 & 2.5 & 0.2 & 2.5 & 2.4 & 2.5 \\
\hline Swanse & 100.0 & 58 & 2.4 & 0.2 & 2.4 & 2.3 & 2.5 \\
\hline Wrexm & 100.0 & 28 & 2.4 & 0.2 & 2.4 & 2.3 & 2.5 \\
\hline England & 98.2 & 2,576 & 2.4 & 0.2 & 2.4 & 2.3 & 2.5 \\
\hline $\mathrm{N}$ Ireland & 100.0 & 69 & 2.4 & 0.2 & 2.4 & 2.3 & 2.5 \\
\hline Scotland & 96.3 & 182 & 2.4 & 0.2 & 2.4 & 2.3 & 2.5 \\
\hline Wales & 98.4 & 179 & 2.4 & 0.2 & 2.4 & 2.3 & 2.5 \\
\hline UK & 98.1 & 3,006 & 2.4 & 0.2 & 2.4 & 2.3 & 2.5 \\
\hline
\end{tabular}

Blank cells: centres excluded from analysis due to low patient numbers or poor data completeness ${ }^{a}$ Cambridge renal centre was unable to submit calcium data for 2016

${ }^{\mathrm{b}}$ Colchester - no PD patients 
Table 8.18. Percentage of peritoneal dialysis patients within, below and above the range for adjusted calcium (2.2-2.5 mmol/L) in 2016

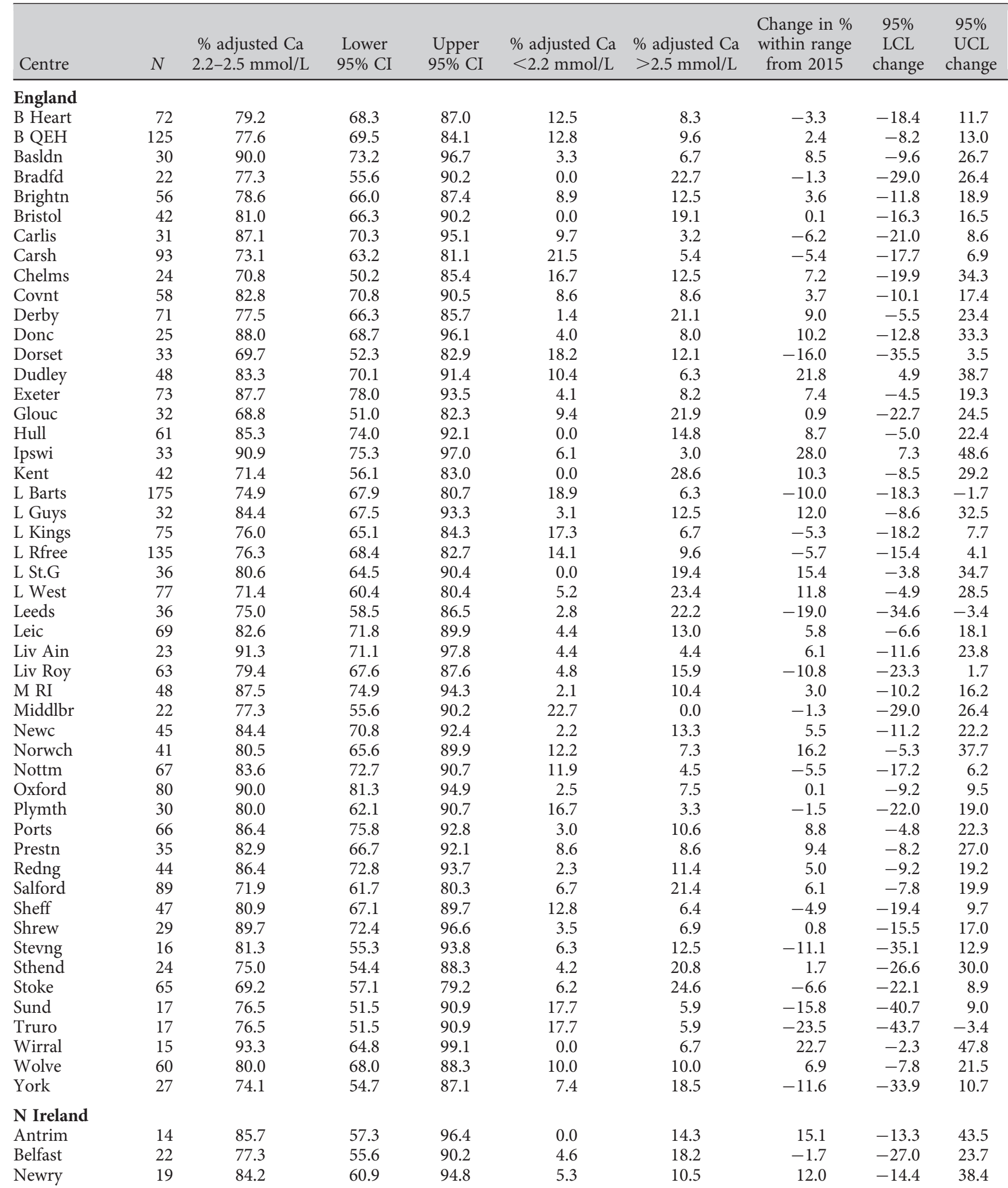


Table 8.18. Continued

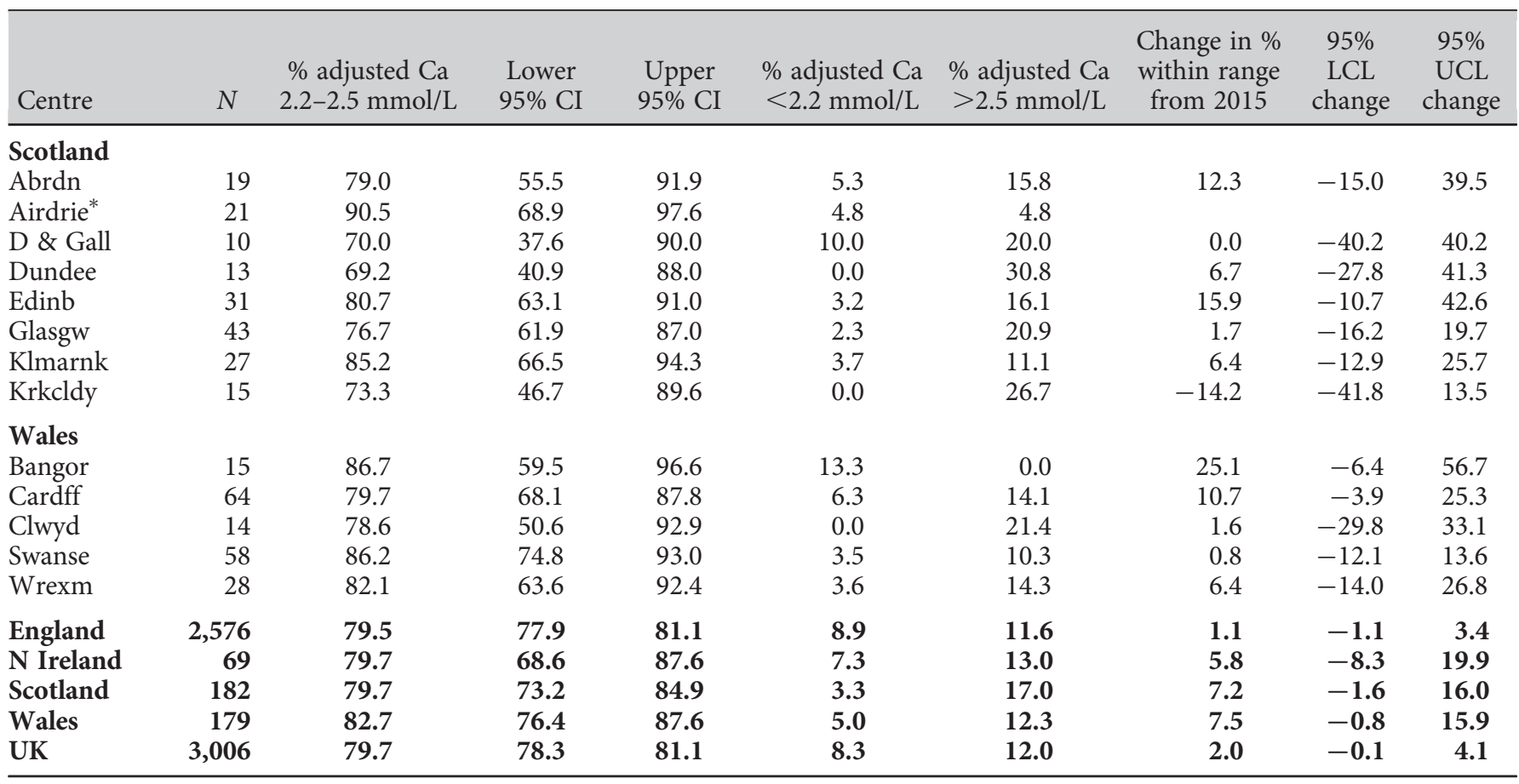

Centres missing from the table were excluded from analysis due to low patient numbers or poor data completeness

*Bank cells indicate no data for 2015

Figure 8.18 presents the funnel plot of HD patients attaining adjusted calcium levels between 2.2 and $2.5 \mathrm{mmol} / \mathrm{L}$ in 2016 . Two centre's results fell below the lower $99.9 \%$ confidence interval: London West and Sunderland. However, data for both centres may be misleading since London West and Sunderland failed to return locally adjusted calcium results on all and half of their HD patients respectively. The percentage of $\mathrm{HD}$ patients with serum calcium within the reference range was significantly higher than the average (above the $99.9 \%$ confidence limit) in Exeter, Nottingham, Wrexham and York.

Figure 8.20 presents the funnel plot of PD patients attaining the adjusted calcium levels between 2.2 and $2.5 \mathrm{mmol} / \mathrm{L}$ in 2016 . Once corrected for centre size, no centre was significantly lower or higher than the national average.

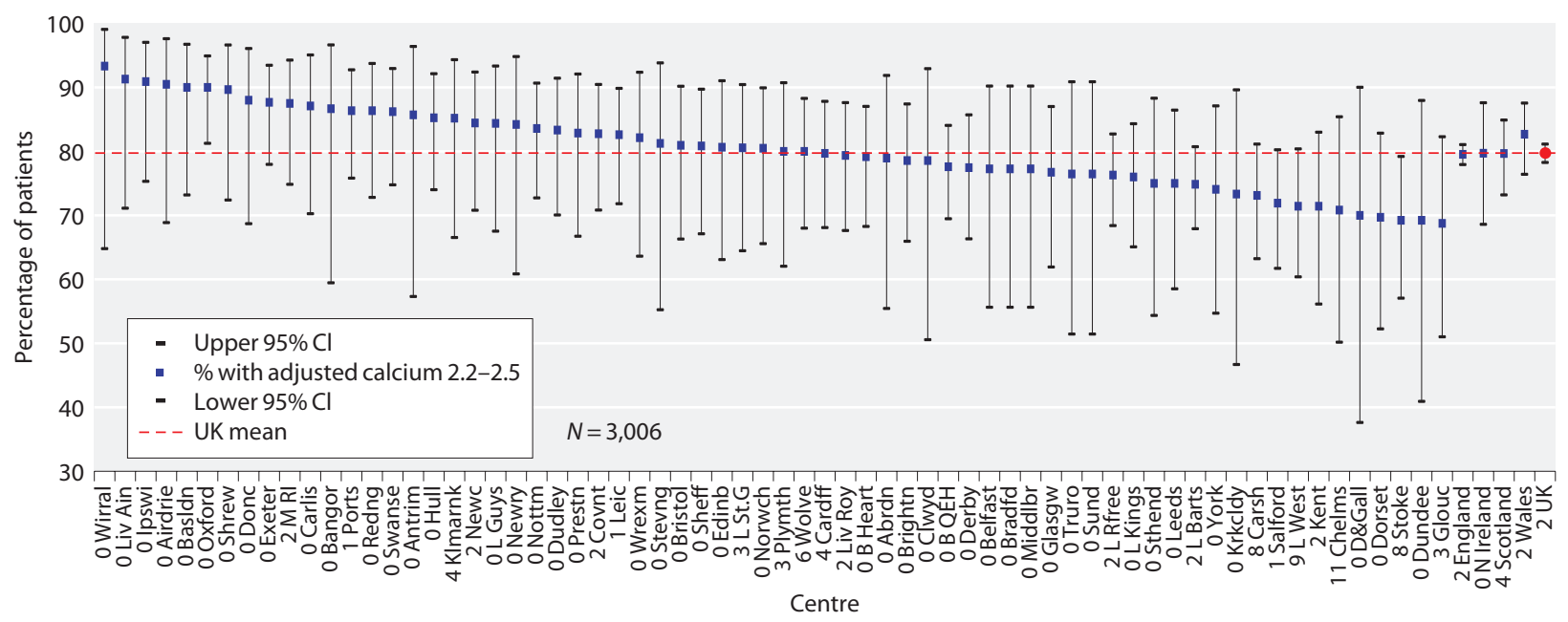

Fig. 8.19. Percentage of peritoneal dialysis patients with adjusted calcium within range (2.2-2.5 mmol/L) by centre in 2016 


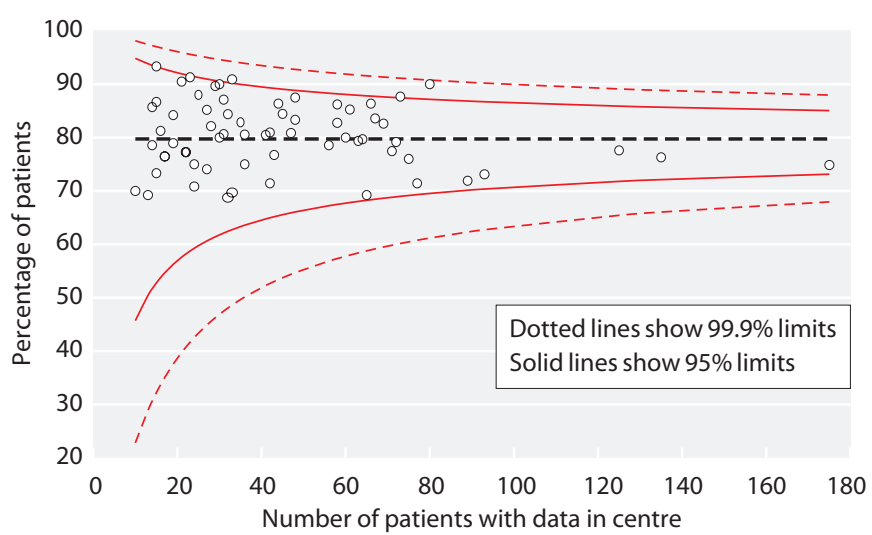

Fig. 8.20. Funnel plot of percentage of peritoneal dialysis patients with adjusted calcium within range $(2.2-2.5 \mathrm{mmol} / \mathrm{L})$ by centre in 2016
Longitudinal measures of serum adjusted calcium show stable attainment of national standards over the last decade (figure 8.21).

Phosphate

In 2016 the following Renal Association clinical practice guideline regarding phosphate management was applicable:

Guideline 3.2 CKD-MBD: Serum phosphate in dialysis patients

'We suggest that serum phosphate in dialysis patients, measured before a "short-gap" dialysis session in haemodialysis patients, should be maintained between 1.1 and $1.7 \mathrm{mmol} / \mathrm{L}(2 \mathrm{C})^{\prime}[2]$

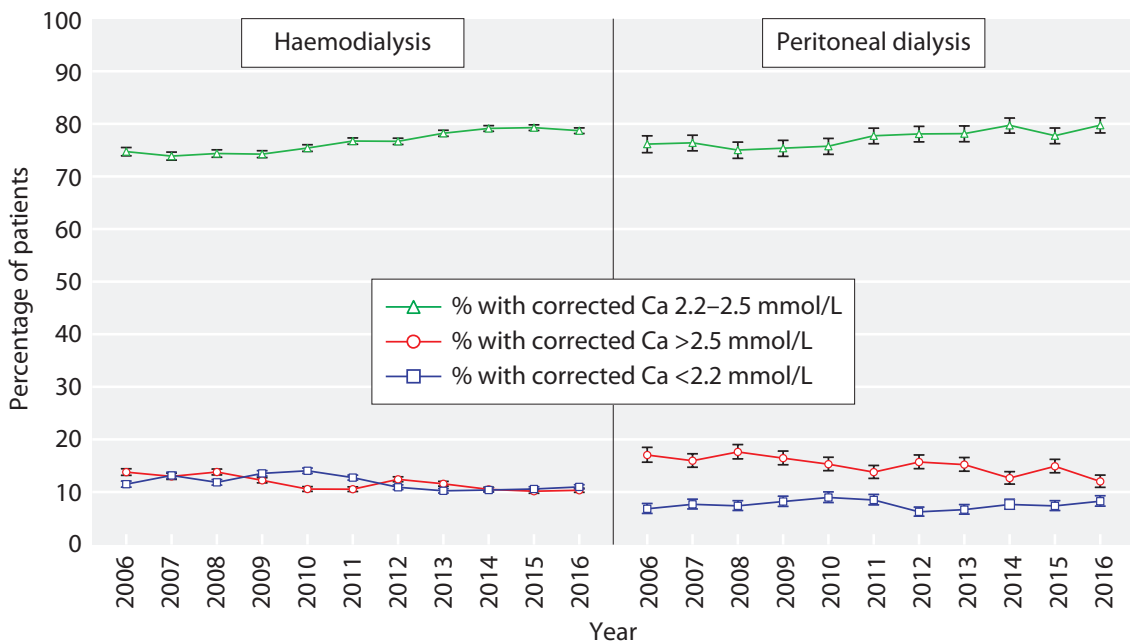

Fig. 8.21. Longitudinal change in percentage of patients with adjusted calcium $<2.2 \mathrm{mmol} / \mathrm{L}, 2.2-2.5 \mathrm{mmol} / \mathrm{L}$ and $>2.5 \mathrm{mmol} / \mathrm{L}$ by dialysis modality $2006-$ 2016

\section{Haemodialysis}

Table 8.19. Percentage of haemodialysis patients with serum phosphate within, below or above the target range of $1.1-1.7 \mathrm{mmol} / \mathrm{L}$, as specified in the RA guidelines, by centre in 2016

\begin{tabular}{|c|c|c|c|c|c|c|c|c|c|}
\hline Centre & $N$ & $\begin{array}{c}\% \text { phos } \\
1.1-1.7 \mathrm{mmol} / \mathrm{L}\end{array}$ & $\begin{array}{l}\text { Lower } \\
95 \% \text { CI }\end{array}$ & $\begin{array}{l}\text { Upper } \\
95 \% \text { CI }\end{array}$ & $\begin{array}{c}\% \text { phos } \\
<1.1 \mathrm{mmol} / \mathrm{L}\end{array}$ & $\begin{array}{c}\% \text { phos } \\
>1.7 \mathrm{mmol} / \mathrm{L}\end{array}$ & $\begin{array}{l}\text { Change in \% } \\
\text { within range } \\
\text { from } 2015\end{array}$ & $\begin{array}{l}95 \% \\
\text { LCL } \\
\text { change }\end{array}$ & $\begin{array}{l}95 \% \\
\text { UCL } \\
\text { change }\end{array}$ \\
\hline \multicolumn{10}{|l|}{ England } \\
\hline B Heart & 373 & 43.7 & 38.8 & 48.8 & 8.9 & 47.5 & -11.2 & -26.4 & 4.1 \\
\hline B QEH & 934 & 63.2 & 60.0 & 66.2 & 10.4 & 26.5 & 0.5 & -12.0 & 13.0 \\
\hline Basldn & 147 & 57.1 & 49.0 & 64.9 & 7.5 & 35.4 & 3.2 & -12.0 & 18.4 \\
\hline Bradfd & 226 & 56.6 & 50.1 & 63.0 & 16.4 & 27.0 & -1.0 & -15.5 & 13.6 \\
\hline Brightn & 418 & 51.0 & 46.2 & 55.7 & 10.3 & 38.8 & -5.4 & -20.0 & 9.1 \\
\hline Bristol & 470 & 47.9 & 43.4 & 52.4 & 12.3 & 39.8 & -12.7 & -27.4 & 2.0 \\
\hline Carlis & 88 & 55.7 & 45.2 & 65.7 & 11.4 & 33.0 & 2.4 & -14.9 & 19.6 \\
\hline Carsh & 771 & 59.0 & 55.5 & 62.4 & 11.0 & 30.0 & -1.0 & -14.1 & 12.2 \\
\hline Chelms & 118 & 62.7 & 53.7 & 71.0 & 6.8 & 30.5 & 10.5 & -4.4 & 25.4 \\
\hline Colchr & 92 & 68.5 & 58.3 & 77.1 & 10.9 & 20.7 & 1.5 & -13.2 & 16.2 \\
\hline Covnt & 345 & 55.1 & 49.8 & 60.3 & 6.7 & 38.3 & -2.3 & -16.5 & 11.9 \\
\hline
\end{tabular}


Table 8.19. Continued

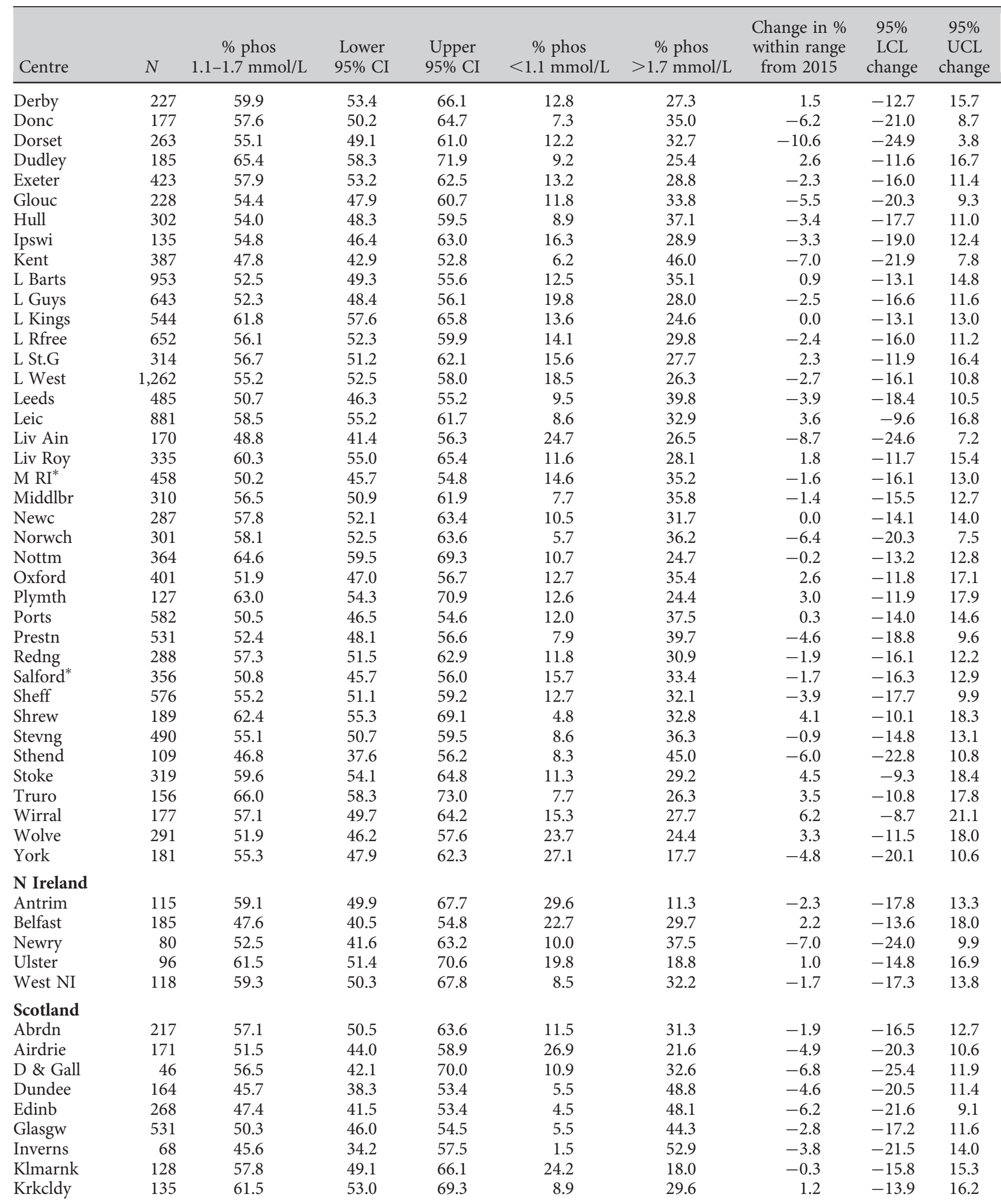


Table 8.19. Continued

\begin{tabular}{|c|c|c|c|c|c|c|c|c|c|}
\hline Centre & $N$ & $\begin{array}{c}\text { \% phos } \\
1.1-1.7 \mathrm{mmol} / \mathrm{L}\end{array}$ & $\begin{array}{l}\text { Lower } \\
95 \% \text { CI }\end{array}$ & $\begin{array}{l}\text { Upper } \\
95 \% \text { CI }\end{array}$ & $\begin{array}{c}\% \text { phos } \\
<1.1 \mathrm{mmol} / \mathrm{L}\end{array}$ & $\begin{array}{c}\% \text { phos } \\
>1.7 \mathrm{mmol} / \mathrm{L}\end{array}$ & $\begin{array}{c}\text { Change in } \% \\
\text { within range } \\
\text { from } 2015\end{array}$ & $\begin{array}{c}95 \% \\
\text { LCL } \\
\text { change }\end{array}$ & $\begin{array}{c}95 \% \\
\text { UCL } \\
\text { change }\end{array}$ \\
\hline \multicolumn{10}{|l|}{ Wales } \\
\hline Bangor & 68 & 51.5 & 39.7 & 63.1 & 22.1 & 26.5 & -13.9 & -30.9 & 3.1 \\
\hline Cardff & 480 & 53.5 & 49.1 & 58.0 & 7.1 & 39.4 & -6.2 & -20.4 & 7.9 \\
\hline Clwyd & 68 & 44.1 & 32.9 & 56.0 & 10.3 & 45.6 & -8.5 & -26.3 & 9.3 \\
\hline Swanse & 343 & 59.5 & 54.2 & 64.6 & 14.6 & 26.0 & -2.8 & -16.5 & 10.9 \\
\hline Wrexm & 113 & 59.3 & 50.0 & 68.0 & 30.1 & 10.6 & 5.8 & -10.3 & 21.8 \\
\hline England & 19,041 & 55.6 & 54.8 & 56.3 & 12.2 & 32.2 & -1.6 & -14.7 & 11.5 \\
\hline N Ireland & 594 & 55.1 & 51.0 & 59.0 & 19.0 & 25.9 & -1.1 & -14.9 & 12.7 \\
\hline Scotland & 1,728 & 51.8 & 49.4 & 54.1 & 9.8 & 38.4 & -3.2 & -17.0 & 10.6 \\
\hline Wales & 1,072 & 55.3 & 52.3 & 58.3 & 13.1 & 31.6 & -4.6 & -18.1 & 8.9 \\
\hline UK & 22,435 & 55.2 & 54.6 & 55.9 & 12.3 & 32.5 & -1.8 & -15.0 & 11.3 \\
\hline
\end{tabular}

Centres missing from the table were excluded from analysis due to low patient numbers or poor data completeness

*Salford and Manchester RI have been involved in the SPIRiT study - an RCT comparing low phosphate control (0.8-1.4 mmol/L) with high phosphate control $(1.8-2.4 \mathrm{mmol} / \mathrm{L})$; HD patients only were recruited

For those receiving $\mathrm{HD}, 55.2 \%$ of patients achieved a phosphate level between $1.1-1.7 \mathrm{mmol} / \mathrm{L}$, the guideline specified by the RA (as opposed to the audit measure), and for those on PD this was $60.3 \%$ (tables 8.19, 8.20).

There was inter-centre variation in the proportion of patients within the phosphate target range specified by the clinical guideline (figures 8.22-8.25, tables 8.19, 8.20).

Funnel plots for HD patients with phosphate within the target range $(1.1-1.7 \mathrm{mmol} / \mathrm{L})$, show two centres (Birmingham Queen Elizabeth, Nottingham) attaining this standard in a significantly high proportion of patients (being above the $99.9 \%$ upper confidence interval following correction for centre size). In addition, only one centre (Birmingham Heartlands) had achieved the serum phosphate control standard in a lower than expected proportion of patients (being below the lower 99.9\% confidence interval), (figure 8.23). Differences in outlier status can be seen when this guideline target measure is applied compared to the audit measure of phosphate $<1.7 \mathrm{mmol} / \mathrm{L}$, namely fewer centres were found to be outliers.

The funnel plot for PD patients indicated that the control of phosphate levels was similar in all centres. No significant outliers were identified (figure 8.25).

Longitudinal analysis had demonstrated stable performance against the clinical guideline recommendation

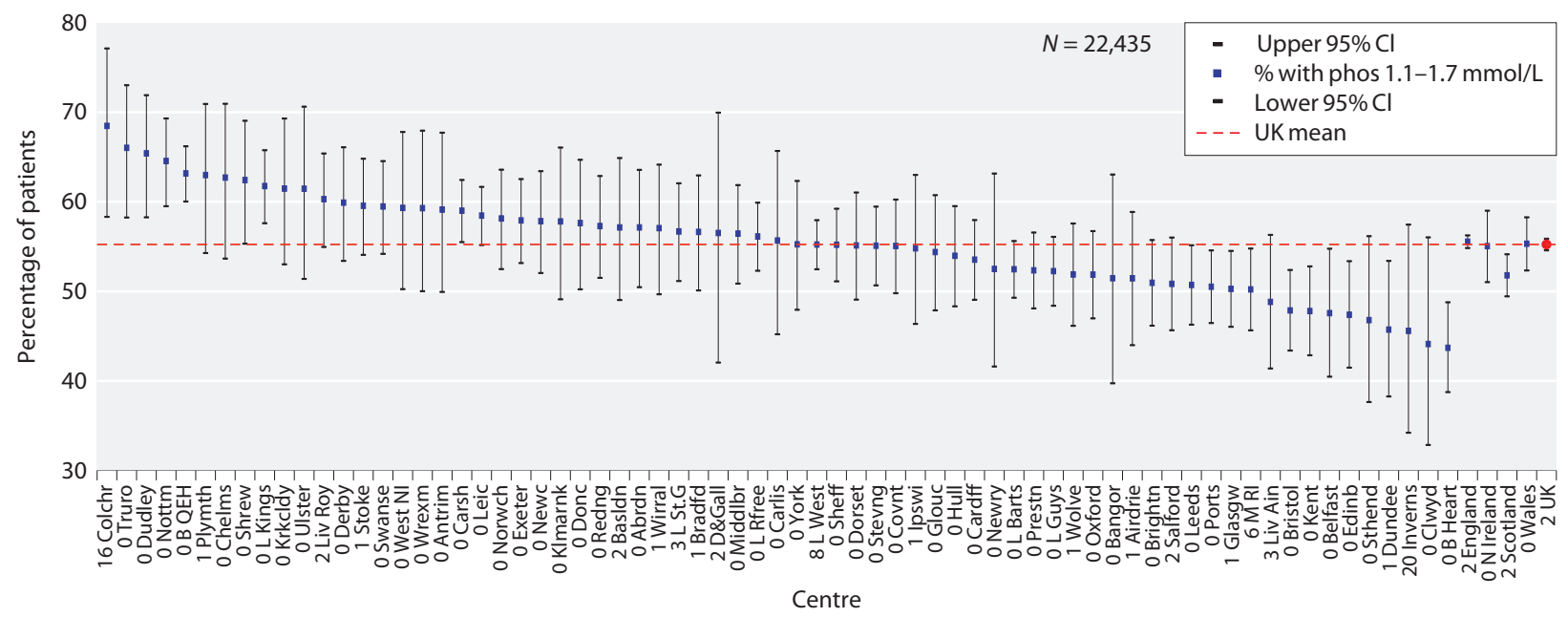

Fig. 8.22. Percentage of haemodialysis patients with phosphate within the range specified by the RA guideline (1.1-1.7 mmol/L) by centre in 2016 


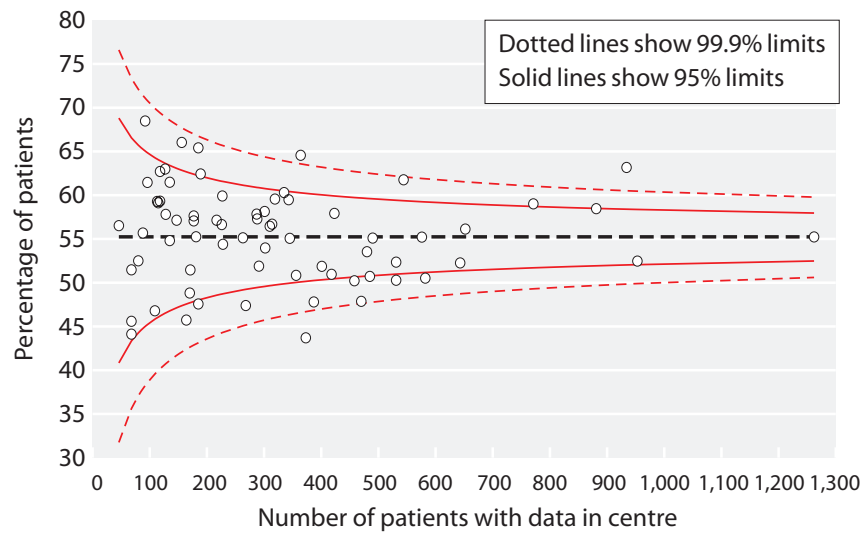

Fig. 8.23. Funnel plot of percentage of haemodialysis patients with phosphate within the range specified by the RA guideline $(1.1-1.7 \mathrm{mmol} / \mathrm{L})$ by centre in 2016 for those receiving $\mathrm{HD}$ and $\mathrm{PD}$ in recent years although there has been an increase in hyperphosphataemia in 2016 in both treatment modalities (figure 8.26).

\section{Parathyroid hormone}

At the beginning of 2016 the following RA guideline for PTH applied:

Guideline 4.2.1 CKD-MBD: Target range of serum $P T H$ in patients on dialysis

'We suggest that the target range for parathyroid hormone measured using an intact PTH assay should be between 2 and 9 times the upper limit of normal for the assay used (2C)' [2]

\section{Peritoneal dialysis}

Table 8.20. Percentage of peritoneal dialysis patients within, below and above the range specified in the RA guideline for phosphate $(1.1-1.7 \mathrm{mmol} / \mathrm{L})$ in 2016

\begin{tabular}{|c|c|c|c|c|c|c|c|c|c|}
\hline Centre & $N$ & $\begin{array}{c}\% \text { phos } \\
1.1-1.7 \mathrm{mmol} / \mathrm{L}\end{array}$ & $\begin{array}{l}\text { Lower } \\
95 \% \mathrm{CI}\end{array}$ & $\begin{array}{c}\text { Upper } \\
95 \% \mathrm{CI}\end{array}$ & $\begin{array}{c}\text { \% phos } \\
<1.1 \mathrm{mmol} / \mathrm{L}\end{array}$ & $\begin{array}{c}\% \text { phos } \\
>1.7 \mathrm{mmol} / \mathrm{L}\end{array}$ & $\begin{array}{c}\text { Change in \% } \\
\text { within range } \\
\text { from } 2015\end{array}$ & $\begin{array}{c}95 \% \\
\text { LCL } \\
\text { change }\end{array}$ & $\begin{array}{c}95 \% \\
\text { UCL } \\
\text { change }\end{array}$ \\
\hline \multicolumn{10}{|l|}{ England } \\
\hline B Heart & 72 & 44.4 & 33.5 & 56.0 & 2.8 & 52.8 & -5.6 & -24.8 & 13.7 \\
\hline B QEH & 125 & 61.6 & 52.8 & 69.7 & 5.6 & 32.8 & 5.4 & -6.9 & 17.7 \\
\hline Basldn & 30 & 63.3 & 45.1 & 78.4 & 6.7 & 30.0 & 4.1 & -21.2 & 29.4 \\
\hline Bradfd & 22 & 40.9 & 22.8 & 61.8 & 9.1 & 50.0 & 5.2 & -27.2 & 37.6 \\
\hline Brightn & 56 & 55.4 & 42.3 & 67.7 & 8.9 & 35.7 & -13.0 & -30.5 & 4.6 \\
\hline Bristol & 42 & 64.3 & 48.9 & 77.2 & 2.4 & 33.3 & 0.5 & -19.5 & 20.4 \\
\hline Carlis & 30 & 60.0 & 42.0 & 75.7 & 6.7 & 33.3 & -3.3 & -27.9 & 21.3 \\
\hline Carsh & 93 & 60.2 & 50.0 & 69.6 & 6.5 & 33.3 & 2.6 & -11.6 & 16.8 \\
\hline Chelms & 24 & 58.3 & 38.3 & 75.9 & 4.2 & 37.5 & 17.4 & -11.1 & 45.9 \\
\hline Covnt & 57 & 63.2 & 50.0 & 74.6 & 14.0 & 22.8 & -5.0 & -21.8 & 11.8 \\
\hline Derby & 71 & 74.7 & 63.3 & 83.4 & 9.9 & 15.5 & 7.5 & -7.3 & 22.3 \\
\hline Donc & 25 & 80.0 & 60.0 & 91.4 & 4.0 & 16.0 & -3.3 & -26.6 & 20.0 \\
\hline Dorset & 33 & 72.7 & 55.4 & 85.2 & 15.2 & 12.1 & -4.4 & -25.0 & 16.2 \\
\hline Dudley & 48 & 45.8 & 32.4 & 59.9 & 0.0 & 54.2 & -23.4 & -42.3 & -4.5 \\
\hline Exeter & 73 & 61.6 & 50.1 & 72.0 & 9.6 & 28.8 & -11.6 & -26.8 & 3.6 \\
\hline Glouc & 32 & 56.3 & 39.0 & 72.1 & 9.4 & 34.4 & -4.5 & -29.4 & 20.5 \\
\hline Hull & 61 & 52.5 & 40.0 & 64.6 & 11.5 & 36.1 & -6.9 & -24.3 & 10.5 \\
\hline Ipswi & 32 & 81.3 & 64.1 & 91.3 & 3.1 & 15.6 & 18.3 & -4.4 & 41.0 \\
\hline Kent & 42 & 64.3 & 48.9 & 77.2 & 16.7 & 19.1 & -2.4 & -21.6 & 16.8 \\
\hline L Barts & 175 & 58.9 & 51.4 & 65.9 & 5.1 & 36.0 & -1.5 & -11.7 & 8.7 \\
\hline L Guys & 32 & 56.3 & 39.0 & 72.1 & 6.3 & 37.5 & -9.3 & -33.7 & 15.1 \\
\hline L Kings & 75 & 66.7 & 55.3 & 76.4 & 8.0 & 25.3 & 7.9 & -7.3 & 23.1 \\
\hline L Rfree & 135 & 65.9 & 57.5 & 73.4 & 4.4 & 29.6 & 5.0 & -6.5 & 16.5 \\
\hline L St.G & 36 & 58.3 & 41.9 & 73.1 & 5.6 & 36.1 & -6.8 & -28.3 & 14.7 \\
\hline L West & 77 & 57.1 & 45.9 & 67.7 & 7.8 & 35.1 & -6.3 & -23.5 & 10.8 \\
\hline Leeds & 36 & 44.4 & 29.3 & 60.7 & 5.6 & 50.0 & -3.6 & -24.9 & 17.8 \\
\hline Leic & 69 & 76.8 & 65.4 & 85.3 & 2.9 & 20.3 & 17.9 & 3.8 & 31.9 \\
\hline Liv Ain & 23 & 43.5 & 25.2 & 63.7 & 8.7 & 47.8 & -15.8 & -43.2 & 11.7 \\
\hline
\end{tabular}


Table 8.20. Continued

\begin{tabular}{|c|c|c|c|c|c|c|c|c|c|}
\hline Centre & $N$ & $\begin{array}{c}\text { \% phos } \\
1.1-1.7 \mathrm{mmol} / \mathrm{L}\end{array}$ & $\begin{array}{l}\text { Lower } \\
95 \% \text { CI }\end{array}$ & $\begin{array}{l}\text { Upper } \\
95 \% \text { CI }\end{array}$ & $\begin{array}{c}\text { \% phos } \\
<1.1 \mathrm{mmol} / \mathrm{L}\end{array}$ & $\begin{array}{c}\% \text { phos } \\
>1.7 \mathrm{mmol} / \mathrm{L}\end{array}$ & $\begin{array}{c}\text { Change in \% } \\
\text { within range } \\
\text { from } 2015\end{array}$ & $\begin{array}{c}95 \% \\
\text { LCL } \\
\text { change }\end{array}$ & $\begin{array}{c}95 \% \\
\text { UCL } \\
\text { change }\end{array}$ \\
\hline Liv Roy & 63 & 69.8 & 57.5 & 79.9 & 14.3 & 15.9 & 15.7 & -1.1 & 32.6 \\
\hline M RI & 48 & 54.2 & 40.1 & 67.6 & 12.5 & 33.3 & 2.5 & -16.6 & 21.5 \\
\hline Middlbr & 22 & 63.6 & 42.3 & 80.7 & 0.0 & 36.4 & -7.8 & -38.8 & 23.3 \\
\hline Newc & 46 & 47.8 & 34.0 & 62.1 & 4.4 & 47.8 & -12.7 & -33.9 & 8.5 \\
\hline Norwch & 41 & 63.4 & 47.9 & 76.6 & 4.9 & 31.7 & 2.7 & -20.6 & 26.0 \\
\hline Nottm & 67 & 70.2 & 58.2 & 79.9 & 3.0 & 26.9 & -1.7 & -17.3 & 13.8 \\
\hline Oxford & 80 & 63.8 & 52.7 & 73.5 & 3.8 & 32.5 & 1.7 & -13.3 & 16.7 \\
\hline Plymth & 29 & 62.1 & 43.6 & 77.6 & 10.3 & 27.6 & -0.9 & -26.3 & 24.5 \\
\hline Ports & 64 & 48.4 & 36.5 & 60.5 & 4.7 & 46.9 & -6.0 & -23.8 & 11.9 \\
\hline Prestn & 35 & 48.6 & 32.7 & 64.7 & 8.6 & 42.9 & -16.7 & -38.0 & 4.5 \\
\hline Redng & 44 & 61.4 & 46.4 & 74.5 & 2.3 & 36.4 & -16.6 & -34.5 & 1.2 \\
\hline Salford & 89 & 52.8 & 42.5 & 62.9 & 3.4 & 43.8 & -4.5 & -19.4 & 10.4 \\
\hline Sheff & 47 & 68.1 & 53.6 & 79.8 & 0.0 & 31.9 & 2.0 & -16.2 & 20.2 \\
\hline Shrew & 29 & 75.9 & 57.3 & 88.0 & 0.0 & 24.1 & 9.2 & -14.4 & 32.8 \\
\hline Stevng & 16 & 62.5 & 37.7 & 82.1 & 12.5 & 25.0 & 16.4 & -19.7 & 52.4 \\
\hline Sthend & 24 & 66.7 & 46.1 & 82.4 & 8.3 & 25.0 & 0.0 & -30.4 & 30.4 \\
\hline Stoke & 70 & 41.4 & 30.5 & 53.2 & 11.4 & 47.1 & -24.8 & -40.9 & -8.6 \\
\hline Sund & 17 & 64.7 & 40.4 & 83.2 & 11.8 & 23.5 & 18.6 & -16.8 & 53.9 \\
\hline Truro & 17 & 58.8 & 35.2 & 79.0 & 5.9 & 35.3 & -4.3 & -36.2 & 27.6 \\
\hline Wirral & 14 & 42.9 & 20.7 & 68.4 & 7.1 & 50.0 & -4.2 & -39.3 & 30.9 \\
\hline Wolve & 59 & 64.4 & 51.5 & 75.5 & 5.1 & 30.5 & -2.8 & -19.4 & 13.9 \\
\hline York & 27 & 70.4 & 51.0 & 84.4 & 11.1 & 18.5 & 13.2 & -14.1 & 40.5 \\
\hline \multicolumn{10}{|l|}{ N Ireland } \\
\hline Antrim & 14 & 78.6 & 50.6 & 92.9 & 7.1 & 14.3 & 19.8 & -12.0 & 51.5 \\
\hline Belfast & 22 & 63.6 & 42.3 & 80.7 & 4.6 & 31.8 & 0.5 & -29.1 & 30.1 \\
\hline Newry & 19 & 63.2 & 40.3 & 81.3 & 5.3 & 31.6 & -20.2 & -47.9 & 7.5 \\
\hline \multicolumn{10}{|l|}{ Scotland } \\
\hline Abrdn & 19 & 47.4 & 26.8 & 68.9 & 10.5 & 42.1 & 4.5 & -26.3 & 35.4 \\
\hline Airdrie & 20 & 75.0 & 52.2 & 89.2 & 10.0 & 15.0 & & & \\
\hline D \& Gall & 10 & 70.0 & 37.6 & 90.0 & 0.0 & 30.0 & 30.0 & -11.6 & 71.6 \\
\hline Dundee & 13 & 53.9 & 28.2 & 77.6 & 0.0 & 46.2 & -2.4 & -38.8 & 34.0 \\
\hline Edinb & 28 & 53.6 & 35.4 & 70.8 & 0.0 & 46.4 & -11.1 & -40.4 & 18.1 \\
\hline Glasgw & 42 & 59.5 & 44.3 & 73.1 & 4.8 & 35.7 & -1.8 & -22.5 & 18.8 \\
\hline Klmarnk & 27 & 55.6 & 36.9 & 72.8 & 7.4 & 37.0 & 16.2 & -8.9 & 41.3 \\
\hline Krkcldy & 15 & 73.3 & 46.7 & 89.6 & 0.0 & 26.7 & 4.6 & -27.3 & 36.5 \\
\hline \multicolumn{10}{|l|}{ Wales } \\
\hline Bangor & 15 & 80.0 & 53.0 & 93.4 & 6.7 & 13.3 & 33.9 & 0.0 & 67.7 \\
\hline Cardff & 64 & 56.3 & 44.0 & 67.8 & 6.3 & 37.5 & -6.6 & -23.2 & 10.0 \\
\hline Clwyd & 14 & 50.0 & 26.0 & 74.0 & 21.4 & 28.6 & -11.5 & -48.8 & 25.7 \\
\hline Swanse & 58 & 55.2 & 42.3 & 67.4 & 5.2 & 39.7 & -3.0 & -21.3 & 15.3 \\
\hline Wrexm & 28 & 50.0 & 32.3 & 67.7 & 17.9 & 32.1 & -7.6 & -32.6 & 17.5 \\
\hline England & 2,574 & 60.3 & 58.4 & 62.2 & 6.6 & 33.1 & -1.6 & -4.2 & 1.1 \\
\hline $\mathrm{N}$ Ireland & 69 & 68.1 & 56.3 & 78.0 & 4.4 & 27.5 & -2.9 & -18.2 & 12.5 \\
\hline Scotland & 177 & 59.9 & 52.5 & 66.9 & 4.5 & 35.6 & 7.1 & -3.2 & 17.4 \\
\hline Wales & 179 & 56.4 & 49.1 & 63.5 & 8.9 & 34.6 & -2.8 & -13.0 & 7.3 \\
\hline UK & 2,999 & 60.3 & 58.5 & 62.0 & 6.6 & 33.2 & -1.2 & -3.6 & 1.3 \\
\hline
\end{tabular}

Centres missing from the table were excluded from analysis due to low patient numbers or poor data completeness Blank cells indicate no data for 2015 


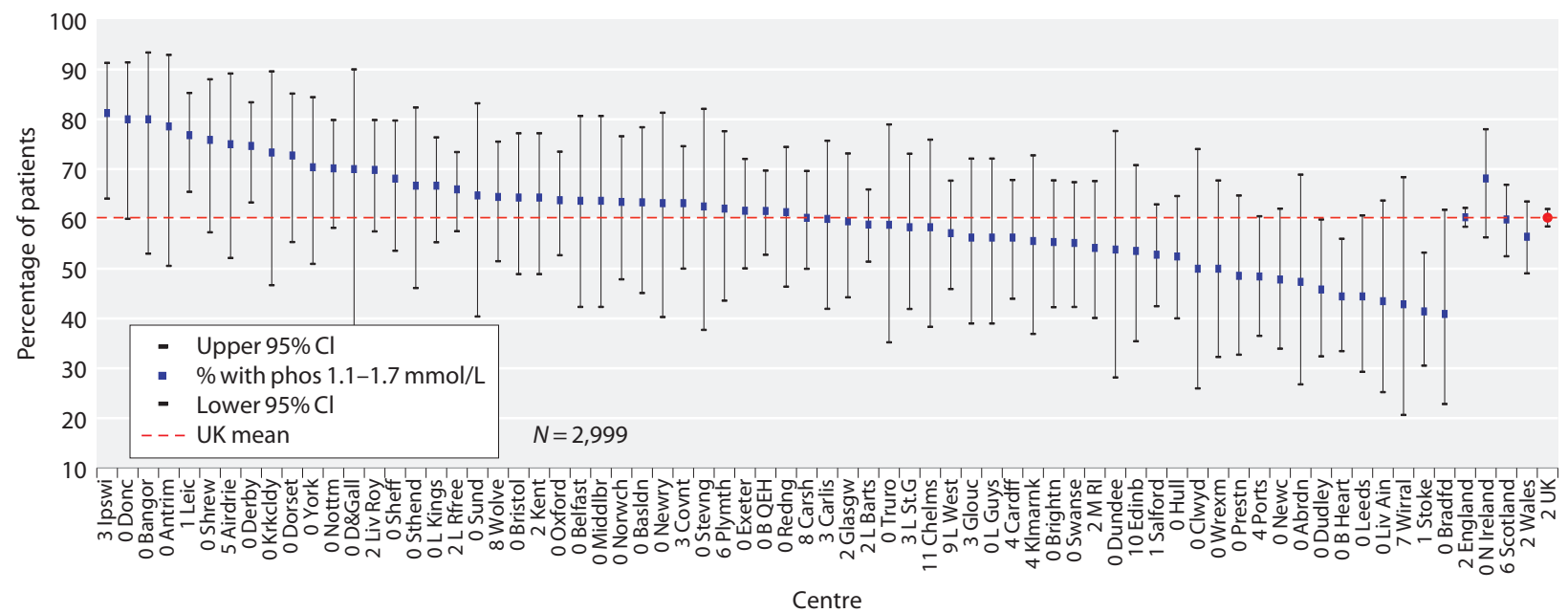

Fig. 8.24. Percentage of peritoneal dialysis patients with phosphate within the range specified by the RA guideline (1.1-1.7 mmol/L) by centre in 2016

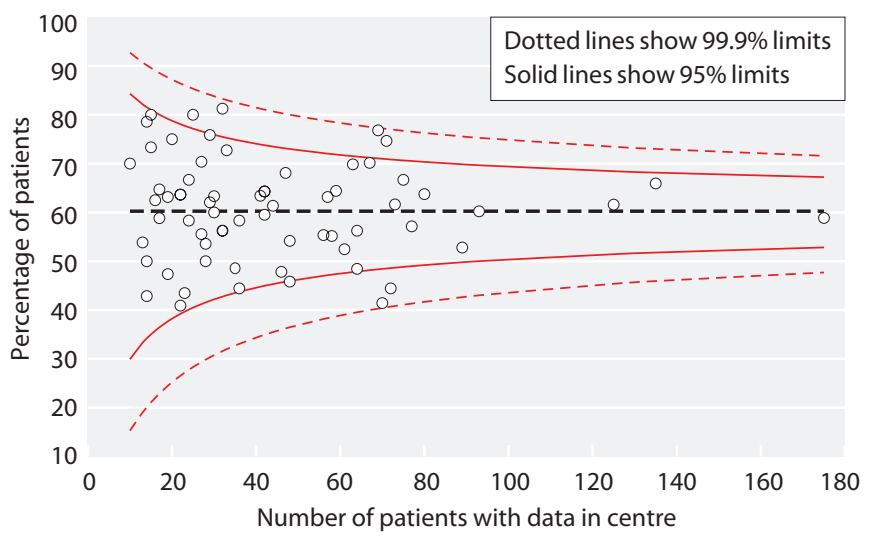

Fig. 8.25. Funnel plot of percentage of peritoneal dialysis patients with phosphate within the range specified by the RA guideline $(1.1-1.7 \mathrm{mmol} / \mathrm{L})$ by centre in 2016
PTH results from 18,420 HD patients and 2,404 PD patients from England, Northern Ireland and Wales were available for analysis from 2016. The data were 87.1\% complete for $\mathrm{HD}$ patients and $83.7 \%$ for $\mathrm{PD}$ patients overall, although there was inter-centre variation (tables 8.21, 8.23). For the analyses, Birmingham Queen Elizabeth, Cambridge, Salford and Sheffield were excluded due to poor data completeness.

Median PTH amongst HD patients was $32 \mathrm{pmol} / \mathrm{L}$ (IQR 16-58 pmol/L) and amongst $\mathrm{PD}$ patients was $31 \mathrm{pmol} / \mathrm{L}$ (IQR $18-52 \mathrm{pmol} / \mathrm{L}$ ) for the three countries.

Of HD patients, $58.3 \%$ (95\% CI 57.6-59.0\%) and of PD patients, 65.7\% (95\% CI 63.8-67.6\%) achieved a $\mathrm{PTH}$ between 16-72 pmol/L (tables 8.22, 8.24, figures 8.27, 8.29).

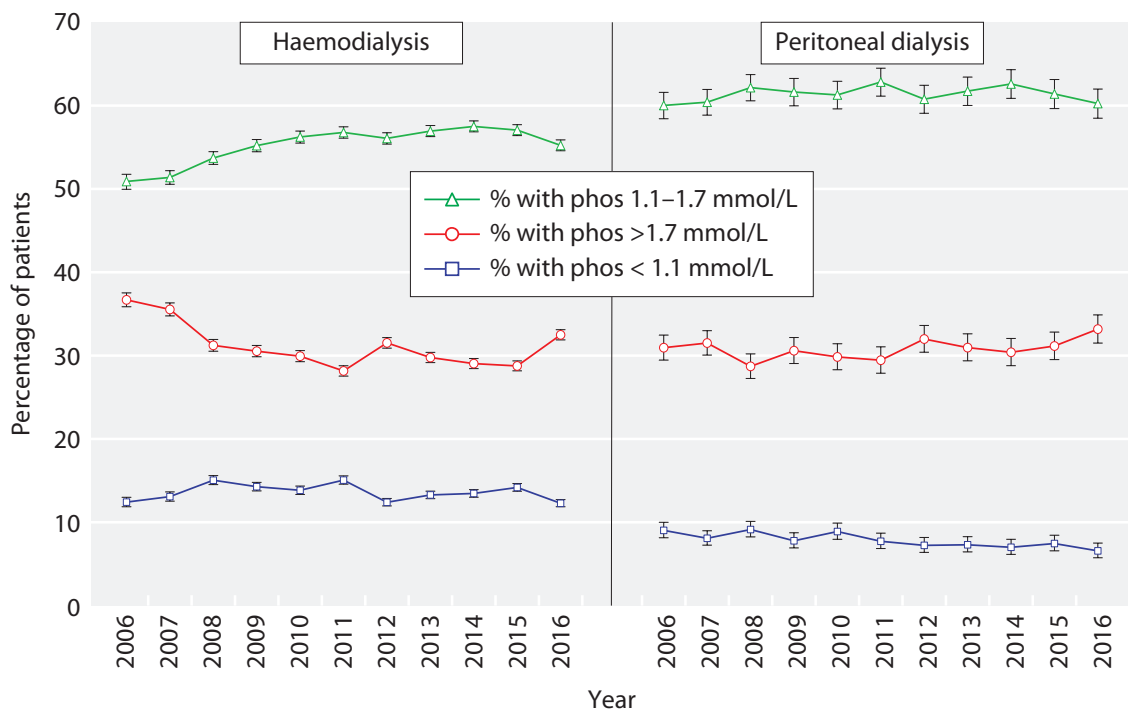

Fig. 8.26. Longitudinal change in percentage of patients with phosphate below, within and above the RA guideline by dialysis modality 2006-2016 
Table 8.21. Summary statistics for PTH in haemodialysis patients in 2016

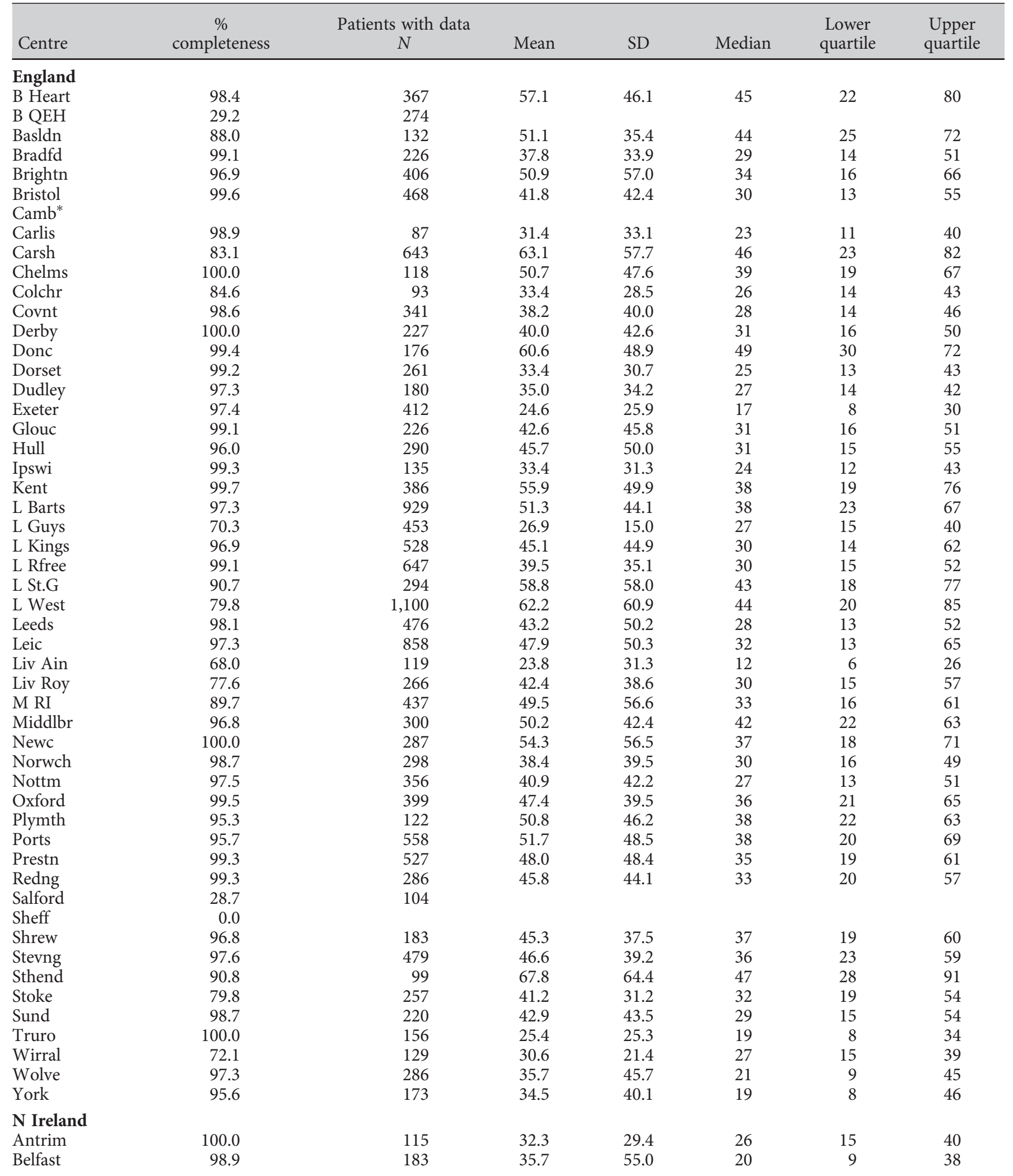


Table 8.21. Continued

\begin{tabular}{|c|c|c|c|c|c|c|c|}
\hline Centre & $\begin{array}{c}\% \\
\text { completeness }\end{array}$ & $\begin{array}{c}\text { Patients with data } \\
\qquad N\end{array}$ & Mean & $\mathrm{SD}$ & Median & $\begin{array}{l}\text { Lower } \\
\text { quartile }\end{array}$ & $\begin{array}{l}\text { Upper } \\
\text { quartile }\end{array}$ \\
\hline Newry & 100.0 & 80 & 28.6 & 24.8 & 23 & 15 & 36 \\
\hline West NI & 99.2 & 117 & 28.4 & 19.3 & 24 & 15 & 37 \\
\hline \multicolumn{8}{|l|}{ Wales } \\
\hline Bangor & 98.5 & 67 & 29.6 & 37.3 & 18 & 10 & 35 \\
\hline Swanse & 99.7 & 342 & 39.9 & 39.6 & 30 & 16 & 52 \\
\hline Wrexm & 98.2 & 111 & 25.4 & 31.7 & 12 & 5 & 34 \\
\hline England & 86.1 & 16,775 & 46.3 & 46.5 & 33 & 16 & 60 \\
\hline N Ireland & 99.3 & 590 & 31.2 & 36.9 & 23 & 13 & 38 \\
\hline Wales & 98.3 & 1,055 & 41.2 & 41.2 & 31 & 14 & 54 \\
\hline
\end{tabular}

Blank cells: centres excluded from analysis due to low patient numbers or poor data completeness

* Cambridge renal centre was unable to submit PTH data for 2016

Table 8.22. Percentage of haemodialysis patients within, below and above the range for PTH (16-72 pmol/L) in 2016

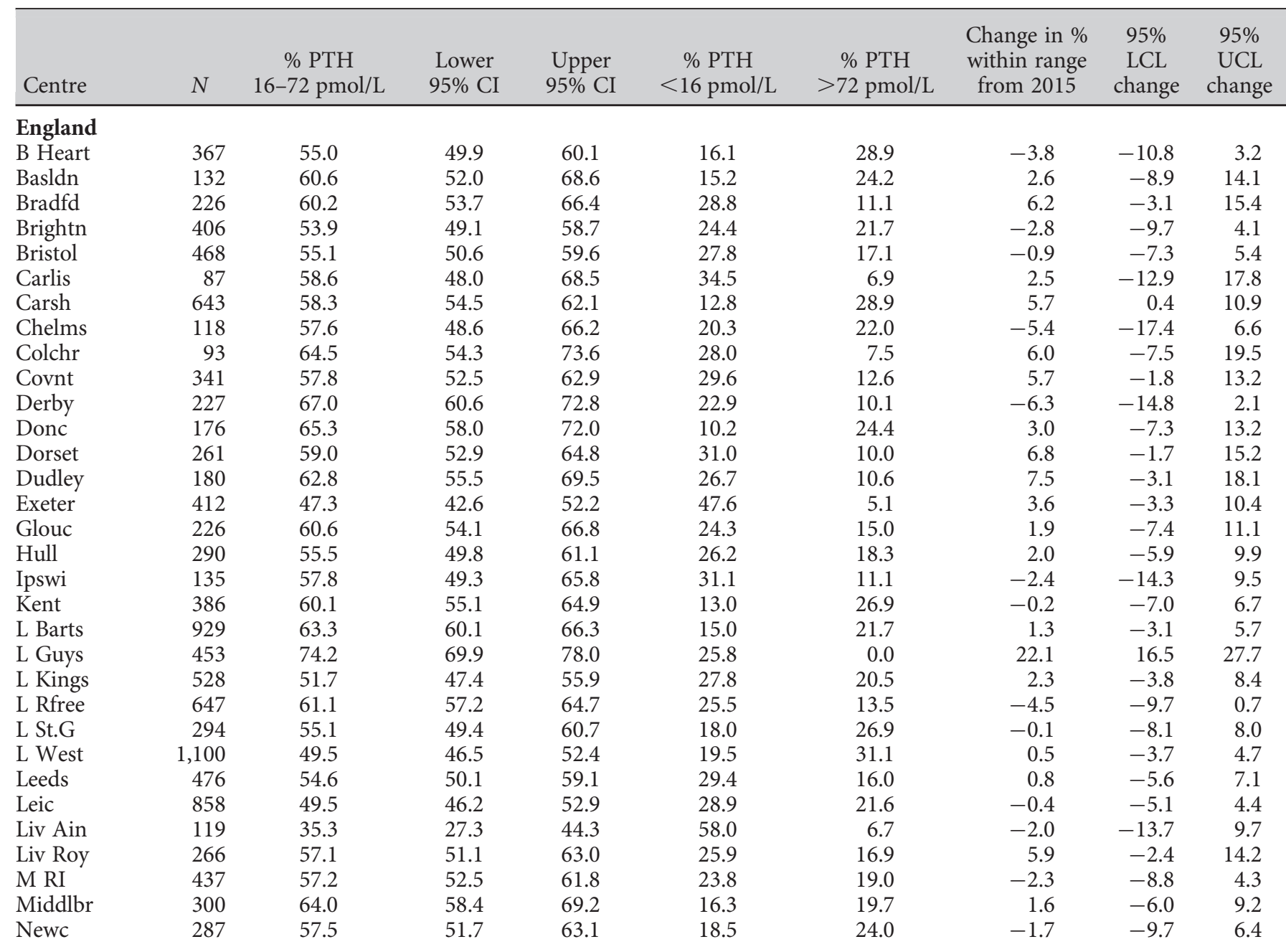


Table 8.22. Continued

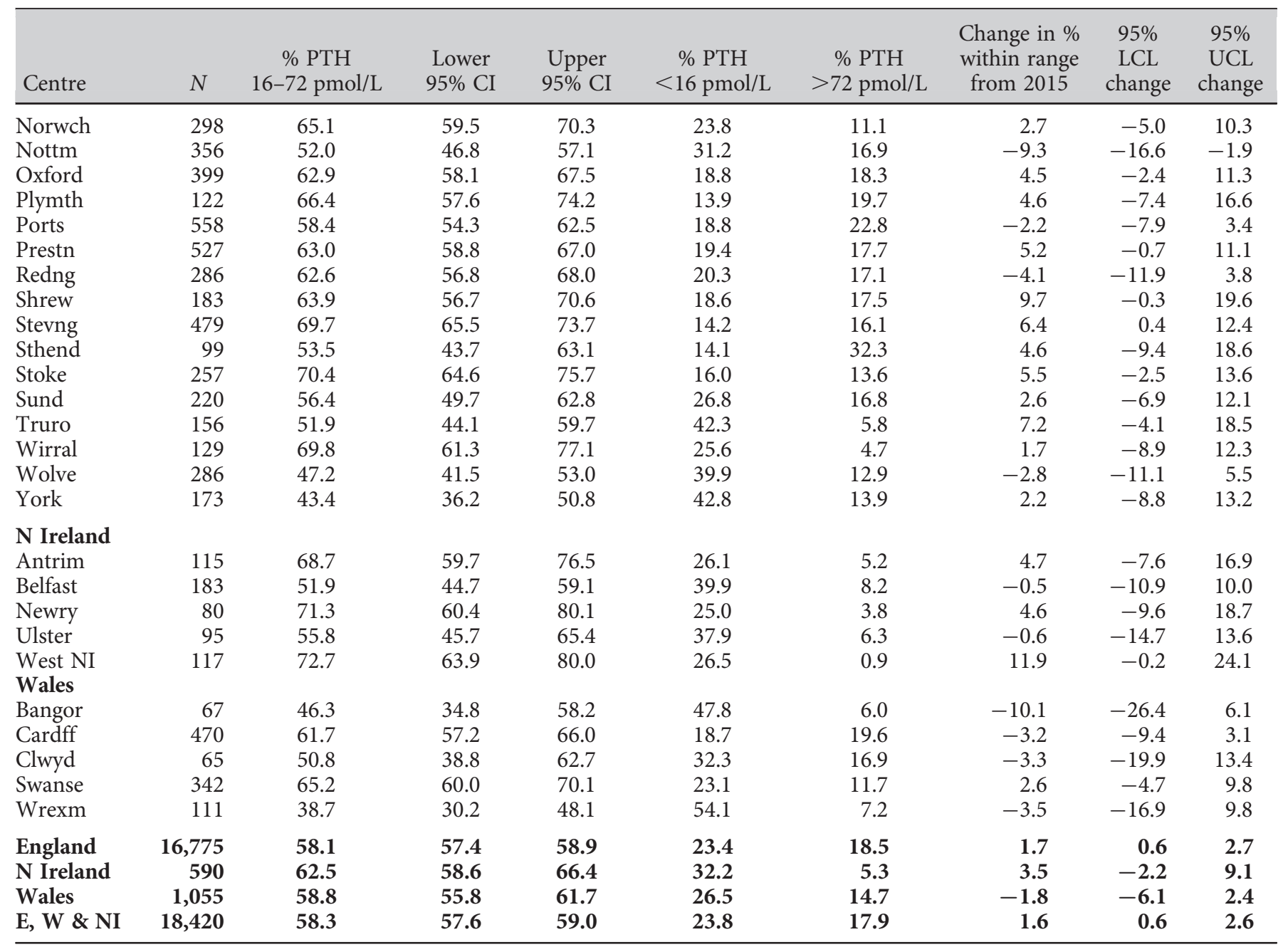

Centres missing from the table were excluded from analysis due to low patient numbers or poor data completeness

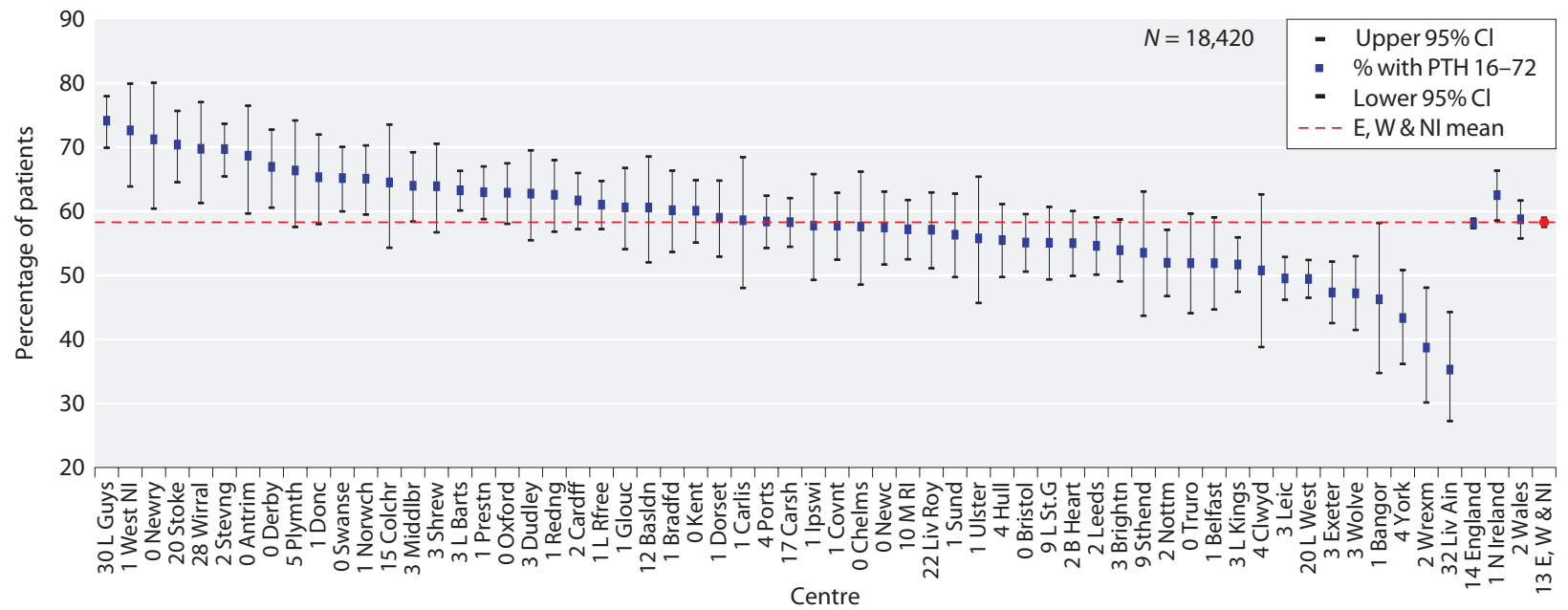

Fig. 8.27. Percentage of haemodialysis patients with PTH within range (16-72 pmol/L) by centre in 2016 


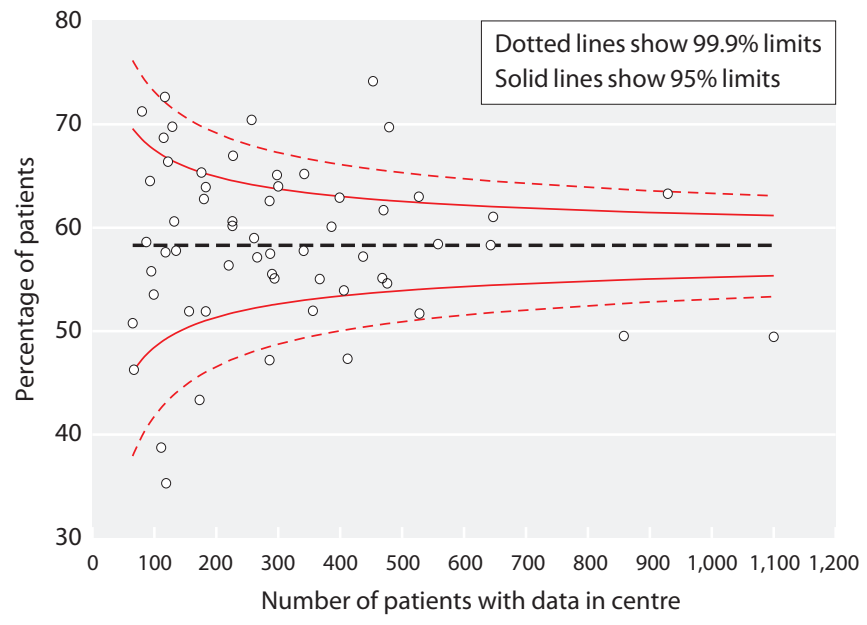

Fig. 8.28. Funnel plot of percentage of haemodialysis patients with PTH within range (16-72 pmol/L) by centre in 2016
In 2016, the proportion of HD patients with a PTH above the upper limit of the range $(>72 \mathrm{pmol} / \mathrm{L})$ was $17.9 \%$ and the proportion below the lower limit of the range $(<16 \mathrm{pmol} / \mathrm{L})$ was $23.8 \%$.

The proportion of PD patients with PTH above the upper limit $(>72 \mathrm{pmol} / \mathrm{L})$ of the range was $13.4 \%$ and the proportion below the lower limit of the range $(<16 \mathrm{pmol} / \mathrm{L}$ ) was $20.9 \%$ (tables $8.22,8.24)$.

There was significant variation by centre following unadjusted analyses for the proportion of patients below, within and above the range specified by the clinical performance measures. The funnel plot (figure 8.28) for HD patients showed above average achievement of the target range in London Guys, Stevenage, Stoke and West NI and below average achievement for Exeter, Leicester, Liverpool Aintree, London West,

Peritoneal dialysis

Table 8.23. Summary statistics for PTH in peritoneal dialysis patients in 2016

\begin{tabular}{|c|c|c|c|c|c|c|c|}
\hline Centre & $\begin{array}{c}\% \\
\text { completeness }\end{array}$ & $\begin{array}{l}\text { Patients with } \\
\text { data } N\end{array}$ & Mean & SD & Median & $\begin{array}{l}\text { Lower } \\
\text { quartile }\end{array}$ & $\begin{array}{l}\text { Upp } \\
\text { quart }\end{array}$ \\
\hline \multicolumn{8}{|l|}{ England } \\
\hline B Heart & 94.4 & 68 & 58.5 & 36.2 & 61 & 31 & 75 \\
\hline B QEH & 0.0 & 0 & & & & & \\
\hline Basldn & 100.0 & 30 & 41.7 & 26.4 & 37 & 22 & 58 \\
\hline Bradfd & 95.5 & 21 & 53.8 & 42.6 & 39 & 18 & 79 \\
\hline Brightn & 92.9 & 52 & 51.2 & 70.6 & 31 & 17 & 52 \\
\hline Bristol & 100.0 & 42 & 30.0 & 24.5 & 28 & 15 & 34 \\
\hline \multicolumn{8}{|l|}{$\mathrm{Camb}^{\mathrm{a}}$} \\
\hline Carlis & 100.0 & 31 & 35.5 & 23.4 & 34 & 17 & 43 \\
\hline Carsh & 79.2 & 80 & 68.0 & 44.5 & 58 & 35 & 89 \\
\hline Chelms & 85.2 & 23 & 55.8 & 55.7 & 33 & 20 & 91 \\
\hline \multicolumn{8}{|l|}{ Colchr ${ }^{\mathrm{b}}$} \\
\hline Covnt & 93.2 & 55 & 28.8 & 31.8 & 22 & 11 & 37 \\
\hline Derby & 97.2 & 69 & 32.6 & 23.2 & 27 & 19 & 38 \\
\hline Donc & 100.0 & 25 & 34.1 & 18.4 & 32 & 23 & 38 \\
\hline Dorset & 97.0 & 32 & 30.2 & 31.2 & 20 & 11 & 37 \\
\hline Dudley & 81.3 & 39 & 40.1 & 32.1 & 32 & 15 & 48 \\
\hline Exeter & 100.0 & 73 & 27.7 & 22.4 & 22 & 12 & 38 \\
\hline Glouc & 72.7 & 24 & 29.8 & 16.8 & 26 & 17 & 38 \\
\hline Hull & 91.8 & 56 & 27.2 & 18.2 & 24 & 13 & 37 \\
\hline Ipswi & 97.0 & 32 & 22.9 & 16.1 & 23 & 15 & 27 \\
\hline Kent & 97.7 & 42 & 36.7 & 35.2 & 29 & 19 & 48 \\
\hline L Barts & 91.6 & 164 & 43.8 & 33.7 & 37 & 21 & 56 \\
\hline L Guys & 84.4 & 27 & 29.5 & 12.4 & 29 & 18 & 40 \\
\hline L Kings & 88.0 & 66 & 61.4 & 52.2 & 42 & 24 & 92 \\
\hline L Rfree & 95.7 & 132 & 34.7 & 24.2 & 31 & 19 & 44 \\
\hline L St.G & 94.6 & 35 & 36.9 & 32.3 & 24 & 18 & 38 \\
\hline L West & 84.7 & 72 & 45.7 & 38.1 & 36 & 26 & 56 \\
\hline Leeds & 100.0 & 36 & 43.2 & 35.8 & 36 & 15 & 68 \\
\hline Leic & 92.9 & 65 & 39.0 & 39.2 & 26 & 13 & 49 \\
\hline Liv Ain & 95.7 & 22 & 20.8 & 18.9 & 16 & 10 & 28 \\
\hline Liv Roy & 98.4 & 63 & 21.2 & 13.6 & 20 & 11 & 30 \\
\hline M RI & 95.9 & 47 & 49.5 & 41.3 & 41 & 18 & 60 \\
\hline Middlbr & 68.2 & 15 & 55.3 & 40.3 & 52 & 27 & 71 \\
\hline
\end{tabular}


Table 8.23. Continued

\begin{tabular}{|c|c|c|c|c|c|c|c|}
\hline Centre & $\begin{array}{c}\% \\
\text { completeness }\end{array}$ & $\begin{array}{c}\text { Patients with } \\
\text { data } N\end{array}$ & Mean & SD & Median & $\begin{array}{l}\text { Lower } \\
\text { quartile }\end{array}$ & $\begin{array}{l}\text { Upper } \\
\text { quartile }\end{array}$ \\
\hline Newc & 91.3 & 42 & 36.4 & 30.3 & 26 & 12 & 60 \\
\hline Norwch & 75.6 & 31 & 45.5 & 30.7 & 44 & 27 & 57 \\
\hline Nottm & 98.5 & 66 & 36.5 & 32.4 & 28 & 17 & 46 \\
\hline Oxford & 97.5 & 78 & 35.7 & 25.8 & 32 & 15 & 43 \\
\hline Plymth & 87.1 & 27 & 30.3 & 20.0 & 28 & 17 & 37 \\
\hline Ports & 85.1 & 57 & 47.7 & 35.2 & 36 & 23 & 59 \\
\hline Prestn & 97.1 & 34 & 33.4 & 24.2 & 27 & 20 & 37 \\
\hline Redng & 95.5 & 42 & 39.7 & 24.6 & 32 & 23 & 65 \\
\hline Salford & 0.0 & 0 & & & & & \\
\hline Sheff & 0.0 & 0 & & & & & \\
\hline Shrew & 100.0 & 29 & 45.6 & 33.1 & 36 & 24 & 57 \\
\hline Stevng & 87.5 & 14 & 50.2 & 22.4 & 50 & 34 & 66 \\
\hline Sthend & 70.8 & 17 & 41.1 & 28.4 & 36 & 23 & 54 \\
\hline Stoke & 94.4 & 67 & 50.6 & 36.0 & 43 & 23 & 70 \\
\hline Sund & 100.0 & 17 & 26.0 & 15.3 & 26 & 14 & 39 \\
\hline Truro & 88.2 & 15 & 35.2 & 32.7 & 29 & 13 & 34 \\
\hline Wirral & 86.7 & 13 & 32.2 & 35.1 & 23 & 14 & 32 \\
\hline Wolve & 89.1 & 57 & 44.0 & 43.5 & 33 & 21 & 54 \\
\hline York & 92.6 & 25 & 38.4 & 34.8 & 30 & 17 & 49 \\
\hline \multicolumn{8}{|l|}{ N Ireland } \\
\hline Antrim & 100.0 & 14 & 24.3 & 19.6 & 22 & 7 & 40 \\
\hline Belfast & 95.5 & 21 & 29.1 & 18.8 & 25 & 19 & 40 \\
\hline Newry & 100.0 & 19 & 24.1 & 12.8 & 26 & 10 & 34 \\
\hline Ulster & 100.0 & 5 & & & & & \\
\hline West NI & 100.0 & 9 & & & & & \\
\hline \multicolumn{8}{|l|}{ Wales } \\
\hline Bangor & 100.0 & 15 & 34.6 & 26.6 & 30 & 15 & 54 \\
\hline Cardff & 80.6 & 54 & 55.7 & 41.4 & 43 & 31 & 75 \\
\hline Clwyd & 92.9 & 13 & 50.8 & 41.9 & 41 & 22 & 62 \\
\hline Swanse & 98.3 & 57 & 38.1 & 36.9 & 26 & 17 & 45 \\
\hline Wrexm & 100.0 & 28 & 33.1 & 25.6 & 25 & 15 & 37 \\
\hline England & 82.7 & 2,169 & 40.4 & 35.1 & 31 & 18 & 52 \\
\hline $\mathrm{N}$ Ireland & 98.6 & 68 & 25.2 & 16.9 & 24 & 11 & 34 \\
\hline Wales & 91.8 & 167 & 43.6 & 37.3 & 32 & 19 & 59 \\
\hline E, W \& NI & 83.7 & 2,404 & 40.2 & 35.0 & 31 & 18 & 52 \\
\hline
\end{tabular}

Blank cells: centres excluded from analysis due to small numbers or poor data completeness

${ }^{a}$ Cambridge renal centre was unable to submit PTH data for 2016

${ }^{\mathrm{b}}$ Colchester - no PD patients

Table 8.24. Percentage of peritoneal dialysis patients within, below and above the range for PTH (16-72 pmol/L) in 2016

\begin{tabular}{|c|c|c|c|c|c|c|c|c|c|}
\hline Centre & $N$ & $\begin{array}{c}\% \text { PTH } \\
16-72 \mathrm{pmol} / \mathrm{L}\end{array}$ & $\begin{array}{l}\text { Lower } \\
95 \% \text { CI }\end{array}$ & $\begin{array}{l}\text { Upper } \\
95 \% \text { CI }\end{array}$ & $\begin{array}{c}\% \mathrm{PTH} \\
<16 \mathrm{pmol} / \mathrm{L}\end{array}$ & $\begin{array}{c}\% \mathrm{PTH} \\
>72 \mathrm{pmol} / \mathrm{L}\end{array}$ & $\begin{array}{l}\text { Change in \% } \\
\text { within range } \\
\text { from } 2015\end{array}$ & $\begin{array}{c}95 \% \\
\text { LCL } \\
\text { change }\end{array}$ & $\begin{array}{c}95 \% \\
\text { UCL } \\
\text { change }\end{array}$ \\
\hline \multicolumn{10}{|l|}{ England } \\
\hline B Heart & 68 & 60.3 & 48.3 & 71.2 & 10.3 & 29.4 & 8.9 & -10.9 & 28.8 \\
\hline Basldn & 30 & 76.7 & 58.5 & 88.5 & 13.3 & 10.0 & 2.6 & -19.8 & 25.0 \\
\hline Bradfd & 21 & 52.4 & 31.8 & 72.2 & 19.1 & 28.6 & -32.2 & -61.2 & -3.2 \\
\hline Brightn & 52 & 63.5 & 49.7 & 75.3 & 23.1 & 13.5 & 5.8 & -12.3 & 24.0 \\
\hline Bristol & 42 & 69.1 & 53.7 & 81.1 & 26.2 & 4.8 & 3.1 & -16.7 & 22.9 \\
\hline Carlis & 31 & 77.4 & 59.6 & 88.8 & 16.1 & 6.5 & 10.8 & -12.3 & 33.8 \\
\hline Carsh & 80 & 58.8 & 47.7 & 69.0 & 6.3 & 35.0 & 4.6 & -10.5 & 19.7 \\
\hline Chelms & 23 & 52.2 & 32.5 & 71.2 & 21.7 & 26.1 & -9.7 & -38.9 & 19.4 \\
\hline Covnt & 55 & 52.7 & 39.7 & 65.4 & 40.0 & 7.3 & 5.1 & -13.0 & 23.2 \\
\hline
\end{tabular}


Table 8.24. Continued

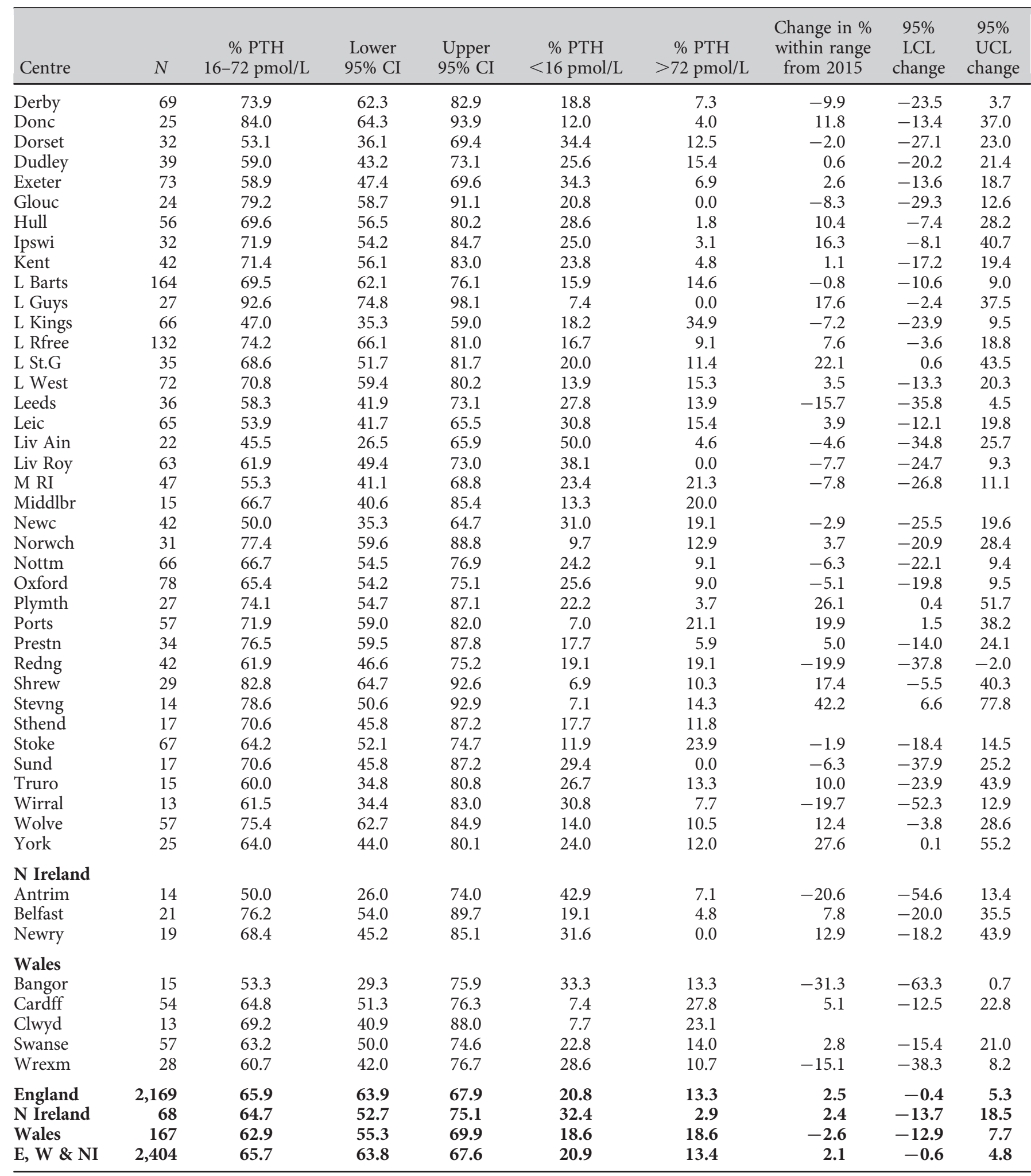

Centres missing from the table were excluded from analysis due to low patient numbers or poor data completeness

Blank cells indicate no data for 2015 


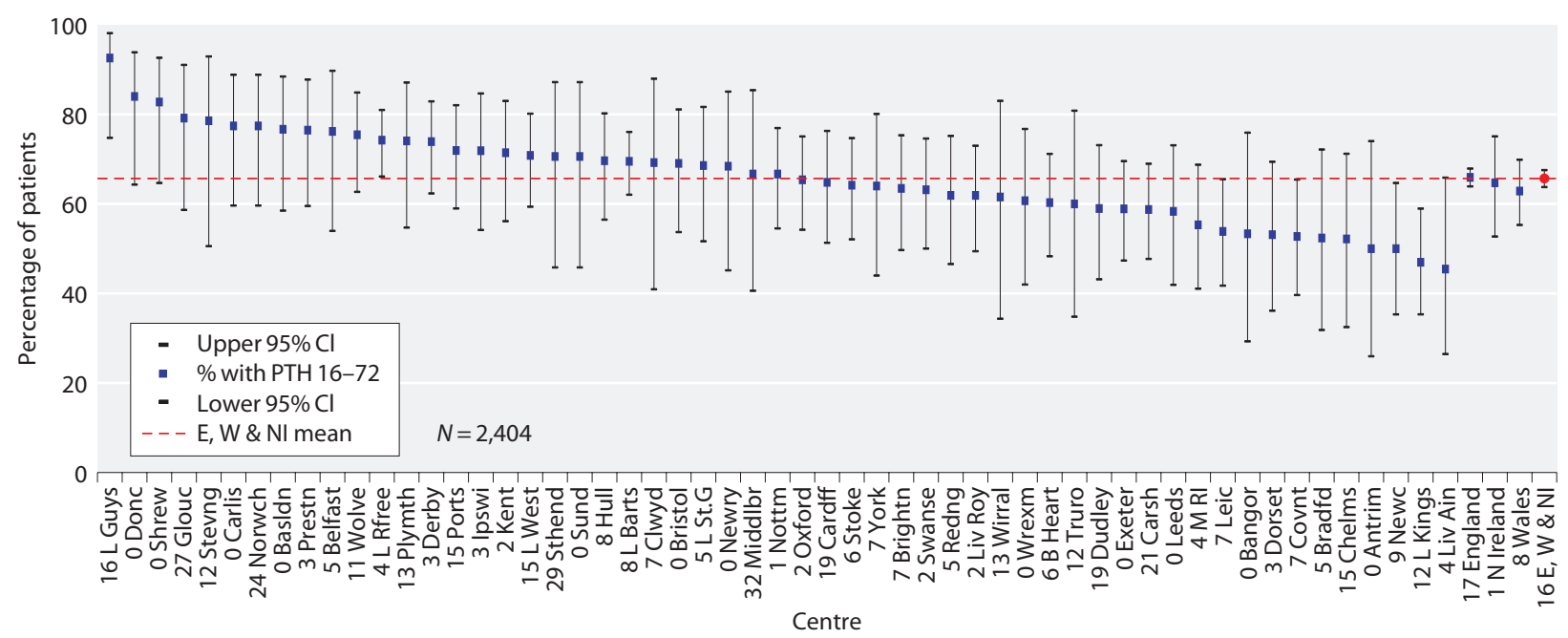

Fig. 8.29. Percentage of peritoneal dialysis patients with PTH within range (16-72 pmol/L) by centre in 2016

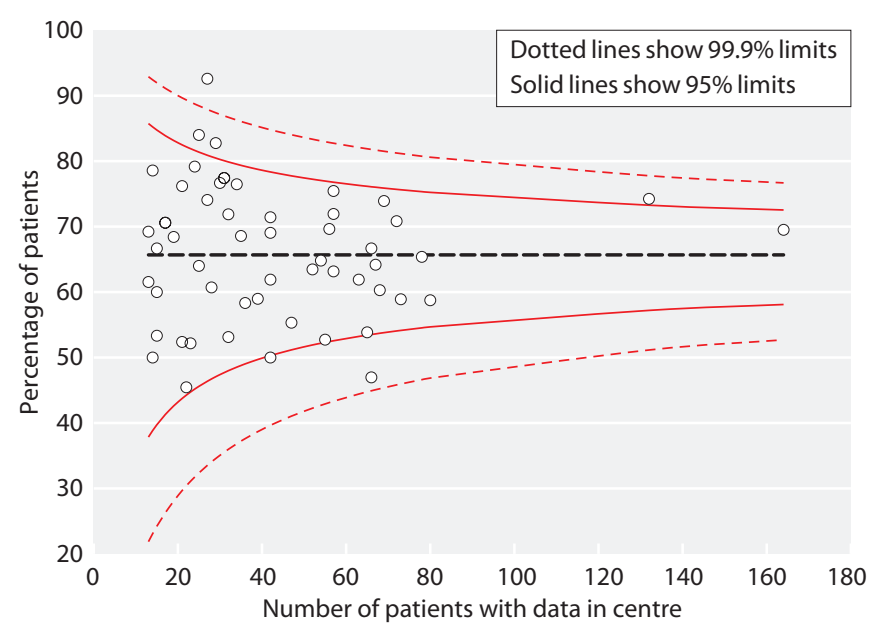

Fig. 8.30. Funnel plot of percentage of peritoneal dialysis patients with PTH within range $(16-72 \mathrm{pmol} / \mathrm{L})$ by centre in 2016
Wolverhampton, Wrexham and York. For PD patients (figure 8.30) London Guys was above average achievement of the target range and there were no outliers below the $99.9 \%$ confidence interval for the target.

Longitudinal analysis of PTH control measures at the level of the three countries noted sustained reduction in the proportion of patients with low PTH levels $(<16 \mathrm{pmol} / \mathrm{L})$ in $\mathrm{HD}$ and PD patients. Similarly, there has been a corresponding increase in the fraction of HD and PD patients with PTH levels being maintained within the 16-72 pmol/L range. The fraction of patients with PTH above range $(>72 \mathrm{pmol} / \mathrm{L})$ increased from $15.2 \%$ in 2006 to $17.9 \%$ in 2016 in those receiving HD but was almost unchanged in those receiving PD during the same period (figure 8.31).

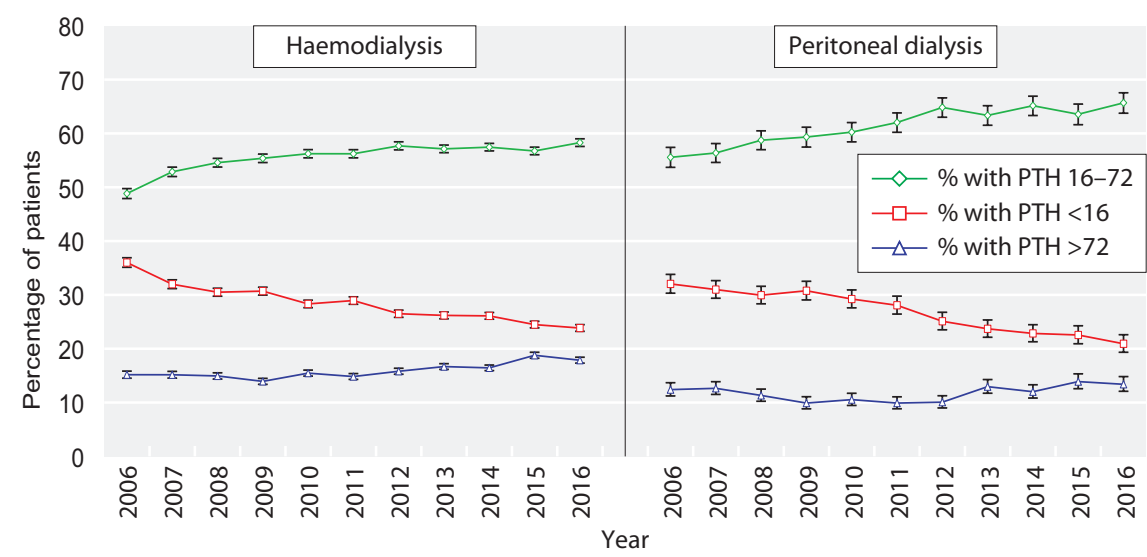

Fig. 8.31. Longitudinal change in percentage of patients with PTH within range (16$72 \mathrm{pmol} / \mathrm{L}$ ) by dialysis modality $2006-2016$ 